\title{
PRESERVASI KOLEKSI KASET VIDEO LANGKA \\ KE DALAM BENTUK DIGITAL MELALUI \\ PROSES ALIH MEDIA \\ (Studi Kasus di UPT Perpustakaan ISI Surakarta)
}

\section{LAPORAN PENELITIAN PEMULA}

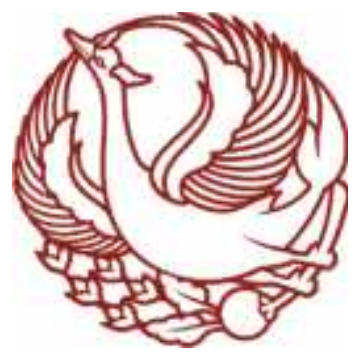

Peneliti :

Eko Sulistyo, S.Sn

NIP. 197211182006041001

Dibiayai dari DIPA ISI Surakarta sesuai dengan

Surat Perjanjian Penugasan Pelaksanaan Program Penelitian Pemula

Tahun Anggaran 2019

Nomor: 6842/IT6.1/LT/2019 tanggal 2 Mei 2019

INSTITUT SENI INDONESIA SURAKARTA

OKTOBER 2019 


\section{HAL AMAN PENGESAHAN}

Judul Penelitian

Preservasi Koleksi Kaset Video Langka Ke Dalam Bentuk Digital Melalui Proses Alih Media (Studi Kasus di UPT Perpustakaan ISI Surakarta)

\section{Pengusul ;}

a. Nama Lengkap

Eko Sulistyo, S.Sn.

b. NIP

197211182006041001

c. Jabatan Fungsional

d. Jabition struktural

c. Fakultay Jurecan

f. Alamat Institusi : UPT. Perpustakaan

g. Telp/ Faks/E-mail Kentingan Jebres Surakarta :0812-2648-976rekoalsskealgmail,com

Lama Penelitian Kescluruhan : 6 bulin

Panbinyaan DIPA

Rp. 10.000.000-(Sepuluk Juta Rupiah)

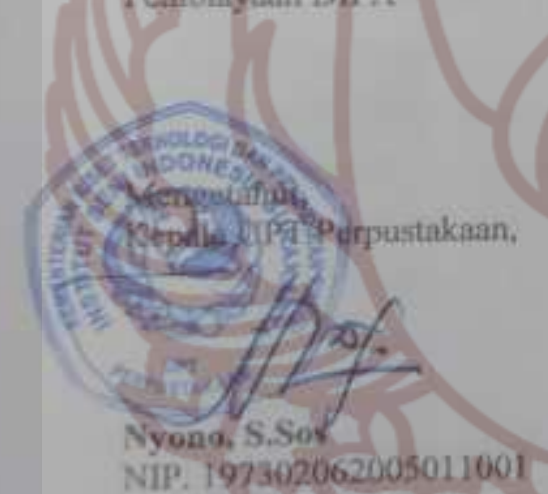

(2)

Surakarta, 30 Oktober 2019

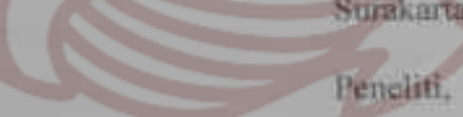

siifi.

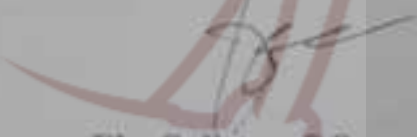

Eko Suistyo, S.Sn.

NiP. 1972 iा182006041001

ip. 93302062005011001

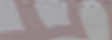




\section{DAFTAR ISI}

HALAMAN JUDUL .......................................................................... i

HALAMAN PENGESAHAN ..................................................................... ii

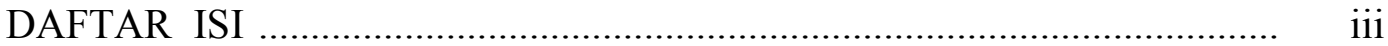

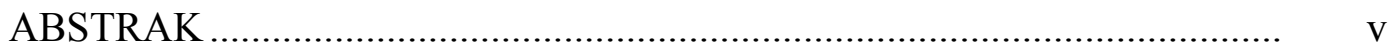

KATA PENGANTAR …............................................................ vi

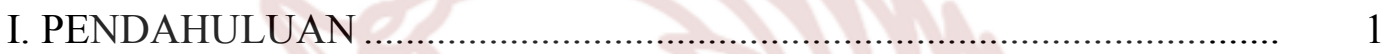

A. Latar Belakang Masalah ...................................................................... 1

B. Rumusan Masalah ............................................................................. 5

C. Tujuan Penelitian .................................................................................. 5

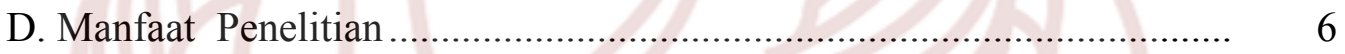

E. Luaran Penelitain ................................................................................... 6

II. TINJAUAN PUSTAKA DAN LANDASAN TEORI ............................. 7

A. Tinjauan Pustaka................................................................................ 7

B. Landasan Teori..................................................................................... 9

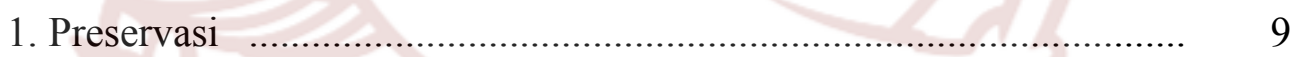

2. Kaset Video Langka .................................................................... $\quad 10$

3. Koleksi Digital ........................................................................... 12

4. Alih Media ................................................................................. 12

5. Tujuan Preservasi ......................................................................... 13

6. Fungsi Preservasi dan Konservasi ..................................................... 14

7. Unsur Perawatan dan Pelestarian ...................................................... 15

8. Pentingnya Preservasi Koleksi Digital ................................................ 16

9. Alasan Penggunaan Koleksi Digital .............................................. 17

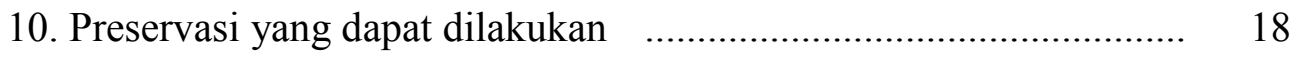

11. Memilih Teknik Preservasi Digital Yang Sesuai $\quad$.......................... 20 
III. METODOLOGI PENELITIAN _............................................................. 24

A. Jenis Penelitian ............................................................................. 24

B. Lokasi dan waktu penelitian ............................................................ 25

C. Teknik Pengumpulan Data ............................................................... 25

D. Tahapan Penelitian............................................................................... 27

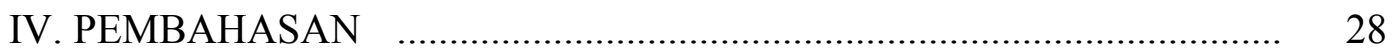

1. Observasi Koleksi di Perpustakaan ISI Surakarta ............................ 29

2. Menyusun Daftar Koleksi Video Langka ..................................... 36

3. Melakukan Koordinasi dengan Pustakawan Pelaksana Preservasi .... 42

4. Mempersiapkan Peralatan Preservasi .............................................. 44

5. Melaksanakan Proses Preservasi Melalui Alih Media ...................... 46

6. Hambatan Dalam Melakukan Preservasi Koleksi Kaset Video ....... 56

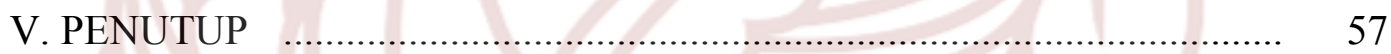

A. Kesimpulan .......................................................................... 57

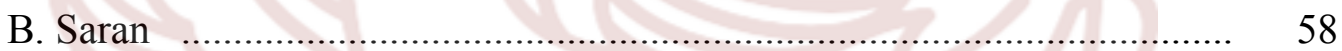

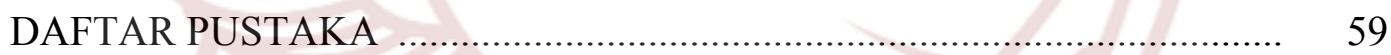

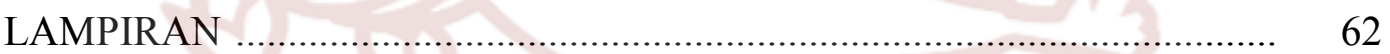




\begin{abstract}
ABSTRAK
Penelitian ini berjudul "Preservasi Koleksi Kaset Video Langka Ke Dalam Bentuk Digital Melalui Proses Alih Media (Studi Kasus di UPT Perpustakaan ISI Surakarta)". Penelitian ini bertujuan untuk mengetahui proses alih media koleksi kaset video ke dalam bentuk digital sebagai preservasi dan untuk mengetahui preservasi kaset video menggunakan salah satu software. Penelitian ini meruapakan penelitian kualitatif, dengan metode pengumpulan data melalui observasi, studi literartur dan dokumen. Selain menggunakan metode kualitatif, peneliti juga menggunakan metode partisipatori untuk melakukan preservasi digitalisasi, para pustakawan akan terlibat langsung dan turut dalam merencanakan proses preservasi yang didasarkan pada analisis sosial atau problem di lapangan. Hal ini merupakan cara preservasi yang berbeda, karena obyek yang menjadi kajian / yang akan dialihmediakan yaitu kaset video langka yang terdapat di Perpustakaan ISI Surakarta. Proses preservasi memerlukan penanganan yang khusus, harus melalui tahapan-tahapan preservasi, tahapan pra alih media yang biasanya dilakukan persiapan, antara lain: 1) Mempersiapkan daftar koleksi kaset video yang akan dipreservasi 2) Memilih koleksi yang diprioritaskan atau yang diutamakan yang sangat mendesak sebagai media pembelajaran di ISI Surakarta. 3) Memilih sumber daya manusia yang ahli di bidang preservasi. 4) Diperlukan peralatan yang lebih baik khususnya pada komputer dengan spesifikasi yang tinggi 5) Persiapan Infrasruktur. Strategi preservasi yang dilakukan oleh UPT Perpustakaan ISI Surakarta adalah dengan cara alih media dari koleksi kaset video ke dalam bentuk digital, alih media ini terdiri dari 9 tahapan dan menggunakan Software VEGAS Pro 16.0. Adapun tahapan-tahapan dalam alih media kaset video adalah sebagai berikut: 1) Membuka program/software VEGAS Pro 16.0. 2) Mencapture koleksi video yang dialih mediakan. 3) Pemilihan Format Video. 4) Proses Capture Video. 5) Proses Pembuatan Menu Editing. 6) Proses Import Data Video. 7) Pengambilan File Dokumen Video. 8) Proses Editing Video. 9) Proses Rendering Video.
\end{abstract}

Kata Kunci: Preservasi, Kaset, Video, Koleksi Langka, Alih Media. 


\section{KATA PENGANTAR}

Puji syukur Alhamdulillah sudah selayaknya menjadi ungkapan utama dalam mengantarkan laporan ini karena atas berkat, rahmat serta karunia Allah semata, penyusunan laporan penelitian Preservasi Koleksi Kaset Video Langka ke Dalam Bentuk Digital Melalui Proses Alih Media (Studi Kasus di UPT Perpustakaan ISI Surakarta) dapat berjalan sesuai yang telah direncanakan.

Di era globalisasi saat ini informasi sudah menjadi kebutuhan pokok bagi setiap manusia, dan informasi itu pula yang sering di gunakan manusia untuk berinteraksi satu sama lainnya. Dengan kecanggihan teknologi informasi saat ini segala bentuk informasi dapat di peroleh oleh siapa saja, kapan saja dan dimana saja tanpa batasan ruang dan waktu. Kebutuhan akan informasi pula yang menyebabkan perubahan bentuk organisasi dalam hidup bermasyarakat.

UPT Perpustakaan ISI Surakarta merupakan salah satu perpustakaan Perguruan Tinggi Seni yang memiliki koleksi bermacam-macam, diantara dalam bentuk kaset pita (analog), piringan hitam (PH), video, CD-VCD, DVD yang cukup banyak jumlahnya. Koleksi tersebut memiliki informasi yang tidak ternilai, karena berisi gending-gending tradisional, musik tradisi (etno), tari-tari tradisi, serta hasil dari penelitian mahasiswa maupun dosen. Apabila koleksi tersebut tidak dijaga, dikelola dan dirawat maka akan mengalami kerusakan. Preservasi Koleksi Kaset Video Langka Ke Dalam Bentuk Digital Melalui Proses Alih Media adalah alternatif yang bisa diambil oleh perpustakaan guna melestarikan koleksi digitalnya. Namun demikian perlu perencanaan yang matang dan mengetahui segala kelebihan dan kekurangan dari cara-cara tersebut sehingga dapat disesuaikan dengan keadaan perpustakaan tersebut.

Dengan terlaksananya penelitian ini kami mengucapan terima kasih dan penghargaan setinggi-tingginya disampaikan kepada Direktorat Riset dan Pengabdian Kepada Masyarakat, Direktorat Jendral Pendidikan Tinggi, Kementrian Riset, Teknologi dan Pendidikan Tinggi, yang telah mendanai penelitian ini melalui DIPA Institut Seni Indonesia (ISI) Surakarta. Kepada Ketua Pengabdian kepada 
Masyarakat, dan Pengembangan Pendidikan (LPPMPP) ISI Surakarta beserta reviewer dan staf atas kesempatan yang telah diberikan bagi usulan penelitian pemula ini.

Penyusunan laporan penelitian ini tidak akan berjalan sesuai rencana tanpa adanya kontribusi dari berbagai pihak, baik berupa pemikiran, saran, kritik, bantuan dana, maupun dorongan moral-spiritual. Oleh karena itu, dalam kesempatan ini peneliti sampaikan terima kasih kepada: Rektor ISI Surakarta, Wakil Rektor I ISI Surakarta, dan Kepala UPT Perpustakaan ISI Surakarta, atas izin dan kemudahan penggunaan berbagai fasilitas serta peralatan untuk mendukung penelitian ini. Ucapan terima kasih dan penghargaan yang setinggi-tingginya juga layak disampaikan kepada segenap rekan sejawat pustakawan ISI Surakarta yang telah memberikan dorongan semangat dan kerja-samanya. Semoga budi baik yang telah diberikan oleh semua pihak tersebut serta berbagai pihak yang tidak dapat disebut satu per satu, yang telah membantu proses penelitian ini, menjadi catatan amal kebajikan yang akan memberkahi kehi-dupan masing-masing.

Akhir kata kami menyadari, seturut pepatah tiada gading yang tak retak, laporan penelitian ini masih jauh dari sempurna untuk itu, sangat diharapkan kritik dan saran dari berbagai pihak. Selebihnya di luar segala keterbatasan yang ada, kami berharap semoga tulisan ini dapat diambil manfaatnya bagi pengembangan pengetahuan, khususnya di bidang kepustakawanan.

Surakarta, Oktober 2019

Peneliti 


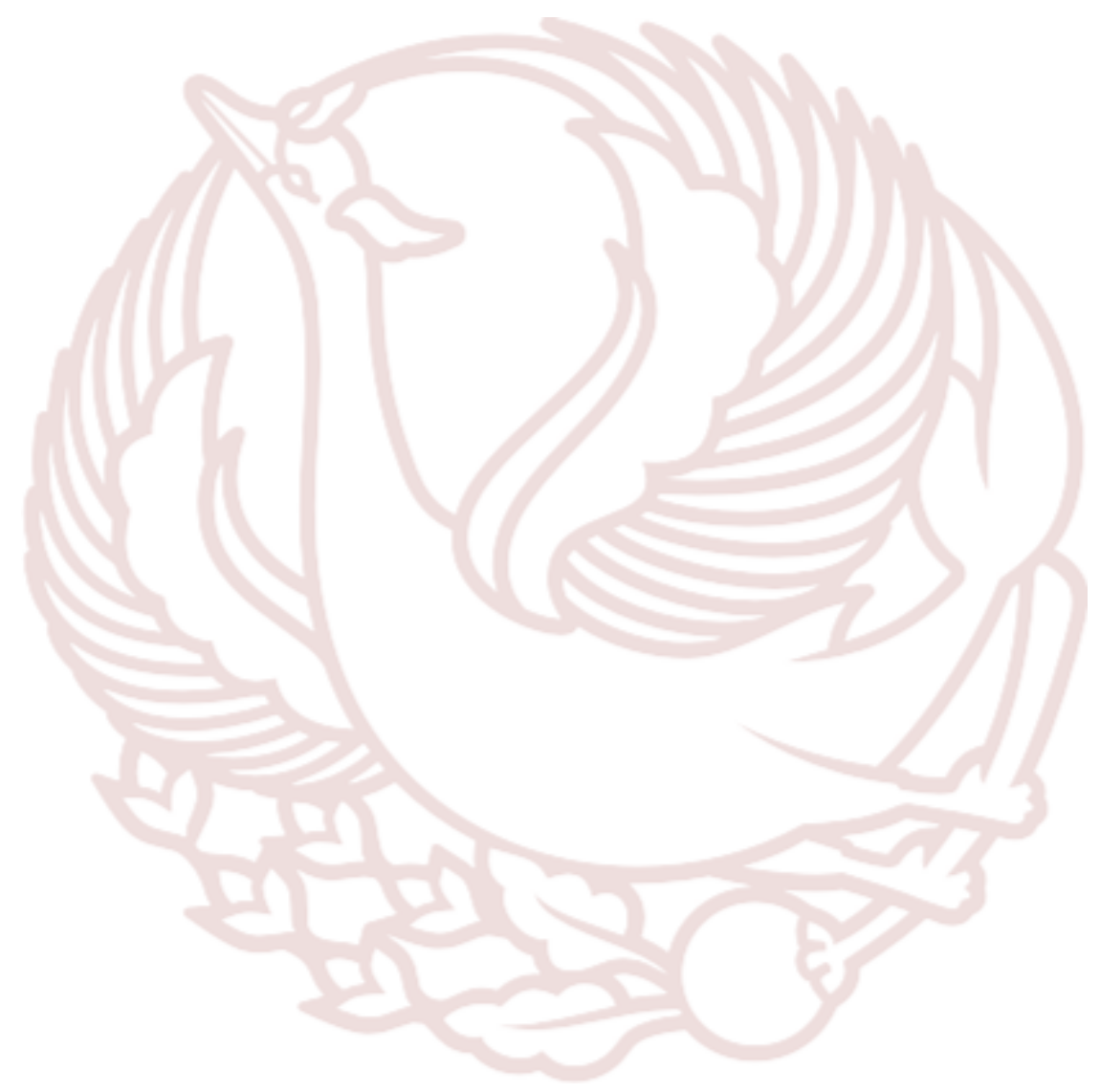




\section{BAB I \\ PENDAHULUAN}

\section{A. Latar Belakang Masalah}

Bahan pustaka merupakan salah satu bagian terpenting dalam sebuah sistem perpustakaan. Pada umumnya perpustakaan memiliki koleksi bahan pustaka yang terbuat dari kertas yang merupakan bahan yang mudah robek dan terkena noda. Selain kertas perpustakaan juga memiliki koleksi yang berupa non buku, antara lain: kaset audio, kaset video, piringan hitam, CD dan lain-lain. Cepat atau lambat proses kerusakan tergantung pada mutu bahan, iklim daerah serta perawatannya menyebabkan bahan pustaka harus dilestarikan

Pelestarian bahan pustaka tidak hanya menyangkut pelestarian dalam bidang fisik, tetapi juga pelestarian dalam bidang informasi yang terkandung di dalamnya. Pelestarian ini dilakukan agar bahan pustaka dapat dipakai lebih lama dan bisa menjangkau lebih banyak pemustaka di perpustakaan. Sehingga pemustaka dengan senang hati akan berkunjung ke perpustakaan karena bahan pustaka yang tersedia terawat dengan baik. Pelestarian dan perawatan bahan pustaka dilingkungan perpustakaan merupakan kegiatan yang perlu mendapat perhatian. Tidak semua jenis perpustakaan harus melakukan pelestarian koleksi yang dimilikinya, akan tetapi perawatan bahan pustaka menjadi kegiatan yang perlu dilakukan oleh semua jenis perpustakaan. Perawatan terhadap bahan pustaka perlu dilakukan karena untuk menjamin bahan koleksi yang dimiliki perpustakaan agar selalu siap untuk digunakan pemakai oleh setiap saat (Darmono, 2001:70).

Di era globalisasi saat ini informasi sudah menjadi kebutuhan pokok bagi setiap manusia, dan informasi itu pula yang sering di gunakan manusia untuk berinteraksi satu sama lainnya. Dengan kecanggihan teknologi informasi saat ini segala bentuk informasi dapat di peroleh oleh siapa saja, kapan saja dan dimana saja tanpa batasan ruang dan waktu. Kebutuhan akan 
informasi pula yang menyebabkan perubahan bentuk organisasi dalam hidup bermasyarakat.

Alih media perpustakaan biasa dilakukan pada bahan pustaka yang bernilai sejarah, naskah kuno, buku langka atau bahan pustaka yang memiliki kondisi fisik yang sudah rapuh. Namun proses alih media konvensional dengan melakukan fotokopi biasanya akan semakin merusak fisik bahan pustaka sehingga perpustakaan harus mempunyai kebijakan membuat salinan dalam bentuk alih media berbentuk digital guna melestarikan informasi bahan pustaka tersebut.

Selain itu, alih media acapkali berpotensi menimbulkan pelanggaran terhadap hak cipta namun perlu diingat bahwa perpustakaan sebagai lembaga publik tidak hanya memberi layanan jasa informasi tetapi juga mempunyai tugas melestarikan hasil ciptaan manusia agar hasil karya cipta tersebut dapat diberdayakan sepanjang masa. Guna melestarikan nilai informasi yang terkandung dalam bahan pustaka maka perpustakaan harus dapat menjaga dan melindungi hak cipta seseorang dengan menerapkan kebijakan yang berpihak pada kepentingan publik serta tetap menghormati hak-hak intelektual individu dan masyarakat.

Perpustakaan merupakan salah satu pusat informasi yang berkembang pada era globalisasi seperti saat ini. Pada UU no. 43 tahun 2007, dijelaskan bahwa setiap instansi diwajibkan harus memiliki perpustakaan, melihat fenomena tersebut dapat diartikan bahwa perpustakaan sangat penting sebagai pusat menyedia informasi yang cepat, tepat dan akurat. Dalam memenuhi kebutuhan akan informasi yang menunjang, perpustakaan membutuhkan dukungan dari beberapa faktor diantaranya adalah sarana dan prasarana, koleksi dan sumber daya manusia. Supaya sumber informasi yang disediakan oleh perpustakaan dapat dimanfaatkan selalu setiap saat, perpustakaan harus memiliki cara untuk menyimpan dan melestarikan koleksi tersebut. Perpustakaan tidak hanya menyediakan koleksi terbaru namun juga harus melestarikan koleksi lama yang masih mengandung nilai informasi yang berguna sebagai sumber referensi/rujukan. 
Perkembangan internet dipandang oleh pustakawan dan pendidik sebagai suatu potensi yang bagus untuk mengembangkan web sebagai ruang informasi yang dapat dimanfaatkan dunia pendidikan. Pustakawan memandang bahwa internet sebagai suatu "rumah baru" untuk koleksi digital sehingga membentuk perpustakaan digital, sedangkan dalam pandangan pendidik adalah memungkinkannya dibentuk suatu ruang kelas di web atau dengan kata lain membangun suatu lingkungan pembelajaran secara virtual, Sarah (1999:344-352).

Era digital berkembang ditandai dengan munculnya tiga teknologi, yaitu: komputer, komunikasi dan multimedia. Perkembangan ketiga teknologi telah membuat muatan informasi atau pesan dalam komunikasi tidak lagi hanya berupa teks, angka, gambar saja, melainkan dapat berupa suara, atau bahkan berupa gambar yang bergerak (film, video) tak ubahnya menikmati siaran langsung seperti melalui stasiun radio atau siaran televisi. Bahkan dengan perkembangan teknologi yang mampu memampatkan ukuran data atau informasi untuk kemudian diurai kembali setelah sampai di tujuan, membuat transfer informasi dan data dapat menjadi lebih cepat. Selain mempercepat proses dalam aktivitas sehari-hari, format data digital juga mempermudah aktivitas pelayanan kepada masyarakat, Elvina (2010).

Perkembangan teknologi mampu memampatkan ukuran data atau informasi untuk kemudian diurai kembali setelah sampai di tujuan, membuat transfer informasi dan data dapat menjadi lebih cepat. Selain mempercepat proses dalam aktivitas sehari-hari, format data digital juga mempermudah aktivitas pelayanan kepada masyarakat. Namun dengan media tempat menyimpan informasi digital selalu mengalami degradasi dan bisa rusak tanpa pemberitahuan sama sekali. Perangkat keras dan lunak seringkali ketinggalan zaman tanpa kita sadari. Karena itu perlu diperhatikan manajamen daur hidup (lifecycle management) koleksi digital yang disimpan. Untuk itu diperlukan pelestarian terhadap koleksi digital ini, Daryono (2011).

Piagam UNESCO dibuka dengan definisi tentang digital heritage sebagai "cultural, educational, scientific and administrative resources, as 
well as technical, medical and other kinds of information created digitally, or converted into digital form from existing analogue resources" termasuk di dalamnya "texts, databases, still and moving images, audio, graphics, software and web pages". Piagam itu juga memperingatkan masyarakat tentang berbagai faktor yang dapat mengancam kelestarian produk digital, baik itu berupa perubahan teknologi perangkat keras dan lunak yang sangat cepat, mapun ketidakpastian dalam hal keaslian dan tanggungjawab kebenaran isinya. Secara khusus UNESCO “menegur" semua negara untuk menyiapkan perangkat hukum bagi upaya melindungi berkas-berkas digital yang amat penting itu. (http://portal.unesco.org/ci/en/ev)

Piagam UNESCO juga merupakan penegasan tentang betapa mengkuatirkannya kondisi kelimpahruahan digital saat ini, sehingga perlu SEGERA ada penelitian dan pengembangan dalam aspek berikut ini:

- Model dan strategi teknologi preservasi digital (emulasi, migrasi).

- Sistem penyimpanan dan metadata preservasi.

- Standar tentang kepastian hukum dan otoritas isi.

- Mekanisme kurator dan digitasi produk non-digital.

- Payung hukum untuk institusi presevasi digital tingkat nasional

UPT Perpustakaan ISI Surakarta merupakan salah satu perpustakaan Perguruan Tinggi Seni yang memiliki koleksi bermacam-macam, diantara dalam bentuk kaset pita (analog), piringan hitam (PH), video, CD-VCD, DVD yang cukup banyak jumlahnya. Koleksi tersebut memiliki informasi yang tidak ternilai, karena berisi gending-gending tradisional, musik tradisi (etno), tari-tari tradisi, serta hasil dari penelitian mahasiswa maupun dosen. Apabila koleksi tersebut tidak dijaga, dikelola dan dirawat maka akan mengalami kerusakan. 
Jumlah Koleksi Kaset Video

\begin{tabular}{|c|l|c|c|}
\hline No. & \multicolumn{1}{|c|}{ Jenis Koleksi } & Jumlah Koleksi & Satuan \\
\hline 1 & Kaset Audio & 8.045 & Eksemplar \\
\hline 2 & Piringan Audio & 370 & Eksemplar \\
\hline 3 & Kacet CD & 40 & Eksemplar \\
\hline 4 & Kaset Video & 896 & Eksemplar \\
\hline 5 & Kaset VCD & 568 & Eksemplar \\
\hline & Jumlah : & 9.919 & Eksemplar \\
\hline
\end{tabular}

Sumber : Koleksi UPT Perpustakaan ISI Surakarta, 2018.

Preservasi Koleksi Kaset Video Langka Ke Dalam Bentuk Digital Melalui Proses Alih Media adalah alternatif yang bisa diambil oleh perpustakaan guna melestarikan koleksi digitalnya. Namun demikian perlu perencanaan yang matang dan mengetahui segala kelebihan dan kekurangan dari cara-cara tersebut sehingga dapat disesuaikan dengan keadaan perpustakaan tersebut.

\section{B. Rumusan Masalah}

Berdasarkan latar belakang masalah di atas, maka yang menjadi rumusan masalah yaitu bagaikamanakah proses alih media koleksi kaset video langka ke dalam bentuk digital sebagai preservasi koleksi?

\section{Tujuan Penelitian}

Penelitian ini mempunyai tujuan sebagai berikut :

1. Untuk mengetahui proses alih media koleksi kaset video ke dalam bentuk digital sebagai preservasi.

2. Untuk mengetahui preservasi kaset video menggunakan salah satu software. 


\section{Manfaat Penelitian}

Penelitian ini mempunyai manfaat sebagai berikut :

1. Dapat menambah pengetahuan tentang proses alih media koleksi kaset video langka ke dalam bentuk digital sebagai preservasi.

2. Dapat memberikan sumbangan yang lebih berarti mengenai preservasi kaset video langka menggunakan salah satu software di Perpustakaan ISI Surakarta.

\section{E. Luaran Penelitian}

Dalam penelitian Presevasi Koleksi Kaset Video Langka Ke Dalam Bentuk Digital Melalui Proses Alih Media (Studi Kasus di UPT Perpustakaan ISI Surakarta) menghasilkan luaran berupa:

1. Naskah publikasi, artikel jurnal ilmiah yang dipublikasikan.

2. Hasil penelitian yang dibuat makalahdan dipresentasikan dalam seminar

3. HKI 


\section{BAB II \\ TINJAUAN PUSTAKA DAN LANDASAN TEORI}

\section{A. Tinjaun Pustaka}

Penelitian tentang preservasi koleksi pernah dilakukan oleh beberapa orang yang pertama adalah penelitian dari Nurjannah (2014) dengan judul: “Preservasi dan Konservasi Bahan Pustaka dan Arsip Pasca Tsunami di Badan Arsip dan Perpustakaan Aceh”. Tesis Magister, Program Studi Interdiciplinary Islamic Studies Konsentrasi Ilmu Perpustakaan dan Informasi UIN Sunan Kalijaga Yogyakarta, 2014. Latar belakang penelitian tentang proses Preservasi dan Konservasi Bahan Pustaka dan Arsip Pasca Tsunami di Badan Arsip dan Perpustakaan Aceh Rumusan masalahnya adalah bagaimana kebijakan dan proses serta teknik preservasi dan konservasi bahan pustaka dan Arsip pasca tsunami di Badan Arsip dan Perpustakaan Aceh. Penelitian ini bertujuan untuk mengetahui kebijakan dan proses serta teknik preservasi dan konservasi bahan pustaka dan Arsip pasca tsunami di Badan Arsip dan Perpustakaan Aceh. Penelitian ini merupakan penelitian lapangan (Field Research) yang bersifat kualitatif serta menggunakan metode deskriptif. Sedangkan teknik pengumpulan data menggunakan purposive sampling, yaitu teknik pengambilan sampling yang berdasarkan pada karakteristik tertentu yang dianggap mempunyai sangkut paut dengan apa yang diteliti melalui dokumen dan wawancara yang mendalam. Proses analisis data menggunakan teori Miles dan Hubermen, yaitu dengan meredusi data; memfokuskan pada tema penelitian,menyajikan data; menjelaskan berdasarkan wawancara dan dokumentasi, serta menyimpulkan analisis. Sampel penelitian dalam penelitian ini yaitu seluruh bahan pustaka dan arsip di Badan Arsip dan Perpustakaan Aceh. Artinya setiap data dari hasil wawancara, observasi dan data dokumen dimasukkan dalam penulisan ini dan kemudian dianalisa melalui deskriptif analisis yaitu menguraikan data-data yang ada sehingga dapat diambil suatu kesimpulan.Dalam penanganan bahan pustaka dan arsip 
pasca bencana gempa bumi dan tsunami Aceh memberikan pelajaran bagi kita dalam segala aspek penanganan. Bagaimana kita harus melakukan investigasi, tanggap darurat, rehabilitasi, dan rekonstruksi terhadap bahan pustaka dan kearsipan. Penanganan ini tidak bisa dilakukan sendiri melainkan harus menggalang kerjasama dengan lembaga lain. Baik itu dengan lembaga pemerintah (pusat maupun daerah), NGO (nasional maupun asing) serta dengan lembaga internasional maupun negara lain.

Penelitian kedua, yaitu penelitian yang dilakukan oleh Niputu Wahyu Candra Widhiandari pada tahun 2012.10 Penelitian ini berjudul "Preservasi Naskah Lantar di Perpustakaan Indonesia. Penelitian ini bertujuan untuk mengindenfikasi kondisi fisik koleksi lontar dan mengkaitkannya dengan faktorfaktor pengrusak lontar serta memaparkan kegiatan preservasi koleksi di perpustakaan Universitas Indonesia. Penelitian ini meruapakan penelitian kualitatif, dengan metode pengumpulan data melalui observasi, wawancara dan dokumen. Hal ini merupakan cara preservasi dan konservasi yang berbeda, yaitu diteliti tentang naskah lontar yang rusak, naskah lontar yang dimakan rayap dan cara proses prservasi itu bagaimana, serta tempat penelitian dan waktu penelitian yang berbeda pula. Dalam hal ini ada persamaan dengan penelitian yang peneliti lakukan juga memiliki perbedaan dalam waktu dan tempat penelitian serta dalam fokus kajian mengenai preservasi dan prservasi tentang koleksi bahan pustaka.

Penelitian ketiga, dilakukan oleh Alfiah Aprilyani.9 Dalam penelitian ini peneliti mengkaji tentang pelestarian bahan pustaka dalam preservasi dan konservasi. Penelitian tersebut dilakukan di Badan Perpustakaan dan Arsip Daerah Istimewa Yogyakarta (DIY). Tujuan dari penelitian ini adalah menjelaskan bagaimana peran pelestarian bahan pustaka dalam presrvasi dan konservasi di Badan Arsip dan Perpustakaan Daerah Istimewa Yogyakarta (DIY). Jeneis penelitian yang digunakan adalah penelitian bersifat deskriptif kualitatif. Metode pengumpulan data dilakukan melalui observasi, wawancara, dan dokumentasi. Dari hasil penelitian dan pembahasan maka kesimpulannya adalah preservasi dan konservasi sangat penting dilakukan demi menjaga 
kelestarian bahan pustaka di Badan Arsip dan Perpustakaan Daerah Istimewa Yogyakarta (DIY). Beberapa indikator yang dapat disimpulkan tentang peran pelestarian adalah tindakan preventif, kedua tindakan kuratif. Peran pelestarian bahan pustaka dalam preservasi dan konservasi secara preventif meliputi kegiatan pemeliharaan bahan pustaka yang berbagi kebeberapa bagian yaitu membersihkan rak dengan Vacum cleaner, merapikan bahan pustaka dan memberikan bahan pengusir serangga (kapur barus), sedangkan kuratif yaitu fumigasi, penyampulan buku, pembuatan kotak pelindung, alih huruf, alih bahasa dan alih media.

Berdasarkan tinjauan pustaka diatas, penelitian Presevasi Koleksi Kaset Video Langka Ke Dalam Bentuk Digital Melalui Proses Alih Media (Studi Kasus di UPT Perpustakaan ISI Surakarta) sedikit berbeda dengan penelitian sebelumnya dan membuktikan bahwa penelitian yang akan peneliti lakukan belum pernah diteliti sebelumnya, khususnya di Kota Surakarta. Beberapa penelitian sejenis yang pernah dilakukan peneliti di atas masing-masing memiliki perbedaan dalam hal variabel, subyek, metode, tempat serta waktu penelitian.

\section{B. Landasan Teori}

Preservasi merupakan kegiatan yang terencana dan dikelola untuk memastikan bahwa suatu aset, baik itu kekayaan sumber daya alam, ataupun benda-benda bersejarah agar tetap terjaga dan dapat dipakai selama mungkin. Dalam kaitannya preservasi bahan pustaka, defenisi preservasi kurang lebih memiliki makna yang sama namun dalam konteks yang berbeda. Preservasi bahan pustaka merupakan suatu usaha yang dilakukan secara terencana dan terkelola untuk memastikan bahan-bahan pustaka dapat terpelihara dengan baik agar tetap dapat dipakai selama mungkin.

1. Preservasi

Pengertian Preservasi Bahan Pustaka Menurut Sutarno N.S (2008: 174)

"Preservasi adalah suatu kegiatan dibidang perpustakaan untuk memelihara dan merawat koleksi bahan pustaka”. Menurut Lasa (2009: 287) “ Preservasi 
yaitu semua unsur pengelolaan, keuangan, penyimpanan, alat-alat bantu, ketenagakerjaan, maupun metode yang digunakan untuk melestarikan bahan pustaka, arsip, maupun informasi yang dikandungnya".

Preservasi adalah kegiatan yang terencana dan terkelola untuk memastikan agar koleksi perpustakaan dapat terus dipakai selama mungkin. Pada dasarnya preservasi yaitu upaya untuk memastikan agar semua bahan koleksi cetak maupun non cetak pada suatu perpustakaan bisa tahan lama dan tidak cepat rusak. Pelestarian (Preservation) mencakup semua aspek usaha melestarikan bahan pustaka dan arsip, termasuk didalamnya kebijakan pengolahan, metode dan teknik, sumber daya manusia, dan penyimpanannya, Ibrahim (2014: 92).

Preservasi adalah upaya pelestarian yang sifatnya menjadi koleksi untuk tetap utuh seperti kondisinya saat ini. Kondisi yang rusak dalam kebijakan preservasi tidak akan diperbaiki, namun hanya sampai kepada upaya menjaga agar kerusakan koleksi tersebut tidak semakin bertambah. Preservasi bahan pustaka tidak hanya terbatas pada pelestarian fisik bahan pustaka, namun pelestarian bahan pustaka haru memperhatikan pentingnya nilai informasi yang terkandung pada sebuah bahan pustaka.

Dari uraian diatas, dapat diketahui bahwa preservasi bukan hanya kegiatan untuk merawat, melestarikan, dan memperbaiki atau melestarikan saja, tetapi didalamnya juga terdapat unsur pengelolaan dalam hal penggunaan teknik, metode atau proses, keuangan, ketenagakerjaan, dan lain-lain. Pada dasarnya preservasi atau pelestarian bertujuan untuk melestarikan informasi yang terkandung dalam bahan pustaka agar dapat dipertahankan keutuhannya.

2. Kaset Video Langka

a. Kaset Video

Menurut Kamus Besar bahasa Indonesia (2017:1843) video adalah 1) bagian yang memancarkan gambar pada pesawat televise; 2) rekaman gambar hidup atau program televise untuk ditayangkan lewat pesawat televise. Tim Redaksi Kamus Besar Bahasa Indonesia, Kamus Besar 
Bahasa Indonesia, Ed. Ke-4, Jakarta : badang Pengembangan dan Pembinaan Bahasa Kementerian Pendidikan dan Kebudayaan, 2017.

Sedangkan menurut Dagung dalam Ervina (2018:19), video merupakan tek pesawat yang memancarkan gambar pada pesawat televisi, alat merekam gambar hidup dan bisa ditayangkan kembali lewat layar televise.

Daryanto dalam Ervina (2018:20), mengungkapkan beberapa manfaat dari video, antara lain: 1) Video dapat merekam peristiwa yang terjadi secara cepat dan praktis dan dapat menampilkan tayangan atau hasil pengambilan film secara cepat pula tanpa proses lebih lanjut. 2) Video dapat memperbesar atau memperkecil ukuran dan waktu dari suatu proses. 3) Video dapat diputar ulang. 4) Kaset film sangat berukuran praktis. 5) Video dapat ditampilkan di televisi yang besar maupun kecil. 6) Kaset video dapat digerakkan dengan putaran lambat atau cepat.

b. Koleksi Langka

Pengertian koleksi langka Ada beberapa pengertian tentang koleksi langka yaitu:

1) Menurut beberapa pakar di Indonesia Koleksi langka adalah buku yang sudah sangat sulit didapatkan di pasaran, walau buku tersebut dicetak masih baru, karena terbatasnya eksemplar (http://digilib.pnri.go.id)

2) Menurut Susanto Zuhdi koleksi langka adalah koleksi yang sudah tidak terbit lagi, sekalipun usianya belum begitu lama. (http://www. perpusnas.go.id)

3) Sedangkan menurut Badan Perpustakaan dan arsip Daeah Propinsi DIY sendiri mendefinisikan koleksi langka, pustaka langka atau disebut juga antique books adalah suatu jenis koleksi yang memiliki ciri-ciri yang tidak diterbitkan lagi, sudah tidak beredar di pasaran, susah untuk mendapatkannya, mempunyai kandungan informasi yang tetap, memiliki informasi kesejarahan. (http://www.badanperpusda-diy.go.id). 
Jadi koleksi langka adalah koleksi yang sulit ditemukan dipasaran karena sudah tidak diterbitkan lagi. Koleksi buku yang masih baru dapat dikatakan koleksi langka karena jumlah eksemplar yang terbatas.

Dari keterangan di atas bisa disimpulkan bahwa pengertian kaset video langka yaitu rekaman gambar hidup atau program televise untuk ditayangkan lewat pesawat televise atau tek pesawat yang memancarkan gambar pada pesawat televise atau visual yang menampilkan gerak yang sudah sangat sulit didapatkan di pasaran, tidak diterbitkan dan sudah susah ditemukan alat pemutarnya.

\section{Koleksi Digital}

"A collection of library or archival materials converted to machine-re adable format for preservation or to provide electronic access (example: The Papers of Thomas Jefferson: Digital Edition, a project of the University of Virginia Library. Also, library materials produced in electronic formats, including e-zines, e-journals, e-books, reference works published online and on CD-ROM, bibliographic databases, and other Web-based resources. In the United States, the Digital Library Federation is developing standards and best_ practices for digital collections and network access. In the meantime, the National Information Standards Organization (NISO) has published A Framework of Guidance for Building Good Digital Collections (2007)”.

Artinya, koleksi digital adalah koleksi perpustakaan atau arsipyang dikonversikan ke dalam format yang dapat dibaca oleh mesih (machine redeable format) untuk tujuan pelestarian atau penyediaan akses elektronik. Juga termasuk materi yang diproduksi dalam bentuk elektronik, mencakup e-zines, e-journals, e-books, karya referensi yang dipublikasikan secara online dan dalam CD-ROM, database, bibliografi, dan sumber-sumber berbasis WEB lainnya. Reitz (2002).

4. Alih Media

Pengertian alih media sebagaimana diatur pada PP. Nomor 88 Tahun 1999 Tentang Tata Cara Pengalihan Dokumen Perusahaan ke dalam mikrofilm atau media lainnya adalah alih media ke microfilm san media lain yang buka kertas dengan keamanan tinggi seperti misalnya CD Rom dan 
Worm. Pengalihmediaan merupakan kegiatan pemindahan informasi dari bentuk tekstual ke elektronik, tanpa mengurangi isi informasinya, dengan catatan media baru yang digunakan menjamin bahwa hasilnya lebih efisien dan efektif. Alih media atau alih bentuk merupakan salah satu model usaha pelesteraian yang dilakukan dengan merubah bentuk atau media informasi dari bentuk kertas (tercetak) ke dalam bentuk lain seperti bentuk mikro atau video disk atau bentuk pita magnetik lainnya.

5. Tujuan Preservasi

Tujuan Preservasi dan Konservasi Bahan Pustaka Tujuan utama preservasi dan konservasi bahan pustaka adalah mengusahakan agar koleksi bahan pustaka selalu sedia dan siap pakai, hal ini dapat dilakukan dengan melestarikan bentuk fisik bahan pustaka, melestarikan kandungan informasi kedalam media lain (alih media) seperti microfilm, mikrofish, foto reproduksi, dan fotokopy, atau melestarikan kedua-duanya, yaitu bentuk fisik dan kandungan informasi.

Menurut Ibrahim (2014:37) ada beberapa tujuan yang harus dicapai terkait dengan kegiatan kerja preservasi dan konservasi bahan pustaka di perpustakaan:

a. Menyelamatkan nilai informasi yang terkandung didalam setiap bahan pustaka.

b. Menyelamatkan bentuk fisik bahan pustaka.

c. Mengatasi kendala kekurangan ruang (space).

d. Mempercepat proses temu balik atau penelusuran dan perolehan informasi.

e. Menjaga keindahan dan kerapian bahan pustaka.

Dengan kegiatan preservasi dan konservasi bahan pustaka yang baik, diharapkan bahan pustaka dapat berumur dengan panjang,membantu melaksanakan kegiatan pelestarian bahan pustaka,menunjang layanan jasa perpustakaan dan layanan informasi dalam upaya penyediaan koleksi bahan pustaka dalam keadaan bersih, utuh layak serta membantu menyelamatkan fisik bahan pustaka dan kandungan informasi yang terdapat didalamnya. 


\section{Fungsi Preservasi dan Konservasi}

Fungsi preservasi dan konservasi adalah untuk menjaga agar koleksi perpustakaan tidak diganggu oleh tangan jahil, serangga yang iseng, atau jamur yang merajalela pada buku-buku yang ditempatkan pada ruang yang lembab. Preservasi adalah sebuah kegiatan yang terencana dan terkelola untuk memastikan bahan-bahan pustaka dapat terpelihara dengan baik agar dapat tetap di gunakan selama mungkin. Sedangkan konservasi adalah sebuah usaha untuk mempertahankan (pengawetan) yang memiliki kebijakan khusus untuk mempertahankan bahan pustaka.

Fungsi pelestarian menurut Almah (2012:166) ialah menjaga agar koleksi perpustakaan tidak diganggu serangga, atau jamur pada buku-buku yang ditempatkan diruang yang lembab. Pelestarian bahan pustaka memiliki beberapa fungsi sebagai berikut:

a) Fungsi melindungi: bahan pustaka dilindungi dari serangga, manusia, jamur, panas matahari, air, dan sebagainya. Dengan pelestarian yang baik serangga dan binatang kecil tidak akan dapat menyentuh dokumen.

b) Fungsi pengawetan: dengan dirawat baik-baik, bahan pustaka menjadi awet, bisa lebih lama dipakai, dan diharapkan banyak pemustaka dapat menggunakan bahan pustaka tersebut.

c) Fungsi kesehatan: dengan pelestarian dan perawatan yang baik, bahan pustaka menjadi bersih, bebas dari debu, jamur, sumber dan sarang berbagai penyakit, sehingga pemustaka maupun pustakawan menjadi tetap sehat.

d) Fungsi pendidikan: pemustaka dan pustakawan sendiri harus belajar bagaimana cara memakai dan merawat dokumen. Mereka harus menjaga disiplin, tidak mengotori bahan pustaka maupun ruangan perpustakaan.

e) Fungsi sosial: pelestarian tidak bisa dikerjakan oleh seorang diri. Pustakawan harus mengikut sertakan pemustaka untuk tetap merawat bahan pustaka dan perpustakaan. 
f) Fungsi keindahan: dengan pelestarian yang baik, penataan bahan pustaka yang rapih, perpustakaan tampak menjadi makin indah, sehingga menambah daya tarik bagi pemustaka.

Berdasarkan uraian diatas dapat diketahui bahwa, setiap perpustakaan sudah seharusnya melakukan kegiatan preservasi dan konservasi bahan pustaka agar bahan pustaka selalu dapat bertahan lebih lama dan dapat digunakan dalam jangka waktu yang lama, serta bahan pustaka yang tersedia dalam keadaan baik, menarik dan layak dibaca oleh para pengunjung perpustakaan karena bahan pustaka yang sudah rusak atau usang, kurang menyenangkan bagi para pemakai dan kurang menarik saat dibaca.

\section{Unsur Perawatan dan Pelestarian}

Bahan pustaka meruapakan unsur penting di dalam perpustakaan, sehingga kita harus melestarikannya. Pelestarian disini adalah mengusahakan agar bahan pustaka tidak cepat mengalami kerusakan. Menurut Sutarno (2004:3) “ Pengelolaan pelestarian bahan pustaka melibatkan berbagai komponen seperti sumber daya manusia, koleksi, peralatan, sarana dan prasarana, metode dan uang. Dalam konsep manajemen istilah tersebut dikenal dengan tools of manajement atau sarana manajemen".

Di dalam kegiatan perawatan dan pelestarian bahan pustaka banyak hal yang perlu diperhatikan. Salah satunya adalah unsur perawatan dan pelestarian bahan pustaka Menurut Martoadamodjo (1993:7) ada empat unsur yang penting yang perlu diperhatikan dalam perawatan dan pelestarian bahan pustaka, yaitu:

a) Manajemennya Perlu diperhatikan siapa yang jawab didalam pekerjaan pelestarian ini. Bagaimana prosedur pelestarian yang harus diikuti Bahan pustaka yang akan diperbaiki harus dicatat dengan baik, apa saja jenis kerusakannya, apa saja alat bahan kimia yang diperlukan, siapa dan bagaimana cara mengerjakannya.

b) Tenaga Kegiatan ini dilakukan oleh pustakawan atau memang orang yang ahli dan mempunyai keterampilan khusus dalam kegiatan ini 
sehingga kegiatan perawatan dan pelestarian bahan pustaka menjadi lancar dalam melakukan,perawatannya. 3.Laboratorium Setiap perpustaka an sebaiknya mempunyai ruangan khusus atau laboratorium yang khusus untuk merawat dan melestarikan bahan pustaka pustaka dan dilengkapi dengan peralatannya.

c) Dana Dana merupakan salah satu unsur yang terpenting bagi kegiatan perawatan dan pelestarian bahan pustaka, selalu diperlukannya dana yang tersusun dengan baik, sehingga kegiatan ini tidak akan mengalami kendala.

Unsur terpenting yang harus selalu di perhatikan dalam suatu kegiatan perawatan dan pelestarian bahan pustaka yaitu: manajemennya, tenaga yang memang ahli dalam kegiatan perawatan dan pelestarian bahan pustaka, laboratorium atau ruangan khusus dalam melakukan kegiatan paerawatan dan pelestarian bahan pustaka dan unsure dana. Jika tidak ada keempat unsur tersebut maka kegiatan perawatan dan pelsestarian bahan pustaka tidak akan berjalan dengan lancer dan optimal.

Berdasarkan uraian diatas maka dapat diketahui bahwa unsur pelestarian bahan pustaka meruapakan kegiatan pelestarian yang mencakup semua aspek usaha melestarikan semua bahan pustaka, yang termasuk didalamnya kebijakan pengolahan, sumberdaya manusia, metode dan dan tehnik penyimpanannya agar semua koleksi yang terdapat pada perpustakaan dapat dilestarikan dengan baik.

\section{Pentingnya Preservasi Koleksi Digital}

Kegiatan mentransfer informasi tercetak ke dalam bentuk digital seolah menjadi kesibukan utama perpustakaan besar Indonesia pada dasawarsa terakhir ini. Entah berapa ratus ribu bahkan jutaan gigabyte dokumen yang telah dijadikan digital di beberapa perpustakaan besar Indonesia. Tidak itu saja, mereka membuat pangkalan data referensi seperti katalog online, indeks subyek, dan sarana pencari informasi digital lainnya. Belum lagi jurnal elektronik, peta digital, data, atau dokumen kelabu (dokumen pemerintah yang tidak diterbitkan untuk umum) yang mereka 
koleksi dalam bentuk digital.

Dokumen digital rentan kerusakan dalam arti tidak dapat terbaca atau tak bisa diakses lagi. Barangkali keadaan ini bakal berubah menjadi bom waktu yang mengancam kelangsungan hidup perpustakaan digital.

Masalah kedua adalah perkembangan peranti keras diikuti peranti lunak yang berubah versi dengan cepatnya. Kemudian versi lama tidak bisa membaca informasi pada versi baru. Dunia digital Indonesia bergeming dengan ancaman tersebut dan kegiatan digitasi sepertinya mengalir begitu saja. Memang, selain kendala dalam hal mesin, dalam kasus tertentu dokumen digital terasa lebih mahal jika kita harus mencetaknya. Preservasi data atau dokumen digital menjadi hal penting karena kondisi berikut :

a. akumulasi data yang tak terkendali

b. kerusakan data tanpa sengaja

c. pengubahan data tanpa hak

d. kelangkaan metadata dan sistem dokumentasi

e. bentuk data elektronik yang tidak dapat dipreservasi

f. kelangkaan mekanisme untuk preservasi, Daryono (2011)

Masalah-masalah sekitar warisan digital sudah menjadi begitu kompleks sehingga sedang dilakukan berbagai upaya oleh kalangan perguruan tinggi, institusi, dan bisnis, untuk mengembangkan cara untuk melestarikan data yang diciptakan dalam bentuk digital. Tujuannya: agar data tersebut masih dapat dipahami puluhan dan ratusan tahun kedepan.

Di masa mendatang para pencari informasi minimal memerlukan metode-metode untuk mengekstraksi informasi dari media penyimpan yang sekarang sudah ada, dan yang kelak akan ada. Sarana macam ini pada suatu saat pasti tidak tersedia lagi atau tidak dapat dipakai lagi. Kapan misalnya, anda terakhir melihat suatu floppy disk drive? Suatu organisasi atau lembaga yang memperhatikan preservasi koleksi digitalnya akan selalu memindahkan informasi dari sistem lama ke yang lebih baru secara teratur.

\section{Alasan Penggunaan Koleksi Digital}

Perkembangan teknologi digital serta internet saat ini telah memberi 
kemudahan untuk melakukan akses serta mendistribusikan berbagai informasi dalam format digital. Beberapa faktor yang membuat data digital (seperti audio, citra, video dan text) banyak digunakan antara lain :

a. Mudah diduplikasi dan hasilnya sama dengan aslinya.

b. Murah untuk penduplikasian dan penyimpanan,

c. Mudah disimpan dan kemudian untuk diolah atau diproses lebih lanjut,

d. Serta mudah didistribusikan, baik dengan media disk maupun melalui jaringan seperti internet, Imma (2010)

10. Preservasi yang dapat dilakukan

Kerentanan media simpan adalah masalah yang perlu dicermati, walaupun teknologi ini selalu diperbarui. Penelitian terakhir tentang keawetan media magnetik menunjukkan pemakaiannya bisa 10-30 tahun jika ditangani dan disimpan dengan benar. Memang ada teknologi cakram optik yang menjanjikan produk yang tahan sampai 100 tahun, tapi ini masih dalam skala laboratorium dan belum teruji ketangguhannya jika diumbar di alam tropis dengan suhu dan kelembaban merupakan ancaman.

Sadar akan ancaman bom waktu pelestarian digital itu para pengelola informasi digital di negara maju seperti Amerika, berupaya menggalang kegiatan rutin untuk pemeliharaan aliran byte jangka panjang dan aksesibilitas kandungan intelektual sejalan dengan waktu dan perkembangan teknologi informasi. Pada November 2000, The Library of Congress harus bertindak cepat untuk mengarsipkan situs web yang berkaitan dengan Bill Clinton yang begitu mudah dibongkar orang. The Library of Congress sekarang ini malah menghabiskan US\$ 100 juta untuk melestarikan informasi digital pemerintah. Di Belanda proyek NEDLIB berusaha mencari jalan untuk mengarsipkan bahan legal deposit. Sementara itu, British Library menganggarkan 20 juta pound sterling untuk penyimpanan digital. Di Indonesia, terutama di lembaga milik pemerintah, masalah ini merupakan masalah besar karena ketidakberdayaan dalam bidang finansial. Beberapa langkah pelestarian digital yang bisa diterapkan dengan biaya terjangkau barangkali adalah pertama pengadaan peranti 
keras yang sesuai dengan spesifikasi disusul dengan prosedur operasi yang benar dan pemeliharaan yang rutin, Imma (2010)

Intinya, menjaga agar peranti keras dan lunak tetap bisa mengoperasikan data. Jika suatu ketika terjadi perkembangan versi yang tidak dapat dihindari bisa diadakan migrasi, atau memformat data kembali. Tentunya migrasi tanpa membuat skala prioritas, akan menjadi proses yang mahal karena memerlukan waktu dan tenaga yang tidak sedikit.

Salah contoh korban keusangan teknologi adalah floopy diskukuran 5.25 inch, dimana pada saat ini sudah jarang sekali ditemukan CPU komputer yang menyediakan drive untuk membaca floopy disk tersebut.

Menurut Pendit (2008:253) untuk menyelamatkan nilai informasi agar dapat dimanfaatkan dalam waktu yang relatif lebih lama lagi dan terhindar dari kerusakan terhadap koleksi digital atau elektronik, ada beberapa cara preservasi digital, antara lain :

a. Preservasi teknologi (technology preservation) yaitu perawatan secara seksama terhadap semua perangkat keras dan lunak yang dipakai untuk membaca dan menjalankan sebuah materi digital.

b. Preservasi dengan cara penyegaran atau pembaruan (refreshing) dengan memperhatikan usia media (memindahkan data dari media yang satu ke media yang lain)..

c. Preservasi dengan cara melakukan migrasi dan format ulang (migration and reformating) merupakan kegiatan mengubah konfigurasi data digital tanpa mengubah kandungan isi intelektualnya.

d. Preservasi dengan cara emulasi (emulation) yaitu proses "penyegaran" di lingkungan sistem, Artinya secara teoritis dapat dilakukan pembuatan ulang secara berkala terhadap program komputer tertentu agar dapat terus membaca data digital yang terekam dalam berbagai format dari berbagai versi.

e. Arkeologi, yaitu menyelamatkan isi dokumen yang tersimpan dalam media penyimpanan ataupun perangkat keras dan perangkat lunak yang sudah rusak, sehingga isi dokumen tersebut tetap dapat 
digunakan

f. Preservasi dengan cara mengubah data digital menjadi analog, terutama untuk materi digital yang sulit diselamatkan dengan semua cara di atas.

11. Memilih Teknik Preservasi Digital Yang Sesuai

Usaha penyelamatkan nilai informasi agar informasi dapat dimanfaatkan dalam waktu yang relatif lebih lama lagi dan terhindar dari kerusakan terhadap koleksi digital atau elektronik. Refressing, migrasi, dan emulasi adalah beberapa cara preservasi digital yang bisa menjadi pilihan bagi perpustakaan untuk melestarikan materi digital. Namun demikian, masing-masing metode tersebut mempunyai kelebihan dan kekurangan yang dapat dijadikan pertimbangan masing-masing perpustakaan.

a. Refreshing

Dibandingkan dengan media penyimpanan manual seperti kertas cetak yang memiliki masa ketahanan relatif panjang, media penyimpanan digital tidak memiliki nilai ketahanan yang lebih lama. Maka perawatan terhadap koleksi digital dapat dilakukan dengan cara refresing yaitu pemindahan data secara berkala. Pemindahan tersebut misalnya ari CD-ROM ke dalam hard-disk, atau data dalam disket dipindah ke dalam CD-ROM. Strategi refreshing adalah pemindahan koleksi digital dari satu medium ke medium lain yang sejenis ataupun medium yang lebih baru untuk mencegah keusangan teknologi, Susan (2001:76).

Tahapan-tahapan yang dapat dilakukan dalam strategi refreshing ini ada dua yaitu pemilihan media baru sebagai pengganti media yang lama dan pelaksanaan transfer data dari media lama ke media yang baru tersebut. Pada tahap pemilihan media baru, media penyimpanan yang lama perlu untuk dievaluasi terlebih dahulu agar diketahui kelebihan dan kekurangan dari media lama. Dengan dilakukannya evaluasi terhadap media lama tersebut dimaksudkan agar tidak terjadi kesalahan pemilihan media baru sehingga ketika ditentukan media baru sebagai media 
pengganti, pemilihan tersebut benar-benar efektif dan tidak salah langkah atau salah pilih. Langkah selanjutnya adalah tahap transfer data, yang mana data dipindahkan dari media penyimpanan yang digunakan sebelumnya ke media penyimpanan yang baru.

Tujuan utama dari refresing ini adalah untuk menciptakan koleksi digital yang sifatnya stabil. Kelebihan dari strategi ini adalah mudah diterapkan dan resiko kehilangan data dalam proses pemindahan data sangat kecil, Daryono (2011)

b. Migrasi

Migrasi adalah proses penyalinan data digital secara periodik dari media lama ke dalam media yang lebih baru, dengan format yang standard. Migrasi merupakan proses transfer koleksi digital dari konfigurasi perangkat keras dan perangkat lunak tertentu ke dalam konfigurasi lainnya, atau dari satu generasi teknologi komputer ke dalam teknologi komputer yang lebih baru, Susan (2001:77).

Chowdhury dan Sudatta Chowdhury dalam Introduction to Digital Libraries, menjelasjan secara lebih lengkap: "Migration is periodic transfer of digital materials from one hardware/ software configuration to another or from one generation of computer to a subsequent generation so as to preserve the integrity of digital objects and to retain the ability of user to retrieve, display and otherwise use them in the face of constantly changing technology.

Definisi tersebut menyatakan bahwa migrasi merupakan proses transfer koleksi digital secara periodik dari konfigurasi perangkat keras dan perangkat lunak tertentu ke dalam konfigurasi lainnya, atau dari satu generasi teknologi komputer ke generasi yang lebih baru dengan tujuan untuk melestarikan objek digital agar para pengguna dapat menemukan kembali, menampilkan dan menggunakan objek digital tersebut seiring dengan perubahan teknologi yang terjadi. Migrasi memuat perubahan konfigurasi yang mendasari data, tanpa mengubah isi intelektualnya. Strategi migrasi ini dilakukan agar koleksi digital yang tersimpan dapat 
terus diakses oleh penggunanya.

Strategi migrasi mencakup transfer data antar media penyimpanan eksternal (contohnya dari disket ke CD atau DVD), media penyimpanan internal (contohnya dari hardisk ke hardisk yang dapat diakses secara online), produk perangkat lunak (melaksanakan up date terhadap perangkat lunak yang digunakan), serta fomat penyimpanan (mengikuti format standar yang berlaku). Stielow (2004:191).

Strategi migrasi memiliki beberapa kelebihan dan kelemahan. Beberapa kelebihan strategi migrasi tersebut antara lain pertama, perpustakaan tidak perlu meyimpan aplikasi originalnya. Kedua, memungkinkan manajemen dan perawatan secara aktif. Ketiga, format standar menawarkan akses yang stabil dan berkelanjutan. Keempat, dengan strategi migrasi isi intelektual dari koleksi digital ini dapat dilestarikan. Adapun kelemahan-kelemahan strategi ini adalah diperlukannya perawatan secara berkelanjutan seiring dengan perkembangan teknologi sehingga menghabiskan banyak biaya.

c. Mengalih bentukkan ke dalam media analog

Berbeda dengan koleksi dalam bentuk analog yang lebih berusia panjang dan memiliki daya tahan lama, koleksi digital mempuyai kelemahan berupa sifat rapuh dan tidak tahan lama. Untuk mempertahankan koleksi digital agar dapat diakses oleh pengguna, koleksi digital dapat dialihbentukkan ke dalam media analog. Media tersebut adalah microfilm.

Mikrofilm dipilih karena media ini mempunyai tingkat ketahanan yang tinggi terhadap kerusakan. Strategi mengalihbentuk ke media analog ini dilakukan dengan memanfaatkan COM (Computer Output to Microfilm), yaitu data koleksi digital akan dicetak ke dalam mikrofilm. Strategi ini hanya cocok diterapkan pada koleksi digital dalam format teks seperti buku, jurnal atau sketsa dan tidak cocok untuk diterapkan pada gambar baik berwarna maupun tidak, karena akan banyak informasi yang hilang ketika data-data tersebut bila dialihbentukkan. Selain 
dialihkan ke dalam bentuk mikrofilm, strategi ini dapat dilakukan dengan membuat printout atau mencetak kembali dokumen yang telah didigitalisasi.

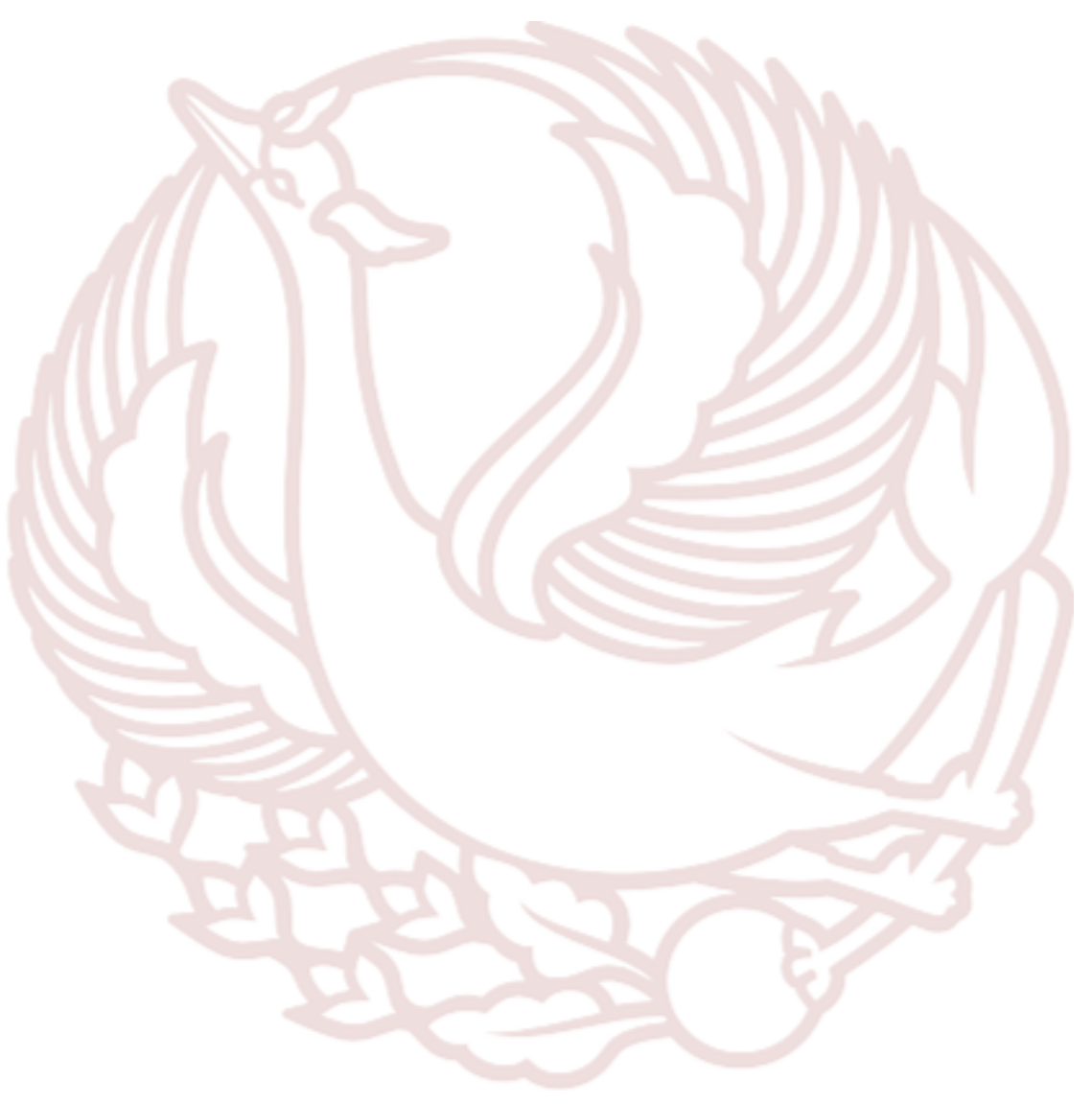




\section{BAB III \\ METODOLOGI PENELITIAN}

\section{A. Jenis Penelitian}

Penelitian ini merupakan penelitian lapangan (field Research) yang bersifat kualitatif serta menggunakan metode deskriptif. Penelitian kualitatif adalah suatu pendekatan penelitian yang diarahkan dalam memahami fenomena sosial dari perpektif partisipan, serta menggunakan strategi multi media, dengan menggunakan teknik pengumpulan data, dengan metode pertama interview, observasi dan studi dokumenter. Dalam pelaksanaan penelitian peneliti menyatu dengan situasi yang diteliti. Moleong (2005:6). Metode deskriptif, yaitu penelitian dilakukan dengan jalan mengumpulkan data, menyusun, mengklasifikasikan data, data yang terkumpul berupa kata-kata bukan angka, Moleong (2005:8).

Penelitian kualitatif berlangsung secara natural, data yang dikumpulkan dari orang-orang yang terlibat dalam tingkah laku alamiah, hasil penelitian kualitatif bersifat deskripsi analisis. Peneliti lebih mementingkan aspek keluasan data sehingga data atau hasil penelitian dianggap merupakan representasi dari seluruh populasi. Dalam hal ini, peneliti meneliti masalah Presevasi Koleksi Kaset Video Langka Ke Dalam Bentuk Digital Melalui Proses Alih Media (Studi Kasus di UPT Perpustakaan ISI Surakarta).

Selain menggunakan metode kualitatif, peneliti juga menggunakan metode partisipatori untuk melakukan preservasi digitalisasi, para pustakawan akan terlibat langsung dan turut dalam merencanakan proses preservasi yang didasarkan pada analisis sosial atau problem di lapangan. Penelitian ini termasuk penelitian tindakan yang bersifat kolaboratif untuk menanggulangi dinamika sosial, dalam hal ini adalah presevasi koleksi kaset video langka. 


\section{B. Lokasi dan Waktu Penelitian}

Penelitian yang dilakukan terkait dengan Presevasi Koleksi Kaset Video Langka Ke Dalam Bentuk Digital Melalui Proses Alih Media (Studi Kasus di UPT Perpustakaan ISI Surakarta) ini bertempat di Lantai 1 Gedung Perpustakaan Institut Seni Indonesia Surakarta, Jl. Ki Hajar Dewantara No. 19 Kentingan, Jebres Surakarta. Penelitian ini akan dilakukan mulai Bulan Mei 2018 hingga Bulan Oktober 2019.

\section{Teknik Pengumpulan Data}

Dalam keperluan analisis data, teknik pengumpulan data yang dilakukan peneliti adalah sebagai berikut:

1. Observasi

Observasi merupakan pengamatan meliputi kegiatan pemuatan perhatian terhadap suatu objek dengan menggunakan seluruh alat indra (Arikunto, 2010: 199). Penelitian ini memerlukan pencatatan secara sistematis terhadap fenomena-fenomena yang diselidiki oleh peneliti. Observasi juga digunakan untuk mengumpulkan data tentang kondisi lapangan baik pada saat pra-penelitian maupun saat penelitian berlangsung, sehingga diperoleh data/fakta yang akurat. Dalam observasi ini diterapkan suatu catatan lapangan (field notes). Dalam penelitian ini peneliti menggunakan observasi partisipan, yaitu observasi yang dilakukan oleh peneliti yang berperan sebagai anggota yang berperan serta dalam kehidupan masyarakat topik penelitian, Emzir (2014:39)

Menurut Emzir (2014:41-44) beberapa petunjuk pokok observasi yang baik yaitu :

a) Peroleh dari informasi yang sudah ada tentang sesuatu yang ingin diamati. Peneliti harus menetapkan sebelumnya aspek-aspek yang ingin diobservasinya, dan gejala-gejala yang patut dicatat atau direkam.

b) Menguji tujuan umum dan tujuan khusus

c) Berpegang pada teknik tertentu untuk mencatat hasil. 
d) Mengklasifikasi dan membatasi informasi

e) Mengamati dengan cermat dan teliti

f) Menyusun fenomena-fenomena tersebut secara terpisah

g) Berlatih menggunakan alat-alat yang dipergunakan dalam observasi.

\section{Studi Literatur}

Satu hal yang jugasangat penting ketika melakukan penelitian adalah melakukan kajian kepustakaan (literarure review) baik sebelum maupun selama penelitian dilangsungkan. Kegiatan kajian pustaka ini dapat dilakukan dengan memilih dan memilah sumber bacaan yang relevan dan sesuai dengan bidang ilmu serta kajian yang hendak dijadikan penelitian. Widi (2010:118).

Cara ini dilakukan peneliti melalui pencatatan data literatur, mencermati arsip dan dokumentasi terkait penelitian ini. Pemahaman terhadap data dokumenter akan melengkapi data yang dimiliki peneliti sehingga dapat menjelaskan permasalahan penelitian secara terperinci. Melihat hasil-hasil penelitian yang pernah dilakukan orang lain yang terkait dengan penelitian ini.

\section{Dokumentasi}

Metode ini digunakan untuk mengadakan penelitian yang bersumber pada buku, hasil penelitian, peraturan-peraturan, dokumen-dokumen dan sebagainya, Sugiono (2012:300). Dalam hal ini peneliti mencari dan melihat dokumen-dokumen yang berkaitan dengan Presevasi Koleksi Kaset Video Langka Ke Dalam Bentuk Digital Melalui Proses Alih Media (Studi Kasus di UPT Perpustakaan ISI Surakarta).

4. Wawancara

Dalam bentuknya yang paling sederhana wawancara terdiri atas sejumlah pertanyaan yang dipersiapkan oleh peneliti dan diajukan kepada seseorang mengenai topik penelitian secara tatap muka, dan peneliti merekam jawaban-jawabannya sendiri, Emzir (2014:49;50). Wawancara yang dilakukan peneliti mempunyai tujuan tertentu agar tidak menjadi suatu percakapan yang tidak sistematis atau melakukan pengamatan yang 
tidak mempunyai ujung pangkal. Oleh karena itu, peneliti yang melakukan wawancara mempunyai tiga kewajiban, yaitu :

a) memberitahu informan tentang hakikat penelitian dan pentingnya kerjasama mereka dengan peneliti.

b) Menghargai informan atas kerja samanya, dan

c) Memperoleh informasi dan data yang diinginkannya

Berdasarkan bentuk-bentuk pertanyaan yang diajukan, peneliti menggunakan wawancara secara terbuka, yaitu wawancara yang dilakukan peneliti dengan mengajukan pertanyaan-pertanyaan yang tidak dibatasi jawabannya, artinya pertanyaan yang mengundang jawaban terbuka, Emzir (2014:51). Menurut Emzir (2014:53-59) ada beberapa hal yang perlu dipertimbangkan dalam wawancara, yaitu :

a) Menentukan orang-orang yang akan diwawancarai

b) Membuat rencana yang jelas untuk wawancara yangberisi pertanyaan-pertanyaan yang akan diajukan

c) Menyiapkn catatan tertulis tentang hasil wawancara secepat mungkin

d) Meyakini kebenaran informasi yang diperoleh

\section{Tahapan Penelitian}

Tahapan penelitian yang dilakukan adalah:

1) Observasi koleksi di Perpustakaan Institut Seni Indonesia Surakarta

2) Menyusun daftar koleksi video langka di perpustakaan ISI Surakarta

3) Melakukan koordinasi dengan pustakawan pelaksana preservasi

4) Mempersiapkan peralatan preservasi

5) Melaksanakan proses preservasi

6) Olah data digitalisasi 


\section{BAB IV \\ PEMBAHASAN}

Sejarah UPT Perpustakaan ISI Surakarta berawal pada tanggal 13 Januari 1971 yang dibidangi oleh Bapak Soekanto yang ditunjuk oleh Pimpinan Akademi Seni Karawitan (ASKI) Surakarta untuk mwngikuti kursus perpustakaan yang diselenggarakan oleh IKIP Negeri Surakarta. Setelah itu lahirlah sebuah perpustakaan sederhana yang berluas $2 \times 2 \mathrm{~m}^{2}$ yang berada di Konservatori Karawitan Indonesia Kepatihan Surakarta.

Pada tahun 1972 perpustakaan menempati ruangan di Sitihinggil dengan luas ruangan $4 \times 3 \mathrm{~m}^{2}$.Pada saat itu ASKI Surakarta menjalankan aktivitasnya di Pagelaran Sitihinggil dan Sasonomulyo Keraton Kasunanan Surakarta Hadiningrat atas fasilitas dari Proyek Pengembangan Kesenian Jawa Tengah di Surakarta.

Dalam pelaksanaanya Institut Seni Indonesia Surakarta memiliki visi dan misi. Visi dan misi tersebut adalah: Visi ISI Surakarta adalah menjadi perguruan tinggi seni berbasis kearifan budaya nusantara yang berkelas dunia dalam sistem tata kelola yang akuntabel dan transparan. Misi ISI Surakarta adalah melaksanakan pendidikan, penelitian, dan pengabdian kepada masyarakat dalam rangka pelestarian dan pengembangan seni dan ilmu seni berbasis budaya nusantara yang unggul dan bermanfaat bagi masyarakat.

Perpustakaan adalah gudang informasi, kualitas perpustakaan dapat ditentukan dari koleksi yang dimilikinya. Untuk memenuhi kebutuhan tersebut Perpustakaan ISI Surakarta memiliki berbagai macam koleksi antara lain: teks-book, buku non cetak, jurnal, majalah, buletin, surat kabar, katalog penerbit, kamus, ensiklopedi, peraturan pemerintah, peta, atlas, pustaka rekreatif, kliping, pustaka pandang dengar, dan koleksi digital.

Selain koleksi karya ilmiah seperti skripsi, thesis, dan disertasi, Perpustakaan ISI Surakarta juga memiliki koleksi yang berlangganan seperti surat kabar. Perpustakaan ISI melanggan surat kabar Solopos dan Kompas. Selain 
surat kabar Perpustakaan ISI memiliki koleksi dalam bentuk yang lain yitu kliping dan data hasil penelusuran. ISI Surakarta adalah institut seni yang memiliki program studi pedalangan, tari, dan karawitan.Program studi tersebut sangat membutuhkan koleksi yang berbentuk audio dan visual. Perpustakaan ISI Surakarta juga memiliki koleksi di Institutuional Repository.Institutional Repository ISI Surakarta dapat diakses melalui http://repository.isi-ska.ac.id. Institutional Repository dibangun untuk menjadi salah satu media penyimpanan hasil karya dan penelitian civitas akademika ISI Surakarta.

Perpustakaan ISI Surakarta merupakan perpustakaan Perguruan Tinggi di bawah naungan Kemristekdikti. Selain memiliki koleksi bahan pustaka buku, perpustakaan ini juga memiliki koleksi pustaka non buku, khususnya adalah koleksi audio visual. Pada pembahasan ini akan diulas secara detail proses Preservasi Koleksi Kaset Video Langka Ke Dalam Bentuk Digital Melalui Proses Alih Media di UPT Perpustakaan ISI Surakarta.

Tahapan penelitian yang dilakukan adalah:

\section{Observasi koleksi di Perpustakaan Institut Seni Indonesia Surakarta}

Perpustakaan adalah gudang informasi, kualitas perpustakaan dapat ditentukan dari koleksi yang dimilikinya. Untuk memenuhi kebutuhan tersebut Perpustakaan ISI Surakarta memiliki berbagai macam koleksi antara lain: teks-book, buku non cetak, jurnal, majalah, buletin, surat kabar, katalog penerbit, kamus, ensiklopedi, peraturan pemerintah, peta, atlas, pustaka rekreatif, kliping, pustaka pandang dengar, dan koleksi digital. Data koleksi Perpustakaan Institut Seni Surakarta dapat dilihat dari tabel berikut: 
Tabel 4. Data Jumlah Koleksi Buku Perpustakaan ISI Surakarta

\begin{tabular}{|l|l|l|l|l|l|l|l|l|l|}
\hline No & Asal Koleksi & \multicolumn{2}{|c|}{$\begin{array}{c}\text { Tambahan } \\
\text { 2017 }\end{array}$} & \multicolumn{2}{|c|}{ 2017 } & \multicolumn{2}{c|}{ Tambahan } & \multicolumn{2}{|c|}{2018} \\
\cline { 3 - 10 } & & Judul & Eks & Judul & Eks & Judul & Eks & Judul & Eks \\
\hline & Buku : & & & & & & & & \\
\hline 1. & Pembelian & 244 & 546 & & & 270 & 594 & & \\
\hline 2. & Hibah & & & & & & & & \\
\hline 3. & $\begin{array}{l}\text { Sumbangan } \\
\text { Lembaga } \\
\text { Lain }\end{array}$ & 53 & 200 & & & 28 & 40 & & \\
\hline 4. & $\begin{array}{l}\text { Sumbangan } \\
\text { Pribadi }\end{array}$ & 59 & 109 & & & 45 & 86 & & \\
\hline 5. & $\begin{array}{l}\text { Sumbangan } \\
\text { Dosen }\end{array}$ & & & & & & & & \\
\hline 6. & $\begin{array}{l}\text { Sumbangan } \\
\text { Mahasiswa }\end{array}$ & & & & 1 & & & & \\
\hline & Jumlah & 356 & 856 & 24694 & 48984 & 343 & 720 & 25037 & 49704 \\
\hline
\end{tabular}

Sumber : Data UPT Perpustakaan ISI Surakarta

Keterangan

Eks $=$ Eksemplar

Tabel 5. Data Koleksi Majalah dan Jurnal

\begin{tabular}{|c|c|c|c|c|c|c|c|c|c|}
\hline \multirow[t]{2}{*}{ No } & \multirow[t]{2}{*}{$\begin{array}{c}\text { Asal } \\
\text { Koleksi }\end{array}$} & \multicolumn{2}{|c|}{$\begin{array}{c}\text { Tambahan } \\
2017\end{array}$} & \multicolumn{2}{|c|}{2017} & \multicolumn{2}{|c|}{$\begin{array}{c}\text { Tambahan } \\
2018\end{array}$} & \multicolumn{2}{|c|}{2018} \\
\hline & & Judul & Eks & Judul & Eks & Judul & Eks & Judul & Eks \\
\hline & $\begin{array}{l}\text { Majalah dan } \\
\text { Jurnal }\end{array}$ & & 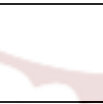 & & & & & & \\
\hline \multirow[t]{3}{*}{1} & Sumbangan & 2 & 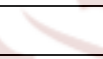 & & & 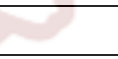 & & & \\
\hline & $\begin{array}{l}\text {-Dalam } \\
\text { Negeri }\end{array}$ & 16 & 73 & & & 10 & 68 & & \\
\hline & $\begin{array}{l}\text {-Luar } \\
\text { Negeri }\end{array}$ & & $\infty$ & & & & & & \\
\hline \multirow[t]{3}{*}{2} & Pembelian & & & & & & & & \\
\hline & $\begin{array}{l}\text {-Dalam } \\
\text { Negeri }\end{array}$ & 2 & 199 & & & 11 & 102 & & \\
\hline & $\begin{array}{l}\text {-Luar } \\
\text { Negeri }\end{array}$ & & & & & & & & \\
\hline \multirow[t]{3}{*}{3} & Hibah & & & & & & & & \\
\hline & $\begin{array}{l}\text { Hibah } \\
\text { Luar/Dalam } \\
\text { Negeri }\end{array}$ & & & & & & & & \\
\hline & Jumlah & 18 & 272 & 871 & 11673 & 21 & 170 & 892 & 11843 \\
\hline
\end{tabular}

Sumber : Data UPT Perpustakaan ISI Surakarta 
Tabel 6. Rekapitulasi Jumlah Majalah dan Jurnal

\begin{tabular}{|c|l|c|c|}
\hline No. & & Tahun 2017 & Tahun 2018 \\
\hline 1 & Judul & 871 & 892 \\
\hline 2 & Eksemplar & 11673 & 11843 \\
\hline
\end{tabular}

Sumber : Data UPT Perpustakaan ISI Surakarta

Tabel 7. Data Jumlah Buku Karya Ilmiah

\begin{tabular}{|c|c|c|c|c|c|c|c|c|}
\hline \multirow[t]{2}{*}{ No } & \multirow{2}{*}{$\begin{array}{c}\text { Asal } \\
\text { Sumber }\end{array}$} & \multirow{2}{*}{ Jenis } & \multicolumn{2}{|c|}{2016} & \multicolumn{2}{|c|}{2017} & \multicolumn{2}{|c|}{2018} \\
\hline & & & Jud & Eks & Jud & Eks & Jud & Eks \\
\hline \multirow[t]{7}{*}{1} & \multirow[t]{7}{*}{ Karawitan } & $\begin{array}{l}\text { Penyajian } \\
\text { Karawitan }\end{array}$ & 535 & 791 & 578 & 836 & 604 & 862 \\
\hline & & $\begin{array}{l}\text { Skripsi } \\
\text { Etnomusikologi }\end{array}$ & 168 & 168 & 194 & 194 & 233 & 233 \\
\hline & & $\begin{array}{l}\text { Skripsi } \\
\text { Karawitan }\end{array}$ & 153 & 167 & 167 & 181 & 180 & 194 \\
\hline & & Pembawaan & 46 & 112 & 46 & 112 & 46 & 112 \\
\hline & & $\begin{array}{l}\text { Deskrips Tesis } \\
\text { Musik }\end{array}$ & 9 & & 17 & 17 & 17 & 17 \\
\hline & & Tesis Musik & & 9 & 17 & 17 & 17 & 17 \\
\hline & & $\begin{array}{l}\text { Deskripsi } \\
\text { Etnomusikologi }\end{array}$ & 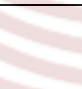 & & 1 & 1 & 1 & 1 \\
\hline \multirow[t]{6}{*}{2} & \multirow[t]{6}{*}{ Pedalangan } & $\begin{array}{l}\text { Penyajian } \\
\text { Pedalangan }\end{array}$ & 165 & 233 & 173 & 241 & 183 & 251 \\
\hline & & $\begin{array}{l}\text { Skripsi } \\
\text { Pedalangan }\end{array}$ & 93 & 93 & 99 & 99 & 110 & 110 \\
\hline & & $\begin{array}{l}\text { Pembawaan } \\
\text { Pedalangan }\end{array}$ & 3 & 8 & 3 & 8 & 3 & 8 \\
\hline & & Skripsi Teater & 4 & 4 & 14 & 14 & 14 & 14 \\
\hline & & Deskripsi Teater & 1 & 1 & 12 & 12 & 12 & 12 \\
\hline & & Tesis Teater & 4 & 4 & 7 & 7 & 7 & 7 \\
\hline \multirow[t]{8}{*}{3} & \multirow[t]{8}{*}{ Seni Rupa } & $\begin{array}{l}\text { Deskripsi } \\
\text { Desain Interior }\end{array}$ & 69 & 69 & 91 & 91 & 109 & 109 \\
\hline & & $\begin{array}{l}\text { Deskripsi Kriya } \\
\text { Seni }\end{array}$ & 96 & 96 & 109 & 109 & 122 & 122 \\
\hline & & $\begin{array}{l}\text { Deskripsi Seni } \\
\text { Murni }\end{array}$ & 27 & 27 & 31 & 31 & 38 & 38 \\
\hline & & $\begin{array}{l}\text { Deskripsi } \\
\text { Teknik Kriya }\end{array}$ & 172 & 172 & 172 & 172 & 172 & 172 \\
\hline & & $\begin{array}{l}\text { Deskripsi Tata } \\
\text { Rupa Panggung }\end{array}$ & 158 & 158 & 158 & 158 & 158 & 158 \\
\hline & & $\begin{array}{l}\text { Deskripsi TV } \\
\text { dan Film }\end{array}$ & 79 & 79 & 86 & 86 & 107 & 107 \\
\hline & & Deskripsi DKV & & & & & 17 & 17 \\
\hline & & $\begin{array}{l}\text { Deskripsi } \\
\text { Fotografi }\end{array}$ & & & & & 8 & 8 \\
\hline
\end{tabular}




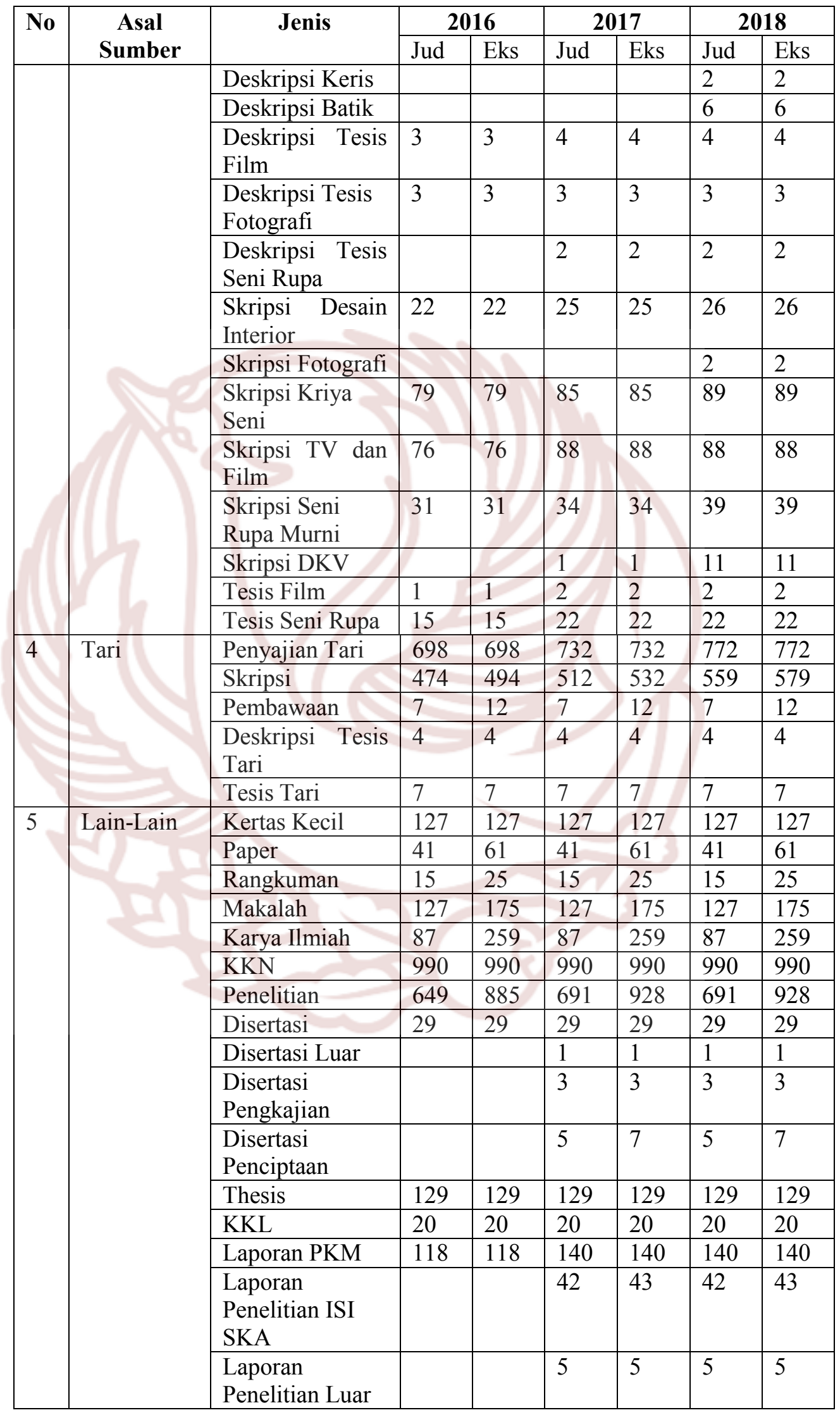




\begin{tabular}{|c|c|c|c|c|c|c|c|c|}
\hline \multirow[t]{2}{*}{ No } & \multirow{2}{*}{$\begin{array}{c}\text { Asal } \\
\text { Sumber }\end{array}$} & \multirow[t]{2}{*}{ Jenis } & \multicolumn{2}{|c|}{2016} & \multicolumn{2}{|c|}{2017} & \multicolumn{2}{|c|}{2018} \\
\hline & & & Jud & Eks & Jud & Eks & Jud & Eks \\
\hline & & $\begin{array}{l}\text { Lap. Penciptaan } \\
\text { Seni }\end{array}$ & 16 & 16 & 16 & 16 & 16 & 16 \\
\hline & & $\begin{array}{l}\text { Thesis Luar } \\
\text { Akademik }\end{array}$ & 1 & 1 & 2 & 2 & 2 & 2 \\
\hline & & $\begin{array}{l}\text { Skripsi Luar } \\
\text { Akademik }\end{array}$ & 14 & 14 & 15 & 15 & 15 & 15 \\
\hline \multicolumn{3}{|c|}{ Jumlah } & 5574 & 6494 & 5988 & 6914 & 6288 & 7214 \\
\hline
\end{tabular}

Sumber : Data UPT Perpustakaan ISI Surakarta

Keterangan : Jud $=$ Judul $\quad$ Eks $=$ Eksemplar

Selain koleksi karya ilmiah seperti skripsi, thesis, dan disertasi, Perpustakaan ISI Surakarta juga memiliki koleksi yang berlangganan seperti surat kabar. Perpustakaan ISI melanggan surat kabar Solopos dan Kompas. Selain surat kabar Perpustakaan ISI memiliki koleksi dalam bentuk yang lain yitu kliping dan data hasil penelusuran. ISI Surakarta adalah institut seni yang memiliki program studi pedalangan, tari, dan karawitan. Program studi tersebut sangat membutuhkan koleksi yang berbentuk audio dan visual. Selengkapnya jumlah masing-masing koleksi di atas dapat dilihat dalam tabel sebagai berikut:

Tabel 8. Data Jumlah Koleksi Surat Kabar

\begin{tabular}{|c|l|c|c|c|}
\hline No. & \multicolumn{1}{|c|}{ Nama Surat Kabar } & Eks 2016 & Eks 2017 & Eks 2018 \\
\hline 1. & Kompas & 350 & 350 & 350 \\
\hline 2. & Solopos & 350 & 350 & 350 \\
\hline & Jumlah & $\mathbf{7 0 0}$ & $\mathbf{7 0 0}$ & $\mathbf{7 0 0}$ \\
\hline
\end{tabular}

Sumber : Data UPT Perpustakaan ISI Surakarta 
Tabel 9. Data Konten Institutional Repository ISI Surakarta

\begin{tabular}{|c|c|c|c|}
\hline No & Jenis Koleksi & $\begin{array}{c}\text { Tahun } \\
2017\end{array}$ & Tahun 2018 \\
\hline 1 & Book & 11 & 22 \\
\hline 2 & Book section & 1 & 2 \\
\hline 3 & Monograph & 4 & 129 \\
\hline 4 & $\begin{array}{l}\text { Thesis (Skripsi, Deskripsi, Thesis, } \\
\text { Disertasi) }\end{array}$ & 4 & 129 \\
\hline 5 & $\begin{array}{l}\text { Conference or Workshop Item } \\
\text { (Makalah) }\end{array}$ & 18 & 22 \\
\hline 6 & $\begin{array}{l}\text { Article (Jurnal, Koran, Majalah, } \\
\text { dsb) }\end{array}$ & 545 & 710 \\
\hline 7 & Audio & 653 & 703 \\
\hline 8 & Video & 54 & 209 \\
\hline 9 & Show/Exhibition (Katalog) & 1 & 2 \\
\hline 10 & Artefact & 1 & 1 \\
\hline 11 & Patent (HAKI) & 11 & 11 \\
\hline 12 & $\begin{array}{l}\text { Other / Lain-Lain (Laporan } \\
\text { Penelitian, Panduan, dsb) }\end{array}$ & 61 & 62 \\
\hline . & Jumlah & 1883 & 2727 \\
\hline
\end{tabular}

Sumber : Data UPT Perpustakaan ISI Surakarta 
Tabel 10. Data koleksi pandang dengar

\begin{tabular}{|c|l|l|l|l|l|l|l|}
\hline No. & $\begin{array}{c}\text { Nama } \\
\text { Barang }\end{array}$ & $\mathbf{2 0 1 4}$ & $\mathbf{2 0 1 5}$ & $\mathbf{2 0 1 6}$ & $\mathbf{2 0 1 7}$ & $\mathbf{2 0 1 8}$ & Satuan \\
\hline 1. & Kaset audio & 9608 & 9608 & 9608 & 9608 & 9608 & Keping \\
\hline 2. & Kaset video & 936 & 936 & 936 & 936 & 936 & Keping \\
\hline 3. & $\begin{array}{l}\text { Piringan } \\
\text { hitam }\end{array}$ & 370 & 370 & 370 & 370 & 370 & Keping \\
\hline 4. & Pita reel & 109 & 109 & 109 & 109 & 109 & Keping \\
\hline 5. & CD & 646 & 646 & 646 & 646 & 646 & Keping \\
\hline 6. & VCD & 1320 & 1320 & 1320 & 1332 & 1332 & Keping \\
\hline 7. & DVD & 60 & 60 & 60 & 60 & 60 & Keping \\
\hline & Jumlah & $\mathbf{1 3 0 4 9}$ & $\mathbf{1 3 0 4 9}$ & $\mathbf{1 3 0 4 9}$ & $\mathbf{1 3 0 6 1}$ & $\mathbf{1 3 0 6 1}$ & Keping \\
\hline
\end{tabular}

Sumber : Data UPT Perpustakaan ISI Surakarta

Tabel 11. Jumlah Koleksi Kaset Video

\begin{tabular}{|c|l|c|c|}
\hline No. & \multicolumn{1}{|c|}{ Jenis Koleksi } & Jumlah Koleksi & Satuan \\
\hline 1 & Kaset Audio & 8.045 & Eksemplar \\
\hline 2 & Piringan Audio & 370 & Eksemplar \\
\hline 3 & Kacet CD & 40 & Eksemplar \\
\hline 4 & Kaset Video & 896 & Eksemplar \\
\hline 5 & Kaset VCD & 568 & Eksemplar \\
\hline & Jumlah : & $\mathbf{9 . 9 1 9}$ & Eksemplar \\
\hline
\end{tabular}

Sumber : Koleksi UPT Perpustakaan ISI Surakarta, 2018. 


\section{Menyusun daftar koleksi video langka di perpustakaan ISI Surakarta}

Dalam menentukan dan mendaftar koleksi video yang termasuk langka, pertama peneliti mendalami pengertian video yang berpedoman pada Kamus Besar Bahasa Indonesia (2017:1843). Menurut KBBI video adalah 1) bagian yang memancarkan gambar pada pesawat televise; 2) rekaman gambar hidup atau program televise untuk ditayangkan lewat pesawat televise. Yang Kedua mengacu pada pendapat Dagung dalam Ervina (2018:19), yang menyatakan bahwa video merupakan tek pesawat yang memancarkan gambar pada pesawat televisi, alat merekam gambar hidup dan bisa ditayangkan kembali lewat layar televise.

Pengertian koleksi langka, peneliti berpdedoman dari beberpa pengertian yang sudah ada, yaitu 1) Menurut beberapa pakar di Indonesia Koleksi langka adalah buku yang sudah sangat sulit didapatkan di pasaran, walau buku tersebut dicetak masih baru, karena terbatasnya eksemplar (http://digilib.pnri.go.id) 2) Menurut Susanto Zuhdi koleksi langka adalah koleksi yang sudah tidak terbit lagi, sekalipun usianya belum begitu lama. (http://www. perpusnas.go.id) 3) Sedangkan menurut Badan Perpustakaan dan arsip Daeah Propinsi DIY sendiri mendefinisikan koleksi langka, pustaka langka atau disebut juga antique books adalah suatu jenis koleksi yang memiliki ciri-ciri yang tidak diterbitkan lagi, sudah tidak beredar di pasaran, susah untuk mendapatkannya, mempunyai kandungan informasi yang tetap, memiliki informasi kesejarahan. (http://www.badanperpusda-diy.go.id). Jadi koleksi langka adalah koleksi yang sulit ditemukan dipasaran karena sudah tidak diterbitkan lagi. Koleksi buku yang masih baru dapat dikatakan koleksi langka karena jumlah eksemplar yang terbatas.

Kemudian dari keterangan di atas peneliti menyimpulkan bahwa kaset video langka yaitu rekaman gambar hidup atau program televise untuk ditayangkan lewat pesawat televise atau tek pesawat yang memancarkan gambar pada pesawat televise atau visual yang menampilkan gerak yang sudah sangat sulit didapatkan di pasaran, tidak diterbitkan dan sudah susah ditemukan alat pemutarnya. 
Adapun kaset video langka yang dipilih peneliti untuk dipreservasi adalah sebagai berikut :

\begin{tabular}{|c|c|c|c|c|c|}
\hline NO & $\begin{array}{l}\text { JUDUL } \\
\text { KASET }\end{array}$ & TEMPAT & TAHUN & PENYAJI & KET \\
\hline 1 & $\begin{array}{l}\text { Tari Topeng } \\
\text { Dermayon }\end{array}$ & $\begin{array}{l}\text { STSI } \\
\text { Surakarta }\end{array}$ & $\begin{array}{l}21 \\
\text { Februari } \\
1999\end{array}$ & $\begin{array}{l}\text { Grup Mulya } \\
\text { Bakti }\end{array}$ & \\
\hline 2 & $\begin{array}{l}\text { Wayang } \\
\text { Jemblung } \\
\text { "Kamandaka" }\end{array}$ & $\begin{array}{l}\text { STSI } \\
\text { Surakarta }\end{array}$ & $\begin{array}{l}23 \\
\text { Februari } \\
1999\end{array}$ & $\begin{array}{l}\text { Ki Suparman } \\
\text { Hadi Prayitno }\end{array}$ & \\
\hline 3 & $\begin{array}{l}\text { Dokumentasi } \\
\text { Paket Tari } \\
\text { Wayang Sunda } \\
\text { (Tari Antareja, } \\
\text { Tari Arjuna } \\
\text { Sumantri, Tari } \\
\text { Baladewa, Tari } \\
\text { Jayengrana) }\end{array}$ & $\begin{array}{l}\text { ASTI } \\
\text { Bandung }\end{array}$ & $\begin{array}{l}5 \text { Februari } \\
1992\end{array}$ & $\begin{array}{l}\text { Een Herdiani } \\
\text { Lilis Sumiati } \\
\text { dan Taufik } \\
\text { Hidayat } \\
\text { Een Herdiani } \\
\text { Lilis Sumiati }\end{array}$ & \\
\hline 4 & $\begin{array}{l}\text { Dokumentasi } \\
\text { Paket Tari } \\
\text { Wayang Sunda } \\
\text { (Tari Badaya, } \\
\text { Tari } \\
\text { Gandamanah, } \\
\text { Tari Gathutkaca } \\
\text { Sakipu, Tari } \\
\text { Gathutkaca) }\end{array}$ & $\begin{array}{l}\text { ASTI } \\
\text { Bandung }\end{array}$ & $\begin{array}{l}5 \text { Februari } \\
1992\end{array}$ & $\begin{array}{l}\text { Lilis Sumiati, } \\
\text { Diah, Setiawati, } \\
\text { Felly } \\
\text { Een Herdiani } \\
\text { Een Herdiani } \\
\text { dan Ahmat } \\
\text { Farmis } \\
\text { Een Herdiani }\end{array}$ & \\
\hline 5 & $\begin{array}{l}\text { Dokumentasi } \\
\text { Paket Tari } \\
\text { Wayang Sunda } \\
\text { (Tari Srikandi } \\
\text { Mustokoweni, } \\
\text { Tari Subadra, } \\
\text { Tari Sunda I, } \\
\text { Tari Sunda II) }\end{array}$ & $\begin{array}{l}\text { ASTI } \\
\text { Bandung }\end{array}$ & $\begin{array}{l}5 \text { Februari } \\
1992\end{array}$ & $\begin{array}{l}\text { Lilis Sumiati, } \\
\text { Diah Dahliati } \\
\text { Lilis Sumiati }\end{array}$ & \\
\hline 6 & $\begin{array}{l}\text { Materi Kuliah } \\
\text { Tari Gaya } \\
\text { Surakarta } \\
\text { Tari Bedhaya } \\
\text { Pangkur } \\
\text { Tari Srimpi } \\
\text { Dempel Pendek }\end{array}$ & $\begin{array}{l}\text { STSI } \\
\text { Surakarta }\end{array}$ & & STSI Surakarta & \\
\hline
\end{tabular}




\begin{tabular}{|c|c|c|c|c|}
\hline 7 & $\begin{array}{l}\text { Materi Kuliah } \\
\text { Tari Gaya } \\
\text { Surakarta: Tari } \\
\text { Bedhaya } \\
\text { Duradasih, Tari } \\
\text { Bedhaya Lala }\end{array}$ & $\begin{array}{l}\text { STSI } \\
\text { Surakarta }\end{array}$ & & STSI Surakarta \\
\hline 8 & $\begin{array}{l}\text { Materi Kuliah } \\
\text { Tari Gaya } \\
\text { Surakarta: Tari } \\
\text { Klono Topeng, } \\
\text { Tari Srikandi } \\
\text { Mustokoweni, } \\
\text { Tari Karonsih }\end{array}$ & $\begin{array}{l}\text { STSI } \\
\text { Surakarta }\end{array}$ & & $\begin{array}{l}\text { S. Maridi } \\
\text { STSI Surakarta }\end{array}$ \\
\hline 9 & $\begin{array}{l}\text { Materi Kuliah } \\
\text { Tari Gaya } \\
\text { Surakarta: Tari } \\
\text { Srimpi Dempel } \\
\text { Panjang }\end{array}$ & $\begin{array}{l}\text { STSI } \\
\text { Surakarta }\end{array}$ & & STSI Surakarta \\
\hline 10 & $\begin{array}{l}\text { Asean } \\
\text { Composer } \\
\text { Music } \\
\text { Workshop: } \\
\text { Komposisi Dari } \\
\text { Indonesia, } \\
\text { Mudik Lebaran, } \\
\text { Main Kayu, } \\
\text { Urat Kawat, } \\
\text { Balung Wesi }\end{array}$ & $\begin{array}{l}\text { Pendopo } \\
\text { STSI } \\
\text { Surakarta }\end{array}$ & $\begin{array}{l}20 \text { Maret } \\
1995\end{array}$ & $\begin{array}{l}\text { Darsono, S.Kar } \\
\text { Dr. R. } \\
\text { Supanggah, } \\
\text { S.Kar, I Wayan } \\
\text { Sadra, S. Kar }\end{array}$ \\
\hline 11 & $\begin{array}{l}\text { Dokumentasi } \\
\text { Pentas Karya } \\
\text { Dosen Dan } \\
\text { Asisten : Tari } \\
\text { Anoman } \\
\text { Indrajit, Kiblat } \\
\text { Papat Lima } \\
\text { Pancer }\end{array}$ & $\begin{array}{l}\text { Pendopo } \\
\text { STSI } \\
\text { Surakarta }\end{array}$ & $\begin{array}{l}27 \text { Januari } \\
1993\end{array}$ & $\begin{array}{l}\text { Jonet Sri } \\
\text { Kuncoro } \\
\text { Wahyu Santosa } \\
\text { Prabowo }\end{array}$ \\
\hline 12 & $\begin{array}{l}\text { Dokumentasi } \\
\text { Pentas Karya } \\
\text { Dosen Dan } \\
\text { Asisten: Tari } \\
\text { Arya ( Bali ), } \\
\text { Tari Dadap }\end{array}$ & $\begin{array}{l}\text { Pendopo } \\
\text { STSI } \\
\text { Surakarta }\end{array}$ & $\begin{array}{l}27 \text { Januari } \\
1993\end{array}$ & $\begin{array}{l}\text { Komang Yuli } \\
\text { dan Nyoman } \\
\text { Wati, } \\
\text { Didik, } \\
\text { Bambang } \\
\text { Wahyudi }\end{array}$ \\
\hline
\end{tabular}




\begin{tabular}{|c|c|c|c|c|}
\hline 13 & $\begin{array}{l}\text { Festifal Topeng } \\
\text { Tradisional } \\
\text { Oleh } \\
\text { Masyarakat } \\
\text { Musikologi } \\
\text { Indonesia: } \\
\text { Topeng Hudog }\end{array}$ & $\begin{array}{l}\text { ASTI } \\
\text { Bandung }\end{array}$ & $\begin{array}{l}2 \\
\text { Nopember } \\
1990\end{array}$ & $\begin{array}{l}\text { Team Kesenian } \\
\text { Kalimantan } \\
\text { Timur }\end{array}$ \\
\hline 14 & $\begin{array}{l}\text { Festifal Topeng } \\
\text { Tradisional } \\
\text { Oleh } \\
\text { Masyarakat } \\
\text { Musikologi } \\
\text { Indonesia: } \\
\text { Topeng } \\
\text { Babakan }\end{array}$ & $\begin{array}{l}\text { ASTI } \\
\text { Bandung }\end{array}$ & $\begin{array}{l}2 \\
\text { Nopember } \\
1990\end{array}$ & $\begin{array}{l}\text { Team Kesenian } \\
\text { Cirebon Jawa } \\
\text { Barat }\end{array}$ \\
\hline 15 & $\begin{array}{l}\text { Festival Topeng } \\
\text { Tradisional } \\
\text { Oleh } \\
\text { Masyarakat } \\
\text { Musikologi } \\
\text { Indonesia: } \\
\text { Topeng } \\
\text { Huda-Huda }\end{array}$ & $\begin{array}{l}\text { ASTI } \\
\text { Bandung }\end{array}$ & $\begin{array}{l}2 \\
\text { Nopember } \\
1990\end{array}$ & $\begin{array}{l}\text { Team Kesenian } \\
\text { Simalungun } \\
\text { Sumatera Utara }\end{array}$ \\
\hline 16 & $\begin{array}{l}\text { Festival Topeng } \\
\text { Tradisional } \\
\text { Oleh } \\
\text { Masyarakat } \\
\text { Musikologi } \\
\text { Indonesia: } \\
\text { Topeng Irian } \\
\text { Jaya }\end{array}$ & $\begin{array}{l}\text { ASTI } \\
\text { Bandung }\end{array}$ & $\begin{array}{l}2 \\
\text { Nopember } \\
1990\end{array}$ & $\begin{array}{l}\text { Team Kesenian } \\
\text { Irian Jaya }\end{array}$ \\
\hline 17 & $\begin{array}{l}\text { Festifal Topeng } \\
\text { Tradisional } \\
\text { Oleh } \\
\text { Masyarakat } \\
\text { Musikologi } \\
\text { Indonesia } \\
\text { Topeng Dalang } \\
\text { Madura }\end{array}$ & $\begin{array}{l}\text { ASTI } \\
\text { Bandung }\end{array}$ & $\begin{array}{l}2 \\
\text { Nopember } \\
1990\end{array}$ & $\begin{array}{l}\text { Team Kesenian } \\
\text { Madura }\end{array}$ \\
\hline 18 & $\begin{array}{l}\text { Festifal Topeng } \\
\text { Tradisional } \\
\text { Oleh } \\
\text { Masyarakat } \\
\text { Musikologi } \\
\text { Indonesia } \\
\text { Topeng Bali }\end{array}$ & $\begin{array}{l}\text { ASTI } \\
\text { Bandung }\end{array}$ & $\begin{array}{l}2 \\
\text { Nopember } \\
1990\end{array}$ & $\begin{array}{l}\text { Team Kesenian } \\
\text { Bali }\end{array}$ \\
\hline
\end{tabular}




\begin{tabular}{|c|c|c|c|c|}
\hline 19 & $\begin{array}{l}\text { Media } \\
\text { Pembelajaran } \\
\text { Rgt. A Jurusan } \\
\text { Tari STSI } \\
\text { Surakarta: Tari } \\
\text { Palguna - } \\
\text { Palgunadi }\end{array}$ & $\begin{array}{l}\text { STSI } \\
\text { Surakarta }\end{array}$ & $\begin{array}{l}18 \\
\text { Nopember } \\
1999\end{array}$ & $\begin{array}{l}\text { Jurusan Tari } \\
\text { STSI Surakarta }\end{array}$ \\
\hline 20 & $\begin{array}{l}\text { Media } \\
\text { Pembelajaran } \\
\text { Rgt. A Jurusan } \\
\text { Tari STSI } \\
\text { Surakarta: Tari } \\
\text { Tandingan } \\
\text { Gagah }\end{array}$ & $\begin{array}{l}\text { STSI } \\
\text { Surakarta }\end{array}$ & $\begin{array}{l}18 \\
\text { Nopember } \\
1999\end{array}$ & $\begin{array}{l}\text { Jurusan Tari } \\
\text { STSI Surakarta }\end{array}$ \\
\hline 21 & $\begin{array}{l}\text { Pentas Kesenian } \\
\text { Daerah } \\
\text { Istimewa } \\
\text { Yogyakarta: } \\
\text { Langen } \\
\text { Mandrawanara } \\
\text { "Kumbakarno } \\
\text { Gugur" }\end{array}$ & $\begin{array}{l}\text { Ndalem } \\
\text { Kepatihan } \\
\text { Yogyakarta }\end{array}$ & $\begin{array}{l}13 \\
\text { Desember } \\
1993\end{array}$ & $\begin{array}{l}\text { Kepatihan } \\
\text { Yogyakarta }\end{array}$ \\
\hline 22 & $\begin{array}{l}\text { Pentas Kesenian } \\
\text { Daerah } \\
\text { Istimewa } \\
\text { Yogyakarta: } \\
\text { Tari Golek } \\
\text { Layung Seto }\end{array}$ & $\begin{array}{l}\text { Ndalem } \\
\text { Kepatihan } \\
\text { Yogyakarta }\end{array}$ & $\begin{array}{l}13 \\
\text { Desember } \\
1993\end{array}$ & $\begin{array}{l}\text { Kepatihan } \\
\text { Yogyakarta }\end{array}$ \\
\hline 23 & $\begin{array}{l}\text { Dokumentasi } \\
\text { Ujian Penyajian } \\
\text { Jurusan Tari } \\
\text { STSI Surakarta: } \\
\text { Drama Tari } \\
\text { "Dewi Sawitri" }\end{array}$ & $\begin{array}{l}\text { STSI } \\
\text { Surakarta }\end{array}$ & $\begin{array}{ll}10 & \text { Mei } \\
1993 & \end{array}$ & $\begin{array}{l}\text { Any Ridarwati } \\
\text { dan Sri Rahayu } \\
\text { Ningsih }\end{array}$ \\
\hline 24 & $\begin{array}{l}\text { Dokumentasi } \\
\text { Ujian Penyajian } \\
\text { Jurusan Tari } \\
\text { STSI Surakarta: } \\
\text { Bedhaya } \\
\text { Pangkur, } \\
\text { Gambyong } \\
\text { Pangkur }\end{array}$ & $\begin{array}{l}\text { STSI } \\
\text { Surakarta }\end{array}$ & $\begin{array}{ll}10 & \text { Mei } \\
1993 & \end{array}$ & $\begin{array}{l}\text { Yulistyaningsih } \\
\text { dan Patmiyati, } \\
\text { Sri Lestari } \\
\text { Purnawirastri }\end{array}$ \\
\hline 25 & $\begin{array}{l}\text { Dokumentasi } \\
\text { Ujian Penyajian } \\
\text { Jurusan Tari } \\
\text { STSI Surakarta: }\end{array}$ & $\begin{array}{l}\text { STSI } \\
\text { Surakarta }\end{array}$ & $\begin{array}{ll}10 & \text { Mei } \\
1993 & \end{array}$ & $\begin{array}{l}\text { Wulandari } \\
\text { Intan } \\
\text { Herwinanti }\end{array}$ \\
\hline
\end{tabular}




\begin{tabular}{|c|c|c|c|c|}
\hline & $\begin{array}{l}\text { Komposisi } \\
\text { None Boto, } \\
\text { Komposisi Plot }\end{array}$ & & & \\
\hline 26 & $\begin{array}{l}\text { Dokumentasi } \\
\text { Ujian Penyajian } \\
\text { Jurusan Tari } \\
\text { STSI Surakarta: } \\
\text { Handaka - } \\
\text { Bugis, Sugriwo } \\
\text { - Subali }\end{array}$ & $\begin{array}{l}\text { STSI } \\
\text { Surakarta }\end{array}$ & $\begin{array}{l}10 \mathrm{Mei} \\
1993\end{array}$ & $\begin{array}{l}\text { Dandun Eko T } \\
\text { Slamet Sudarto }\end{array}$ \\
\hline 27 & $\begin{array}{l}\text { Dokumentasi } \\
\text { Ujian Penyajian } \\
\text { Jurusan Tari } \\
\text { STSI Surakarta: } \\
\text { Komposisi } \\
\text { Bego, } \\
\text { Komposisi } \\
\text { Solah }\end{array}$ & $\begin{array}{l}\text { STSI } \\
\text { Surakarta }\end{array}$ & $\begin{array}{l}10 \text { Mmei } \\
1993\end{array}$ & $\begin{array}{l}\text { Agus Prayitno } \\
\text { Joko Priyono }\end{array}$ \\
\hline 28 & $\begin{array}{l}\text { Dokumentasi } \\
\text { Ujian Penyajian } \\
\text { Jurusan Tari } \\
\text { STSI Surakarta: } \\
\text { Anoman Cakil, } \\
\text { Anoman } \\
\text { Kataksini }\end{array}$ & $\begin{array}{l}\text { STSI } \\
\text { Suraka }\end{array}$ & $\begin{array}{l}11 \mathrm{Mei} \\
1992\end{array}$ & $\begin{array}{l}\text { Dandun Eko T } \\
\text { Slamet Sudarto }\end{array}$ \\
\hline 29 & $\begin{array}{l}\text { Dokumentasi } \\
\text { Ujian Penyajian } \\
\text { Jurusan Tari } \\
\text { STSI Surakarta: } \\
\text { Bujangganong, } \\
\text { Jathil }\end{array}$ & $\begin{array}{l}\text { STSI } \\
\text { Surakarta }\end{array}$ & $\begin{array}{l}11 \mathrm{Mei} \\
1992\end{array}$ & $\begin{array}{l}\text { Kunik Diah AW } \\
\text { Esti Andrini }\end{array}$ \\
\hline 30 & $\begin{array}{l}\text { Dokumentasi } \\
\text { Ujian Penyajian } \\
\text { Jurusan Tari } \\
\text { STSI Surakarta: } \\
\text { Dramatari } \\
\text { Kridatama }\end{array}$ & $\begin{array}{l}\text { STSI } \\
\text { Surakarta }\end{array}$ & $\begin{array}{l}11 \mathrm{Mei} \\
1992\end{array}$ & Irmahen W.L \\
\hline 31 & $\begin{array}{l}\text { Dokumentasi } \\
\text { Ujian Penyajian } \\
\text { Jurusan Tari } \\
\text { STSI Surakarta: } \\
\text { Dramatari } \\
\text { Patibrata }\end{array}$ & $\begin{array}{l}\text { STSI } \\
\text { Surakarta }\end{array}$ & $\begin{array}{l}11 \mathrm{Mei} \\
1992\end{array}$ & $\begin{array}{l}\text { E.K Lukitasari } \\
\text { dan Titik } \\
\text { Pardiani }\end{array}$ \\
\hline
\end{tabular}




\begin{tabular}{|c|c|c|c|c|}
\hline 32 & $\begin{array}{l}\text { Dokumentasi } \\
\text { Ujian Penyajian } \\
\text { Jurusan Tari } \\
\text { STSI Surakarta: } \\
\text { Priyambodo } \\
\text { Mustakaweni, } \\
\text { Srimpi } \\
\text { Sangupati }\end{array}$ & $\begin{array}{l}\text { STSI } \\
\text { Surakarta }\end{array}$ & $\begin{array}{l}11 \text { Mei } \\
1992\end{array}$ & $\begin{array}{l}\text { Sri Lestari P } \\
\text { Yulistyaningsih } \\
\text { dan Patmiyati }\end{array}$ \\
\hline 33 & $\begin{array}{l}\text { Dokumentasi } \\
\text { Wayang } \\
\text { Topeng Dalang } \\
\text { Klaten: Joko } \\
\text { Bluwo }\end{array}$ & $\begin{array}{l}\text { STSI } \\
\text { Surakarta }\end{array}$ & $\begin{array}{ll}14 & \text { Mei } \\
1991 & \end{array}$ & $\begin{array}{l}\text { Gondo Sukasno } \\
\text { (Tukas) }\end{array}$ \\
\hline 34 & $\begin{array}{l}\text { Asean Cultural } \\
\text { Tradisional } \\
\text { Media Festival } \\
\text { Lakon : Nyai } \\
\text { Ageng Serang } \\
\text { Naskah : Edy } \\
\text { Sulistyana } \\
\text { Karawitan : } \\
\text { Sudarso }\end{array}$ & $\begin{array}{l}\text { STSI } \\
\text { Surakarta }\end{array}$ & $\begin{array}{l}10 \\
\text { Agustus } \\
1995\end{array}$ & $\begin{array}{l}\text { Indonesa / STSI } \\
\text { Surakarta }\end{array}$ \\
\hline
\end{tabular}

Kaset video di atas merupakan koleksi perpustakaan ISI Surakarta, kaset video tersebut dipilih peneliti untuk dipreservasi karena dianggap sebagai koleksi langka. Seluruh kaset video yang dipilih telah berusia 20 sampai 30 tahun, dan alat pemutarnya sudah tidak tersedia di perpustakaan maupun di pasaran.

\section{Melakukan koordinasi dengan pustakawan pelaksana preservasi}

Tujuan utama program preservasi kaset video adalah mengusahakan agar koleksi kaset video selalu sedia dan siap pakai. Hal ini dapat dilakukan dengan melestarikan bentuk fisik kaset video, melestarikan kandungan informasi ke dalam media lain (alih media) seperti CD maupun VCD dan DVD, atau melestarikan kedua-duanya, yaitu bentuk fisik dan kandungan informasi. 
Tujuan kebijaksanaan pelestarian dirumuskan sebagai berikut:

a) Melestarikan kandungan informasi ilmiah yang direkam dan dialihkan pada media lain.

b) Melestarikan bentuk fisik asli bahan pustaka dan arsip sehungga dapat digunakan dalam bentuk seutuh mungkin (Dureau dan Clements, 1990: 2)

Koordinasi dengan pustakawan yang lain perlu dilakukan, agar ada persamaan persepsi tentang preservasi terhadap koleksi kaset video. Mengingat bahwa preservasi terhadap koleksi kaset video tidak diprogramkan oleh UPT perpustakaan ISI Surakarta. Hal itu bisa dilihat dari anggaran yang disetujui oleh pihak pimpinan bahwa pengusulan preservasi tidak pernah muncul. Kegiatan perservasi yang disetujui masih berkutat pada perbaikan bahan pustaka yang diartikan hanya untuk memperbaiki buku-buku yang rusak saja. Padahal arti perbaikan bahan pustaka sebenarnya memiliki cakupan yang luas, yaitu seluruh bahan pustaka yang dimiliki UPT perpustakaan ISI Surakarta perlu diperbaiki. Termasuk di dalamnya bahan-bahan digital, audio dan video.

Dalam koordinasi dengan pustakawan lain, yang perlu dibahas adalah sebagai berkit :

a) Menentukan kapan dimulainya dan berakhirnya kegiatan preservasi koleksi kaset video.

b) Menentukan langkah-langkah preservasi koleksi secara umum.

c) Menentukan cara yang tepat dan efisien untuk preservasi koleksi kaset video.

d) Mencari dan mengusahakan alat-alat yang dibutuhkan dalam preservasi koleksi kaset video

e) Merencakan cara melayankan koleksi kaset video agar dapat dinikmati oleh pemustaka pasca preservasi koleksi kaset video.

Dalam standar pelestarian bahan pustaka pada pengawasan lingkungan perlu diperhatikan suatu suhu penyimpanan bahan pustaka. Berbagai literatur barat mengatakan bahwa suhu yang ideal untuk penyimpanan bahan pustaka 
berkisar 20 derajat sampai 21 derajat dengan kelembaban nisbi sekitar $50 \%$. Suhu sekitar 20-21 derajat dapat dikompromikan antara kenyamanan pemakai perpustakaan dengan keperluan bahan pustaka. Dalam prakteknya, semakin rendah suhu ruangan semakin baik bagi pengawetan bahan pustaka. Suhu rendah ini berkisar antara sekitar 10 derajat. Sebenarnya perlu pemisahan antara ruangan penyimpanan buku (berupa rak) dengan ruangan umum. Dengan demikian pada ruangan penyimpanan suhu dapat dibuat rendah sementara untuk pemakai dapat dinaikkan sekitar 20 derajat. Bagi daerah tropis seperti Indonesia pengaturan kelembaban gedung perpustakaan perlu diperhatikan. Perubahan kelembaban diusahakan tidak terlalu besar (Sulistiyo-Basuki, 1994:271).

Maksud pelestarian ialah mengusahakan agar bahan pustaka tidak cepat mengalami kerusakan. Bahan pustaka yang mahal, diusahakan agar awet, dan bisa tahan lama. Tujuan pelestarian bahan pustaka adalah:

a) Menyelamatkan nilai informasi yang terkandung dalam setiap bahan pustaka atau dokumen.

b) Menyelamatkan bentuk fisik bahan pustaka atau dokumen.

c) Mengatasi kendala kekurangan ruang

d) Mempercepat proses temu balik atau penelusuran dan perolehan informasi.

e) Menjaga keindahan dan kerapian bahan pustaka.

f) Mencegah koleksi perpustakaan dari kerusakan akibat penggunaan yang keliru oleh mahasiswa (Ibrahim, 2014: 37).

\section{Mempersiapkan peralatan preservasi}

Proses preservasi memerlukan penanganan yang khusus, harus melalui tahapan-tahapan preservasi, tahapan pra alih media yang biasanya dilakukan persiapan, antara lain :

a) Mempersiapkan daftar koleksi kaset video yang akan dipreservasi

b) Memilih koleksi yang diprioritaskan atau yang diutamakan yang sangat mendesak sebagai media pembelajaran di ISI Surakarta.

c) Memilih sumber daya manusia yang ahli di bidang preservasi. 
d) Diperlukan peralatan yang lebih baik khususnya pada komputer dengan spesifikasi yang tinggi, antara lain:

1) RAM 4 GB

2) VGA $1 \mathrm{~GB}$

3) Harddisk 2 Tera

4) CD-ROM yang berkualitas

5) Sound Card firewire

Sumber

https://www.google.com/search?q=firewire+to+usb\&safe=strict\&rlz=1C1RL NS enID716ID716\&sxsrf=ACYBGNRwQArUloldeEOCti8yDpcJtLoTlg:1570670 191693\&source=Inms\&tbm=isch\&sa=X\&ved=0ahUKEwj47Na2wpDIAhWMY o8KHdB C3sQ AUIESgB\&biw=1366\&bih=576\#imgrc= yCOBf8zhSAwNM:

6) Player Video 8

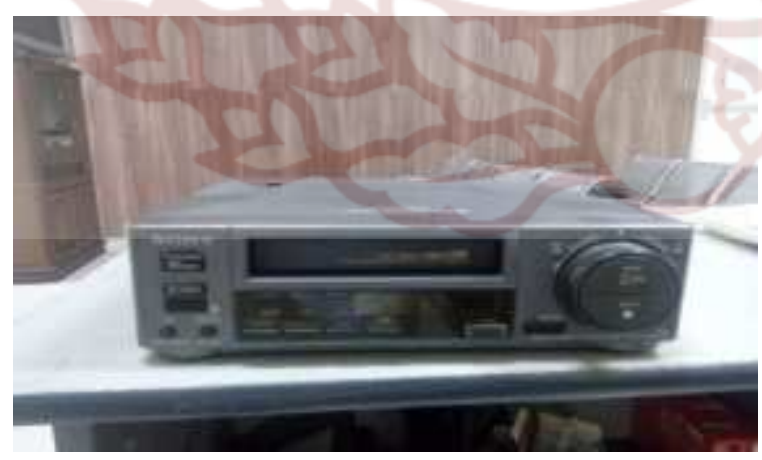

Sumber : Dokumentasi Perpustakaan ISI Surakarta

e) Persiapan Infrastuktur

1) Pengecekan pada alat yang akan dipergunakan untuk preservasi.

2) Menyiapkan tempat yang cukup memadai agar kegiatan dapat dilakukan dengan nyaman. 
3) Pengecekan instalasi listrik sebagai sarana penunjang komputer yang akan dipergunakan untuk preservasi.

4) Menyiapkan tempat penyimpanan database termasuk server berikut kualitas dan kuantitas.

\section{Melaksanakan proses preservasi Melaui Alih Media}

Preservasi Bahan Pustaka digital adalah proses memilih, mengadakan, mengolah, melayankan, serta memelihara dokumen atau data digital sehingga dapat dimanfaatkan dalam waktu yang lama secara internal oleh publik sesuai dengan kaidah, norma dan kode etik yang berlaku. Mustafa (2008). Preservasi adalah semua kegiatan yang bertujuan memperpanjang umur bahan pustaka dan informasi yang ada di dalamnya. Purwono (2009:217). Selain itu definisi lain juga menyebutkan preservasi digital adalah upaya memastikan agar materi digital tidak bergantung pada kerusakan dan perubahan teknologi. Secara umum preservasi digital mencakup berbagai bentuk kegiatan, mulai dari kegiatan sederhana menciptakan tiruan (replika atau copy) dari sebuah materi digital untuk disimpan, sampai kegiatan transformasi digital yang cenderung rumit. Pendit (2008:248).

Cara pengaplikasian software VEGAS Pro 16.0 dalam proses alih media koleksi kaset video ke dalam bentuk digital pada UPT Perpustakaan ISI Surakarta.

a. Tahap Pelaksanaan Alih Media

Tahap pelaksanaan merupakan inti dari kegiatan preservasi melalui alih media. Hal-hal yang dilakukan dalam pelaksanaan ini antara lain sebagai berikut :

1) Mengambil koleksi yang telah didata atau masuk dalam daftar koleksi yang akan diprseservasi melalui alihmedia.

2) Mempersiapkan Player Video Cassette Recorder Hi 8.

3) Menghubungkan Player Video Cassette Recorder Hi 8 dengan komputer agar terjalin konektivitas. 
4) Membuka program / software VEGAS Pro 16.0 untuk pelaksanaan alih media.

5) Melakukan kegiatan tahap record audiovisual yaitu merekam data dari kaset video analog ke dalam komputer dengan alat Player Video Cassette Recorder Hi 8 dan juga software VEGAS Pro 16.0.

6) Mengedit hasil rekaman agar bersih dari gambar visual yang diperlukan dan menambah watermark sebagai identitas kepemilikan lembaga, memberi judul agar sesuai kontentnya .

7) Setelah proses editing selesai dilanjutkan proses rendering untuk dijadikan ke format yang sesuai dengan kebutuhan lembaga, seperti format : MP4, VCD, DVD, dll.

8) Menyimpan ke dalam hardisk.

9) Burning ke dalam Compact Disc (CD) dengan menggunakan software Nero.

b. Tahapan Alih Media menggunakan Software VEGAS Pro 16.0

1. Membuka program/software VEGAS Pro 16.0

Menekan di layar dekstop yang terdapat logo V warna hitam (klik 2 kali), maka akan muncul tampilan dibawah ini. Pada tampilan awal akan muncul 3 tampilan utama, yaitu a) Import Media, yang berfungsi untuk mengambil data yang tersimpan di suatu folder dalam komputer. b) Video Priview, yang berfungsi untuk menampilkan viual dalam layar c) Tampilan Video track, yang berfungsi untuk menampilkan gambar dan suara yang terdapat dalam kaset video. 


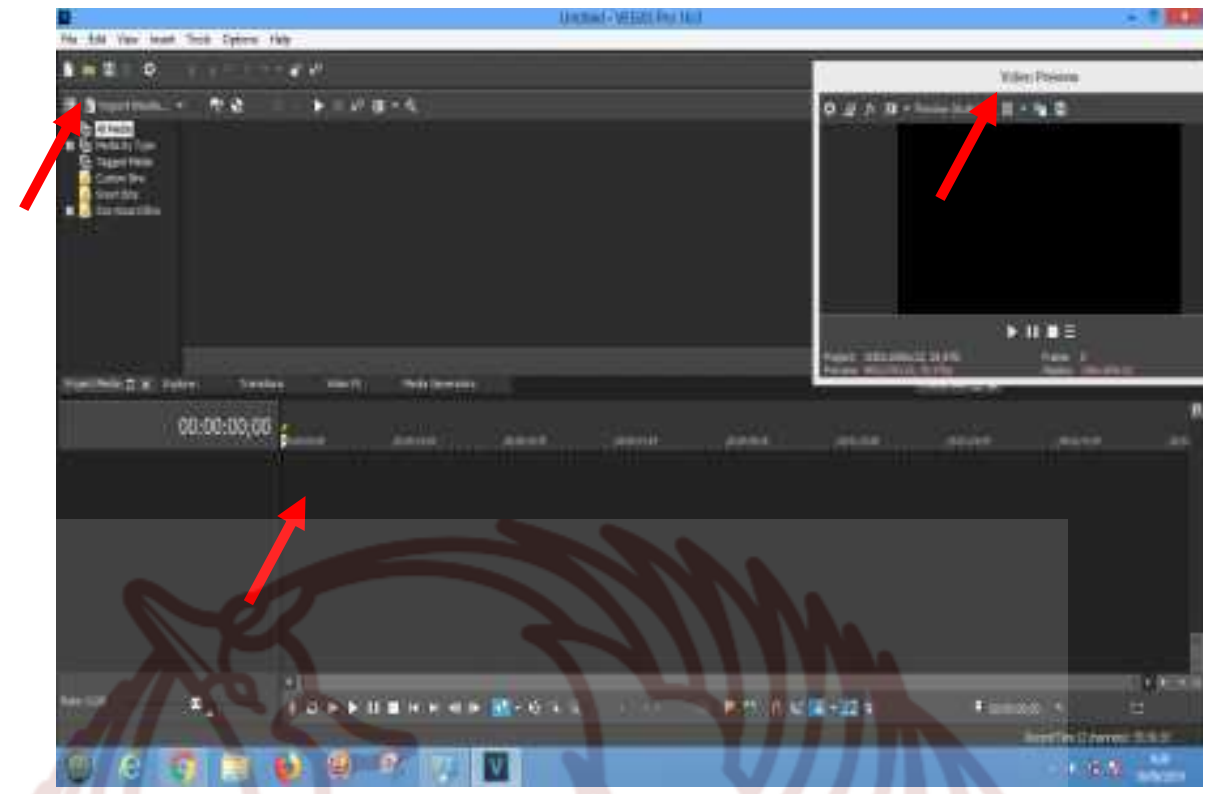

Gambar 1. Tampilan Menu Utama Software VEGAS Pro 16.0

2. Mencapture koleksi video yang dialih mediakan

Menekan / klik menu file, selanjutnya akan muncul beberapa fasilitas. Maka dipilih menu capture video. Menu ini untuk menampilkan menu pemilihan format gambar video yang akan dicapture.

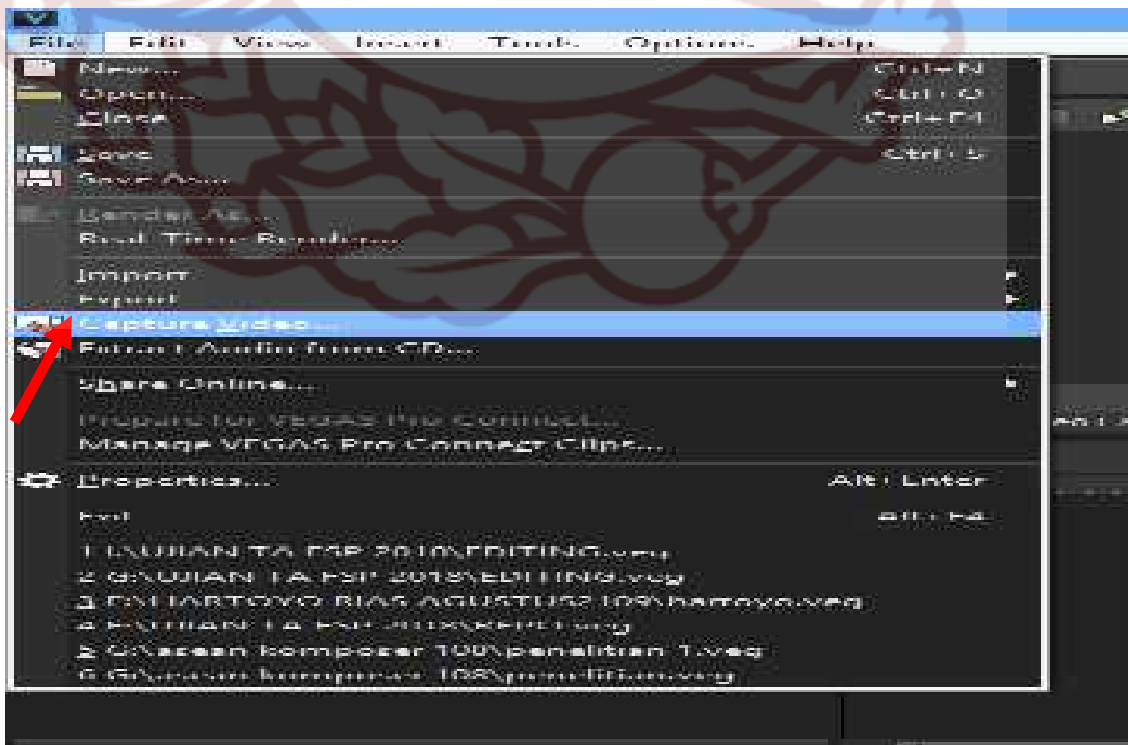

Gambar 2 : Capture Kaset Video 


\section{Pemilihan Format Video}

Dalam tampilan ini akan muncul pilihan cature video dengan 2 format, yaitu a) Format DV, artinya bahwa format ini merupakan format video standart dunia, yang banyak digunakan oleh berbagai kalangan rumahan, semi profesional, profesional hingga para cineas. b) Format HDV (High Devinition Video) atau SDI, artinya bahwa format menghasilkan tampilan gambar yang lebih bagus dari format DV. Setelah memilih salah satu yang dikehendaki maka selanjutkan klik (OK).

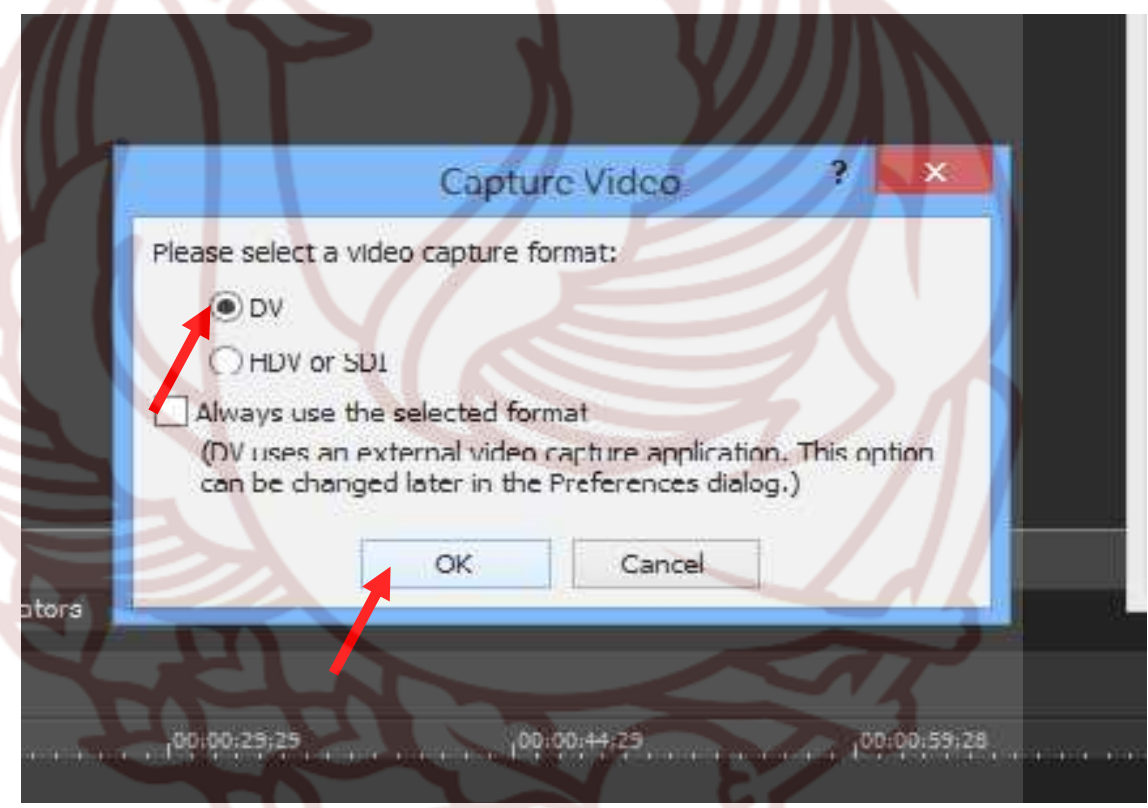

Gambar 3: Pemilihan Format Video

\section{Proses Capture Video}

Pilih menu OK pada tampilan Capture video setelah memilih format hasil video yang diinginkan. Pada bagian akan muncul tampilan video yang dialihmediakan kemudiakan klik "capture video". Apabila proses capture selesai maka klik tombol STOP. Ini brarti proses capture kaset video telah sempurna dan file baru dari hasil tersebut akan disimpan di Folder Komputer atau External Hardisk. 


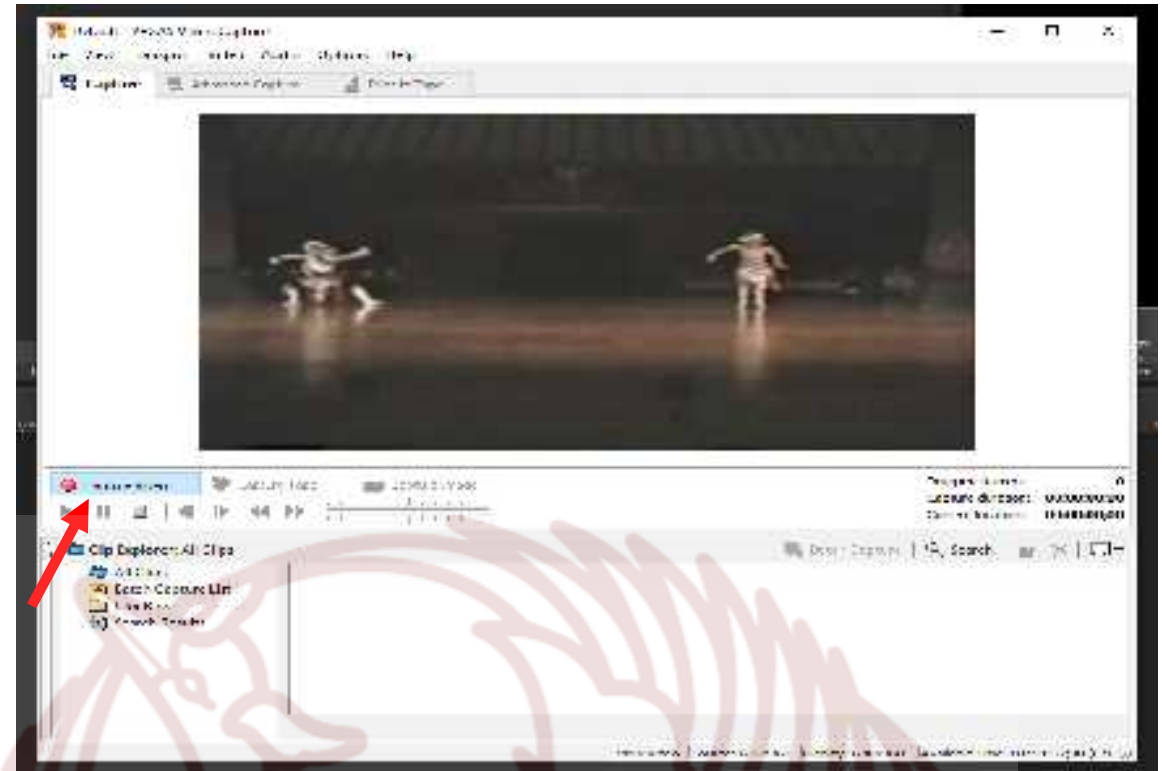

Gambar 4: Tampilan Preview Capture

5. Proses Pembuatan Menu Editing

Kembali ke tampilan menu awal, kemudia klik File - New maka akan muncul tampilan New Project. Setelah itu Pilih Template untuk menentukan file tersebut ke format yang dikehendaki untuk disimpan, contoh: memilih format HD, HDV, dsb. Lihat gambar 5. Kemudian klik fasilitas Browse untuk memilih tempat penyimpanan file video yang dikehendaki serta untuk memberi nama file projectnya. Kemudian klik OK. Contoh: File Project disimpan di Computer dan diberi nama Folder Preservasi Kaset Video, lihat gambar 6. 


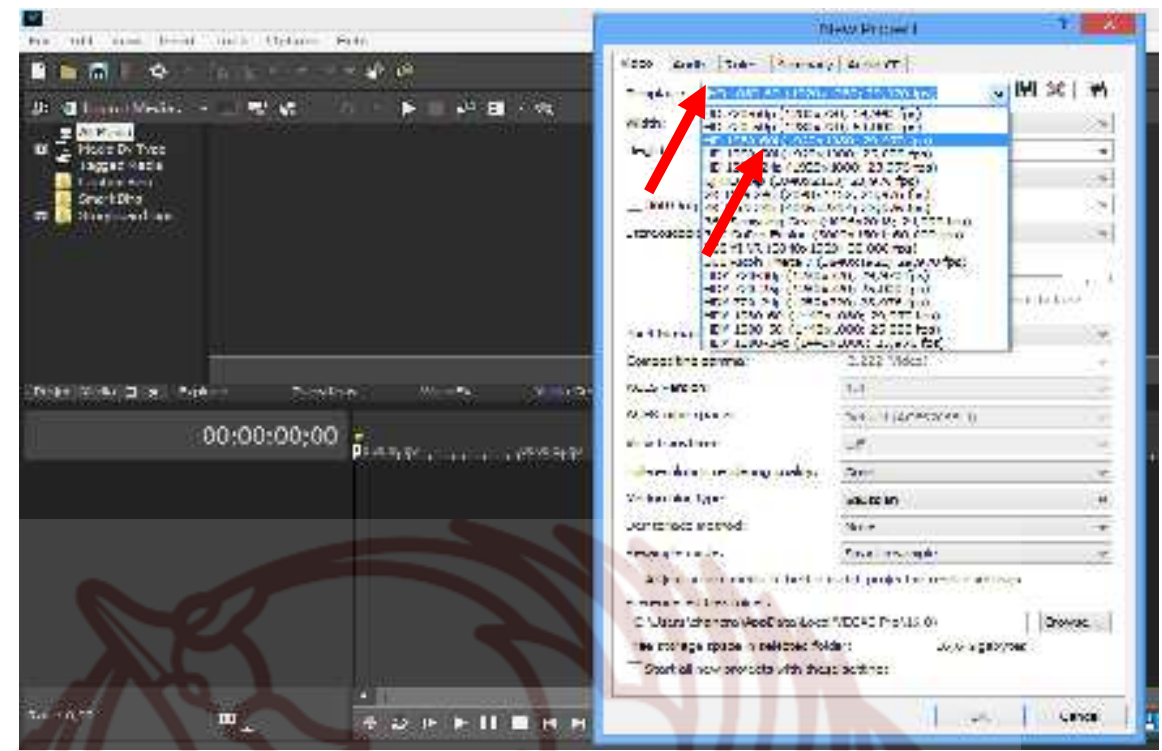

Gambar 5. Memilih Format Video HD / HDV

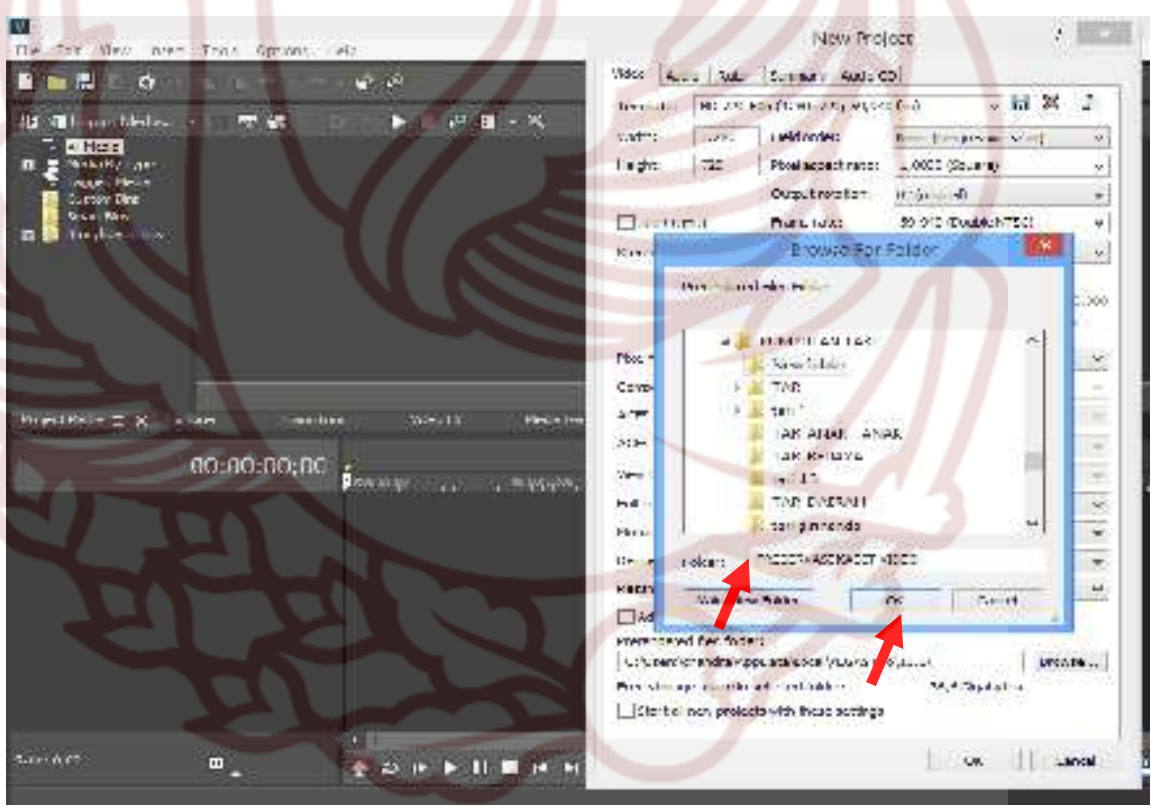

Gambar 6. Memilih Tempat Penyimpanan File Project

\section{Proses Import Data Video}

Setelah proses pembuatan file menu editing maka diteruskan dengan proses Import Data Video, hal ini dilakukan sebelum proses editing dimulai, yaitu dengan langkah kembali ke menu utama, kemudian klik menu File selanjutnya pilih fasilitas import dan dilanjutkan klik media. Ini adalah sebagai langkah awal dalam proses editing. 


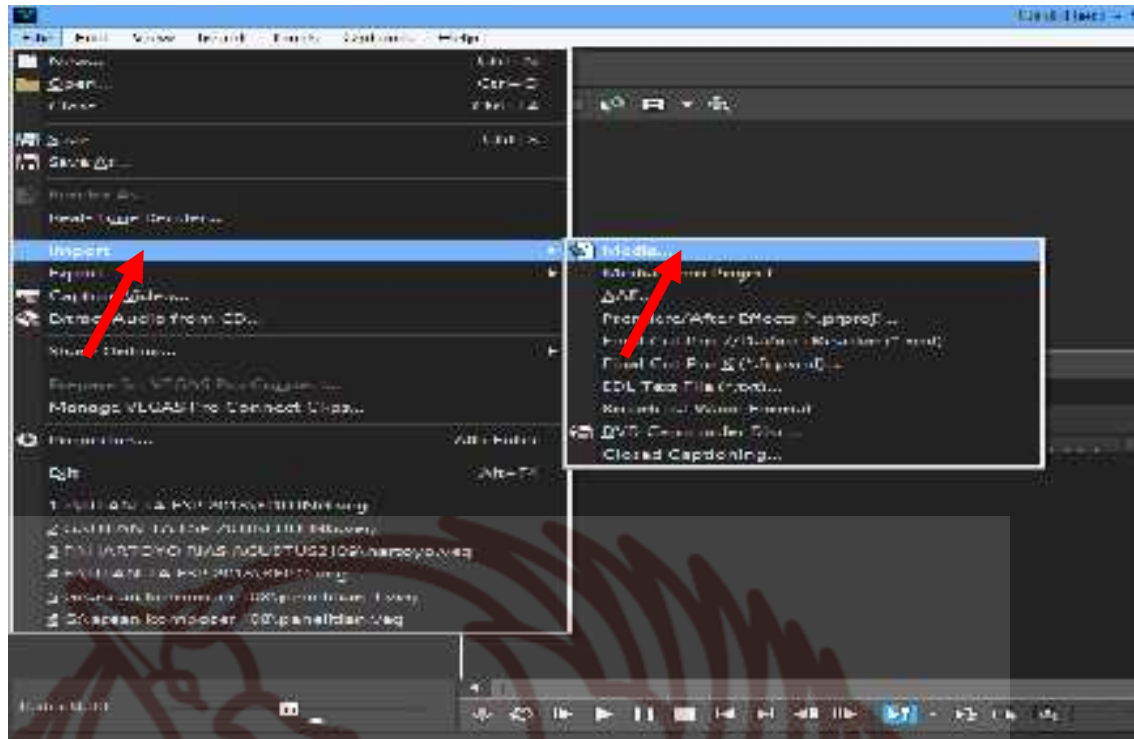

Gambar 7: Import Data Video

7. Pengambilan File Dokumen Video

Setelah klik fasilitas (media) dalam proses import data maka akan menunjukkan letak tersimpannya file dalam suatu forder. Setelah file yang mau di edit ditemukan maka klik 2 kali / tekan satu kali trus klik tombol open pada nama file tersebut.

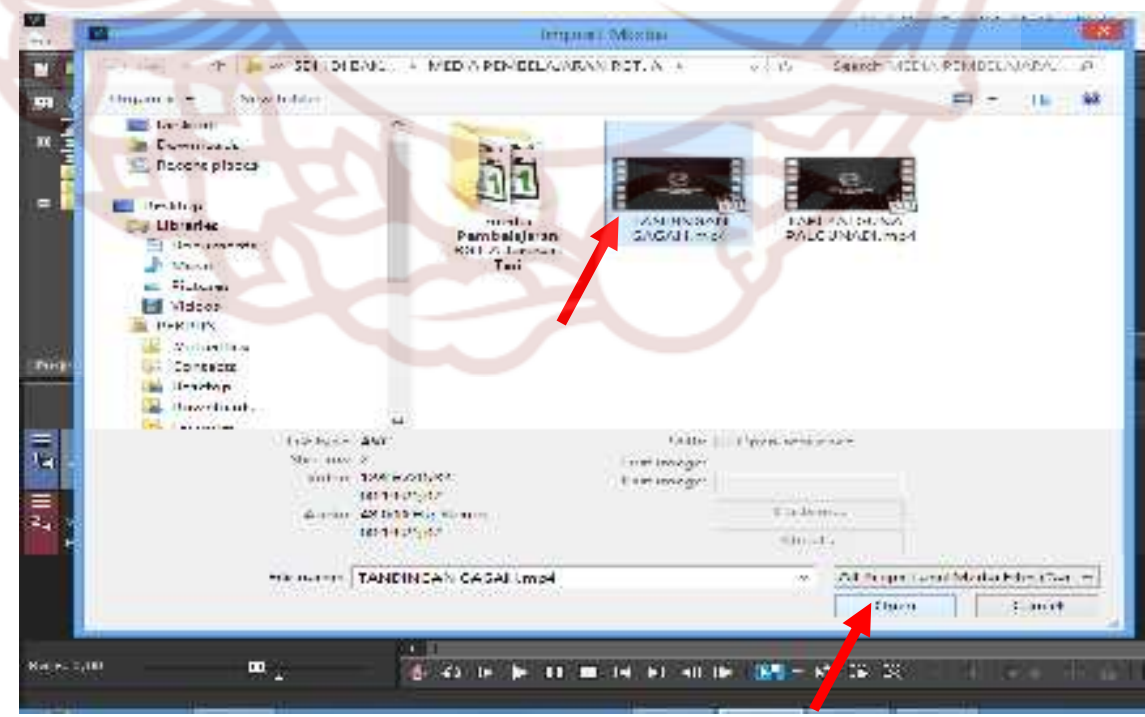

Gambar 8 : Pengambilan File Dokumen 


\section{Proses Editing Video}

a) Setelah File Video dibuka, maka muncul tampilan kecil di project media kemudian untuk melihat preview file video maka langkah selanjutnya yaitu didrak ke bagian timeline. Maka selanjutnya pilih Yes untuk memunculkan gambar video dan suaranya.

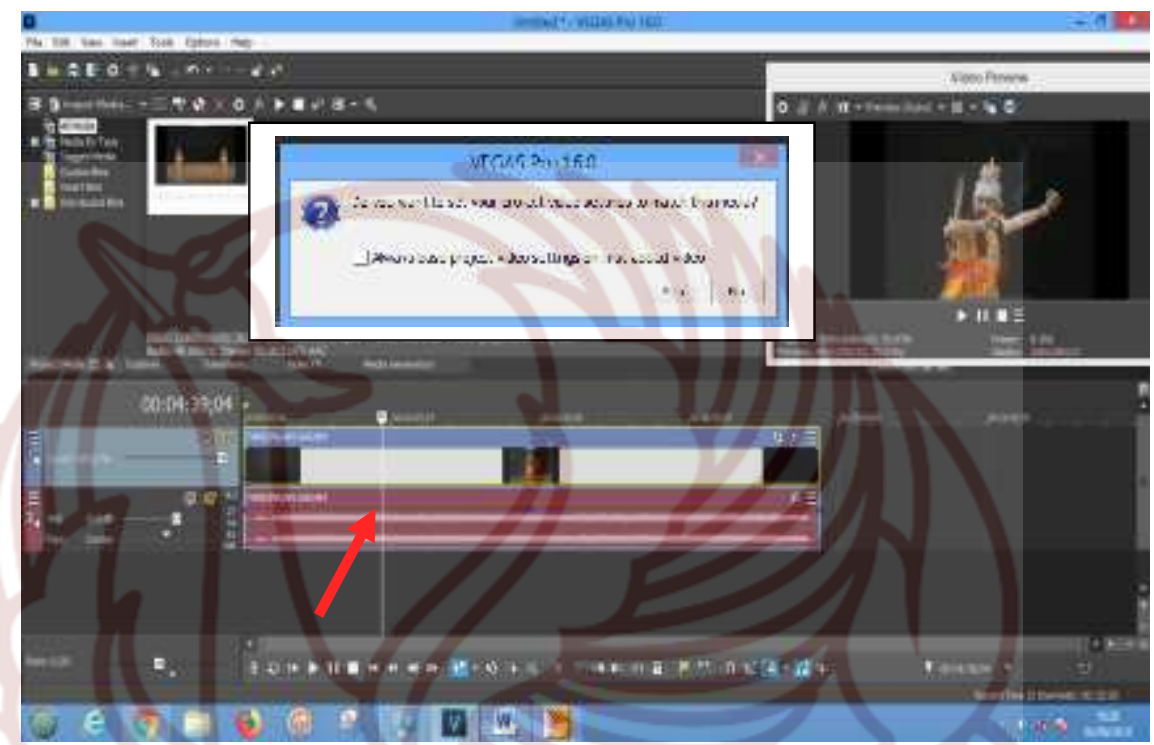

Gambar 9. Proses Editing

b) Setelah File Video dibuka maka muncul di tampilan di preview . Kemudian kita play di video preview untuk melihat hasil dokumen ada yang rusak atau tidak. Klo ada yang rusak maka file di potong ( edit ). Adapun langkah - langkahnya sebagai berikut : cursor diarahkan ke video yang akan dipotong kemudian tekan tombol ( $\mathrm{S}$ ) setelah itu file yang dipotong di klik terus tekan delete. Setelah file editing sudah jadi kita tinggal ngasih judul dan watermark. 


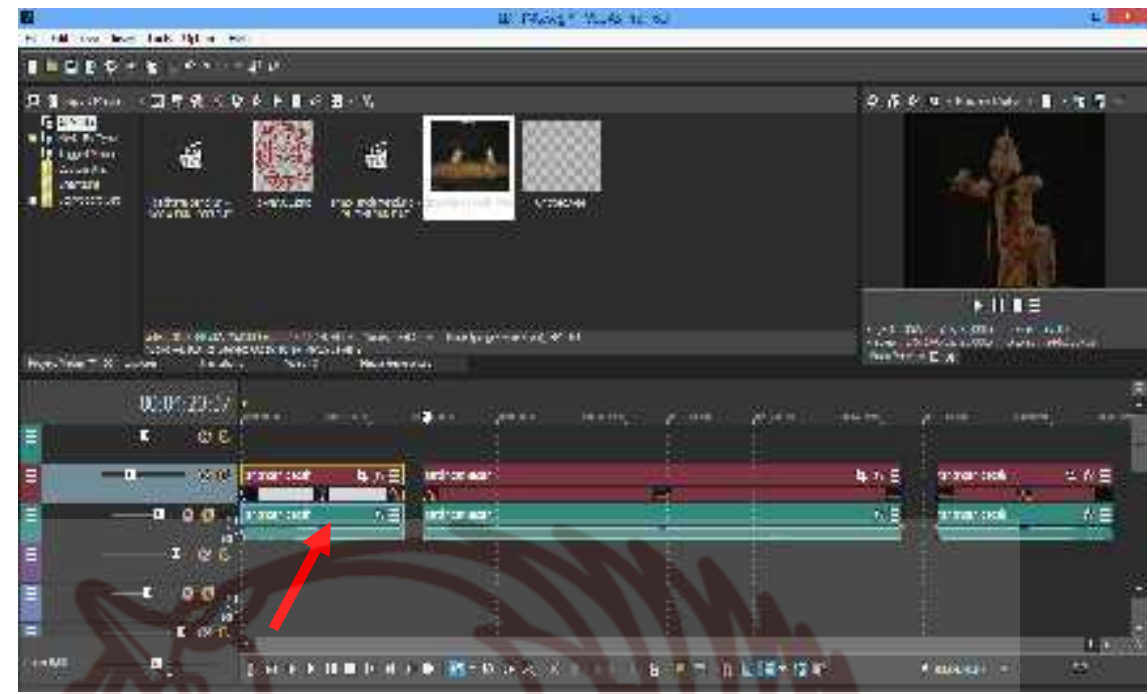

Gambar 10. Proses Editing

c) Setelah file editing sudah jadi langkah selanjutnya kita memberi judul dan watermark. Adapun langkah - langkahnya sebagai berikut : Klik insert - video trak - tekan ok. Setelah itu kita import logo / watermark. Kemudian logo di tarik ke arah menu timeline.

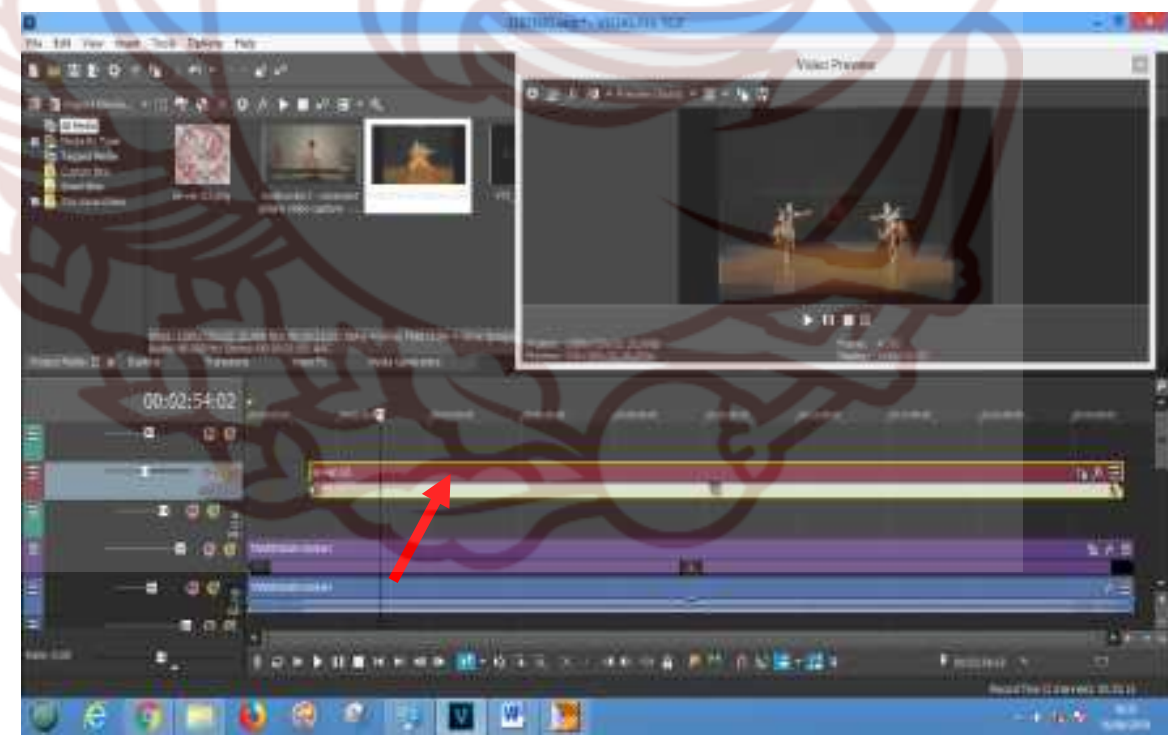

Gambar 11: Kasih watermark (logo ISI Ska)

\section{Proses Rendering Video}

a) Setelah file editing sudah dikasih judul dan watermark langkah selanjutnya file video di render. Adapun langkah - langkahnya sebagai berikut : gambar video di klik 2 kali, setelah itu tekan file klik render as. Setelah itu kita memilih format video yang kita 
inginkan ( HD, HDV, dsb ) dan dikasih nama file serta mau disimpan dimana hasil video tersebut. Kemudian tekan OK / Render

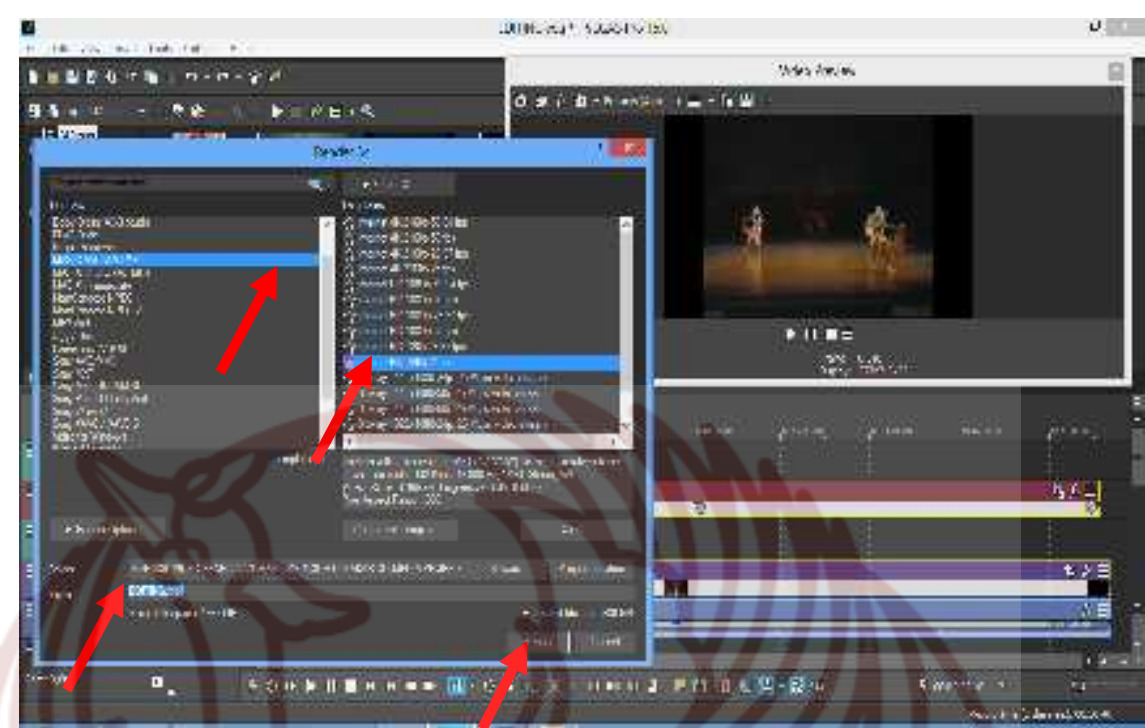

Gambar 12: Proses rendering

b) Setelah tekan OK / Render kita tinggal menunggu sampai proses rendering selesai

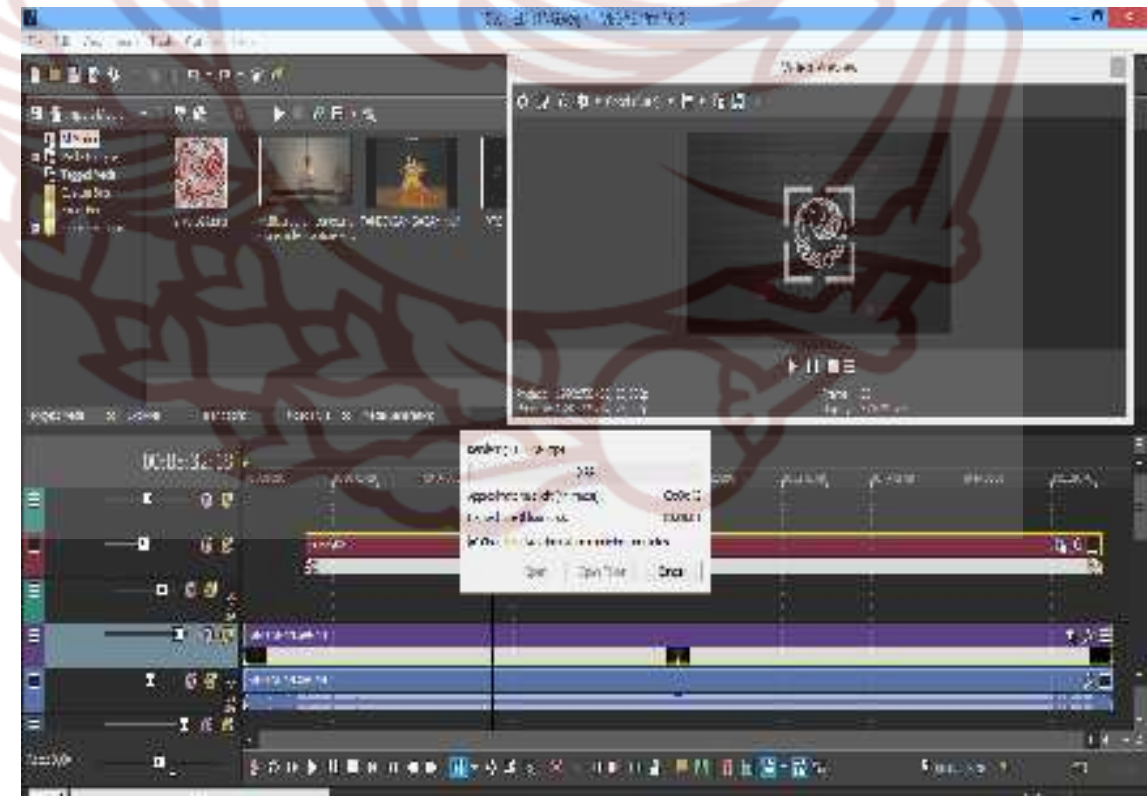

Gambar 13 : proses rendering

\section{c. Tahap Pasca Pelaksanaan Alih Media}

Setelah pekerjaan preservasi melalui alih media selesai dikerjakan, tahap selanjutnya yang harus diperhatikan adalah : 
1) Lokasi, hasil preservasi melalui alih media yang sudah menjadi digital dan disimpan di dalam CD ditempatkan pada rak koleksi Audio Visual.

2) Sistem/cara layanan, sistem layanan tetap menggunakn sistem tertutup, untuk menjaga keberadaan koleksi dan jumlah koleksi.

3) Peraturan, batasan peminjaman hanya boleh dua kaset saja, tidak boleh dibawa pulang tetapi bisa dikopi/digandakan.

\section{Hambatan Dalam Melakukan Preservasi Koleksi Kaset Video}

Di dalam preservasi koleksi kaset video di UPT Perpustakaan ISI Surakarta mengalami beberapa kendala. Adapun kendala yang dialami petugas pada kegiatan preservasi koleksi kaset video adalah : a) Koleksi kaset video sebagian ada yang sudah putus. b) Koleksi kaset video banyak yang sudah tidak bisa diputar karena berjamur. c) Kurangnya kesadaran lembaga untuk turut menjaga koleksi kaset video. d) Kurangnya anggaran dana untuk preservasi kaset video. e) Belum memiliki SOP tentang preservasi koleksi khususnya kaset video. f) Tidak ada kegiatan sosialisasi preservasi kaset video. g) Sudah tidak memiliki player sebagai alat alih media kaset video. h) Serta belum memiliki tenaga pengelola pustakawan professional. 


\section{BAB V. \\ PENUTUP}

\section{A. Kesimpulan}

Tujuan preservasi kaset video sebenarnya adalah memastikan informasi yang tersimpan dalam media kaset video tersebut tetap dapat diakses oleh siapapun yang memerlukannya baik di masa kini ataupun di masa yang akan datang. Karena itu ketika akan melakukan preservasi kaset video, hendaknya sudah dipikirkan pula metode preservasi yang akan dilakukan. Indonesia dikenal sebagai bangsa yang senang membuat atau membangun sesuatu yang bagus dan menarik akan tetapi tidak pandai merawatnya sehingga akhirnya menjadi rusak.

Proses preservasi memerlukan penanganan yang khusus, harus melalui tahapan-tahapan preservasi, tahapan pra alih media yang biasanya dilakukan persiapan, antara lain: 1) Mempersiapkan daftar koleksi kaset video yang akan dipreservasi 2) Memilih koleksi yang diprioritaskan atau yang diutamakan yang sangat mendesak sebagai media pembelajaran di ISI Surakarta. 3) Memilih sumber daya manusia yang ahli di bidang preservasi. 4) Diperlukan peralatan yang lebih baik khususnya pada komputer dengan spesifikasi yang tinggi 5) Persiapan Infrasruktur.

Strategi preservasi yang dilakukan oleh UPT Perpustakaan ISI Surakarta adalah dengan cara alih media dari koleksi kaset video ke dalam bentuk digital, alih media ini terdiri dari 9 tahapan dan menggunakan Software VEGAS Pro 16.0. Adapun tahapan-tahapan dalam alih media kaset video adalah sebagai berikut: 1) Membuka program/software VEGAS Pro 16.0. 2) Mencapture koleksi video yang dialih mediakan. 3) Pemilihan Format Video. 4) Proses Capture Video. 5) Proses Pembuatan Menu Editing. 6) Proses Import Data Video. 7) Pengambilan File Dokumen Video. 8) Proses Editing Video. 9) Proses Rendering Video. 
Setelah pekerjaan preservasi melalui alih media selesai dikerjakan, tahap selanjutnya yang harus diperhatikan adalah : 1) Lokasi, hasil preservasi melalui alih media yang sudah menjadi digital dan disimpan di dalam CD ditempatkan pada rak koleksi Audio Visual. 2) Sistem/cara layanan, sistem layanan tetap menggunakn sistem tertutup, untuk menjaga keberadaan koleksi dan jumlah koleksi. 3) Peraturan, batasan peminjaman hanya boleh dua kaset saja, tidak boleh dibawa pulang tetapi bisa dikopi/digandakan.

\section{B. Saran}

Dari hasil penelitian di atas, maka saran peneliti adalah :

1) Menyediakan anggaran rutin (setiap tahun) khusus untuk preservasi koleksi kaset video.

2) Mengadakan sosialisasi preservasi koleksi kaset video dan menghadirkan para stakeholder.

3) UPT Perpustakaan ISI Surakarta hendaknya segera membuat SOP tentang preservasi koleksi khususnya kaset video.

4) Pengadaan / membeli player video 8 sebagai alat alih media kaset video.

5) Melatih / mengikutkan diklat preservasi kepada staff perpustakaan di Perpusnas agar menjadi tenaga pengelola pustakawan professional dalam hal preservasi. 


\section{DAFTAR PUSTAKA}

Alfiah Aprilyani. "Peran Pelestarian Bahan Pustaka Dalam Preservasi dan Konservasi Badan Perpustakaan dan Arsip Daerah Istimewa Yogyakarta" Skripsi. Yogyakarta : Fakultas Adab Ilmu Budaya UIN Sunan Kalijaga, 2012.

Almah, Hildawati. Pemilihan dan Pengembangan Koleksi Perpustakaan. Makassar: Alauddin University Press, 2012.

Ambo Upe dan Damsid. Asas-asas Multiple Researches. Yogyakarta: Tiara Wacana, 2010.

Arikunto, Suharsimi. Prosedur Penelitian : Suatu Pendekatan Praktek. Jakarta : Rineka Cpta, 2010.

Beth Oehlerts and Shu Liu. "Digital Preservation Strategies at Colorado State University Library". Library Management, Vol. 34 Iss 1/2, 2013, pp. 83-95.

Chowdhury, G.G dan Sudatta Chowdhury, Introduction to Digital Libraries, London : Facet Publishing.

Darmono. Kebutuhan dan Perilaku Pencarian Informasi Penunjang Studi Mahasiswa Pascasarjana: Studi Kasus di Dua Perguruan Tinggi Penyelenggara Program Pasca Sarjana di Malang. Dalam Buletin FK2PT, Th. VI,No.1-2. 2001.

Emzir, Metodologi Penelitian Kualitatif : Analisis Data, Jakarta: Rajawali Pers,

Ed. 1, Cet. 4. 2104.

Ervina Rutami Raja Guk-guk, Kegiatan Preservasi dan Konservasi Bahan Pustaka Pada Perpustakaan Universitas HKBP Nomensen Medan, Skripsi, Medan: Departemen Ilmu Perpustakaan dan Informasi Univ. Sumatera Utara Fak. Ilmu Budaya, 2018.

Indonesia, Departemen Pendidikan nasional. 2002. Kamus Besar Bahasa Indonesia: Ed. Ketiga. Jakarta: Balai Pustaka.

Ibrahim, Andi. Pelestarian Bahan Pustaka. Makassar: Alauddin University Press, 2014.

Joan M. Reitz, ODLIS: Online Dictinary of Library and Information science, 2002 . 
LasaHs. Kamus Kepustakawanan Indonesia, Yogyakarta: Pustaka Book Publisher, 2009

Lazinger, Susan S. Digital Preservation and Metadata: History, Teory and Practice. Colorado: Libraries Unlimited, 2001.

Moleong, Lexy J. Metodelogi Penelitian Kualitatif, Bandung: Rosela Karya, 2005.

Mustafa. B. Materi Kuliah Preservasi Dokumen Digital, Bogor: Program S2 MTIP IPB, 2008.

Najla Semple, "Developing a digital preservation strategy at Edinburgh University Library", VINE, Vol. 34 Iss 1,2004, pp. 33 - 37.

Niputu Wahyu Candra Widhiandari, "Preservasi Naskah Lontar di Perpustakaan Universitas Indonesia" Skripsi, Depok : Fakultas Ilmu Pengetahuan Budaya Program Studi Ilmu Perpustakaan, 2012.

Nurjananh, "Preservasi dan Konservasi Bahan Pustaka dan Arsip Pasca Tsunami di Badan Arsip dan Perpustakaan Aceh", Tesis. Yogyakarta : Program Pascasarjana UIN Sunan Kalijaga Program Studi Interdisciplinary Islamic Studies Konsentrasi Ilmu Perpustakaan dan Informasi, 2014.

Pendit, Putu Laxman. Perpustakaan Digital dari A sampai Z. Jakarta : Cita Karyakarsa Mandiri, 2008.

PP. Nomor 88 Tahun 1999 Tentang Tata Cara Pengalihan Dokumen Perusahaan ke dalam mikrofilm atau media lainnya

Purwono, Dasar-dasar Dokumentasi : Pelestarian Dokumen. Jakarta : Universitas Terbuka, 2009.

Sarah B. WatsteinPascal V. CalarcoJames S. Ghaphery, "Digital library: keywords", Reference Services Review, Vol. 27. 1999. Iss 4 pp. $344-352$.

Stielow, Frederick. 2004. A How to do it manual for Archivist and librarian: Building digital archives, description and display. New York: Neal-Schuman Publisher.

Sutarno. HS Perpustakaan dan Masyarakat. Jakarta: Sagung Seto, 2006

Tim Redaksi Kamus Besar Bahasa Indonesia, Kamus Besar Bahasa Indonesia, Ed. $\mathrm{Ke}-4$, Jakarta : badang Pengembangan dan Pembinaan Bahasa Kementerian Pendidikan dan Kebudayaan, 2017. 
Wendy Smith dalam Purwono, 2009. Dasar-dasar Dokumentasi : Pelestarian Dokumen. Jakarta : Universitas Terbuka.

Widi, Restu Kartiko. Asas metodologi Penelitian : Sebuah Pengenalan Dan Penuntun Langkah Demi Langkah Pelaksanaan Penelitian. Yogyakarta : Graha Ilmu, 2010.

Sugyono. Penelitian Pendidikan : Pendekatan Kuantitatif, Kualitatif dan $R \& D$. Bandung: Penerbit Alfabeta, 2012.

\section{Sumber Internet}

.http://portal.unesco.org/ci/en/ev.php-URL_ID=13366\&URL_DO=DO_TO PIC\&URL_SECTION=201.html (portal UNESCO untuk Piagam Pelestarian Pusaka Digital), diakses pada tanggal tanggal 1 April 2019.

Daryono, Preservasi Perpustakaan Digital(Kelebihan Dan Kekurangan Cara Preseravasi Digital), dalam http://daryono.staff.uns.ac.id/2011/12/08/preservasi-perpustakaan-digital-kel ebihan-dan-kekurangan-cara-preseravasi-digital-4/, diakses pada, tanggal 1 April 2019.

Elvina, Irma. Mengapa koleksi digital harus dipreservasi?, dalam http://irma.staff.ipb.ac.id/2010/04/07/ diakses pada hari Sabtu, tanggal 16 Mei 201

Sulendra, Wahyu Dona Pasa. Alih Media digital Bahan Pustaka, dalam https://docplayer.info/192736-Alih-media-digital-bahan-pustaka-oleh-wahy u-dona-pasa-sulendra-s-ip.html di akses pada hari rabu, tanggal 7 April 2019

http://digilib.pnri.go.id diakses pada, tanggal 3 April 2019

http://www. perpusnas.go.id diakses pada, tanggal 3 April 2019

http://www.badanperpusda-diy.go.id diakses pada, tanggal 1 April 2019 
JADWAL PENELITIAN

\begin{tabular}{|c|c|c|c|c|c|c|c|c|c|c|c|c|c|c|c|c|c|c|c|c|c|}
\hline \multirow{2}{*}{$\begin{array}{l}\mathbf{N} \\
\text { o. }\end{array}$} & \multirow{2}{*}{$\begin{array}{c}\text { Nama } \\
\text { Kegiatan }\end{array}$} & \multicolumn{2}{|c|}{$\begin{array}{l}\text { April } \\
2019 \\
\end{array}$} & \multicolumn{4}{|c|}{ Juni 2019} & \multicolumn{4}{|c|}{ Juli 2019} & \multicolumn{4}{|c|}{ Agustus 2019} & \multicolumn{4}{|c|}{$\begin{array}{c}\text { September } \\
2019\end{array}$} & \multicolumn{2}{|c|}{$\begin{array}{l}\text { Okt. } \\
2019\end{array}$} \\
\hline & & I & $\begin{array}{l}\mathrm{I} \\
\mathrm{I} \\
\end{array}$ & I & \begin{tabular}{|l|}
$\mathrm{I}$ \\
$\mathrm{I}$ \\
\end{tabular} & $\begin{array}{c}\text { II } \\
\text { I }\end{array}$ & $\begin{array}{l}\mathrm{I} \\
\mathrm{V}\end{array}$ & I & $\begin{array}{l}\mathrm{I} \\
\mathrm{I}\end{array}$ & $\begin{array}{c}\text { II } \\
\text { I }\end{array}$ & $\begin{array}{l}\mathrm{I} \\
\mathrm{V} \\
\end{array}$ & I & $\begin{array}{l}\mathrm{I} \\
\mathrm{I}\end{array}$ & $\begin{array}{c}\text { II } \\
\text { I }\end{array}$ & $\begin{array}{l}\text { I } \\
\text { V }\end{array}$ & I & II & $\begin{array}{c}\text { II } \\
\text { I }\end{array}$ & $\begin{array}{l}\mathrm{I} \\
\mathrm{V}\end{array}$ & I & II \\
\hline 1. & $\begin{array}{l}\text { Penyusuna } \\
\mathrm{n} \text { proposal }\end{array}$ & & & & & & & & & & & & & & & & & & & & \\
\hline 2. & $\begin{array}{l}\text { Pendataan } \\
\text { Koleksi } \\
\text { Kaset } \\
\text { Video } \\
\text { Langka }\end{array}$ & & & & & & & & 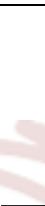 & & & & & & & & & & & & \\
\hline 4. & $\begin{array}{l}\text { Cek } \\
\text { Bahan } \\
\text { Yang akan } \\
\text { di preser- } \\
\text { vasi }\end{array}$ & & & & & & & & & 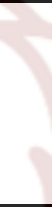 & & & & & e & & & & & & \\
\hline 5. & $\begin{array}{l}\text { Alih Media } \\
\text { Kaset } \\
\text { Video }\end{array}$ & & & & & & & & & & & & & & & & & & & & \\
\hline 6. & $\begin{array}{l}\text { Pengumpul } \\
\text { an data } \\
\text { penelitian }\end{array}$ & & & & & & & & & & & & 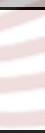 & 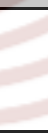 & 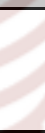 & & & & & & \\
\hline 7. & $\begin{array}{l}\text { Analisis } \\
\text { data }\end{array}$ & & & & & & & & & 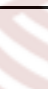 & 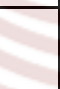 & & 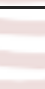 & 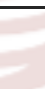 & 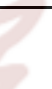 & & & & & & \\
\hline 8 & $\begin{array}{l}\text { Penyempur } \\
\text { naan } \\
\text { Laporan }\end{array}$ & & & & & & & & & & & & & & & & 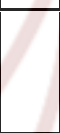 & & & & \\
\hline & & & & & & & & & & & & & & 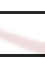 & & & E & $\bar{C}$ & & & \\
\hline
\end{tabular}

Tabel 4. Jadwal Penelitian 


\section{Lampiran 1}

Justifikasi Anggaran Penelitian Pemula

\begin{tabular}{|c|c|c|c|c|c|}
\hline Nomor & Jenis & \multicolumn{2}{|c|}{ Volume } & Tarip & Jumlah \\
\hline 1 & 2 & \multicolumn{2}{|c|}{3} & 4 & 5 \\
\hline \multirow[t]{4}{*}{1} & Belanja Uang Honor & & & & \\
\hline & Pembantu Peneliti & 24 & OJ & 25,000 & 600,000 \\
\hline & Narasumber & 2 & $\mathrm{OK}$ & 500,000 & $1,000,000$ \\
\hline & Pengolah Data & 1 & $\mathrm{OK}$ & $1,200,000$ & $1,200,000$ \\
\hline \multicolumn{5}{|r|}{ Jumlah } & $2,800,000$ \\
\hline \multirow[t]{15}{*}{2} & Bahan Habis Pakai dan Peralatan & & & & \\
\hline & a. Bahan habis pakai & & & & \\
\hline & Kertas Folio A4 80 grm & 4 & $\operatorname{Rim}$ & 43,000 & 172,000 \\
\hline & Blog note & 10 & $\mathrm{BH}$ & 7,000 & 70,000 \\
\hline & Bolpoint Snowman V.5 & 1 & Pak & 40,000 & 40,000 \\
\hline & Tinta Refill (hitam) & 3 & $\mathrm{BH}$ & 75,000 & 225,000 \\
\hline & Tinta Refill (warna) & 3 & $\mathrm{BH}$ & 65,000 & 195,000 \\
\hline & DVD Blank & 150 & $\mathrm{BH}$ & 3,000 & 450,000 \\
\hline & Box CD & 150 & $\mathrm{BH}$ & 2,000 & 300,000 \\
\hline & Kertas Label CD & 3 & Pak & 30,000 & 90,000 \\
\hline & Kertas Cover CD & 1 & Pak & 35,000 & 35,000 \\
\hline & M. Wireles Robot & 1 & $\mathrm{BH}$ & 83,000 & 83,000 \\
\hline & Capture Mygiga Capit & 1 & $\mathrm{BH}$ & 300,000 & 300,000 \\
\hline & Hardisk ekternal 1 Tera & 1 & $\mathrm{BH}$ & $1,250,000$ & $1,250,000$ \\
\hline & $\bar{x}$ & - & 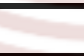 & Jumlah & $3,210,000$ \\
\hline \multirow[t]{4}{*}{3} & Perjalanan & - & 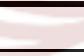 & 2 & \\
\hline & $\begin{array}{l}\text { Dalam kota Solo pustakawan } 1 \\
\text { org x } 30 \text { hari }\end{array}$ & 30 & $\mathrm{OH}$ & 50,000 & $1,500,000$ \\
\hline & $\begin{array}{l}\text { Dalam kota Solo, koordinasi } 2 \mathrm{x} \\
10 \text { hari }\end{array}$ & 10 & $\mathrm{OH}$ & 60,000 & 600,000 \\
\hline & $\begin{array}{l}\text { Dalam kota Solo, sewa mobil } 1 \\
\text { hari }\end{array}$ & 1 & $\mathrm{OH}$ & 300,000 & 300,000 \\
\hline & 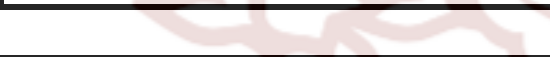 & . & & Jumlah & $2,400,000$ \\
\hline 4 & 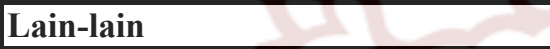 & 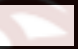 & & +0 & \\
\hline \multirow[t]{2}{*}{$a$} & Konsumsi & 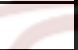 & & 3 & \\
\hline & Makan 1 org x $30 \mathrm{hr}$ & 30 & $\mathrm{OH}$ & 25,000 & 750,000 \\
\hline \multirow[t]{2}{*}{$\vec{b}$} & Persewaan & & & & \\
\hline & Sewa Player Video $8,1 \times 10$ hari & 10 & $\mathrm{OH}$ & 50,000 & 500,000 \\
\hline \multirow[t]{2}{*}{$c$} & Laporan & & & & \\
\hline & Susun dan Penggandaan laporan & 1 & $\mathrm{Pkt}$ & 340,000 & 340,000 \\
\hline \multicolumn{5}{|r|}{ Jumlah } & $1,590,000$ \\
\hline & & & & $\overline{\text { TOTAL }}$ & $\overline{10,000,000}$ \\
\hline
\end{tabular}




\section{PUSAT PENELITIAN}

J1. Ki Hajar Dewantara No. 19 Kentingan, Jebres, Surakarta 57126 Telepon 0271.647658,

\section{SURAT PERNYATAAN PENELITI PEMULA}

Yang bertanda tangan di bawah ini :

Nama

: Eko Sulistyo, S.Sn.

NIP

: 197211182006041001

Pangkat/Golongan

: Penata Tingkat I, III /d

Jabatan Fungsional

: Pustakawan Muda

Dengan ini menyatakan bahwa proposal penelitian pemula saya dengan judul : Preservasi Koleksi Kaset Video Langka ke Dalam Bentuk Digital Melalui Proses Alih Media (Studi Kasus di UPT Perpustakaan ISI Surakarta) yang diusulkan dalam skim Penelitian Pemula untuk tahun anggaran: 2019 bersifat original dan belum pernah dibiayai oleh lembaga/sumber dana lain.

Bilamana di kemudian hari ditemukan tidak kesesuaian dengan pernyataan ini, maka saya bersedia dituntut dan diproses sesuai dengan ketentuan yang berlaku dan mengembalikan seluruh biaya penelitian pemula yang sudah diterima ke kas negara. benarnya.

Demikian pernyataan ini dibuat dengan sesungguhnya dan sebenarSurakarta, 30 Oktober 2019

Mengetahui

Kepala Pusat Penelitian

Yang menyatakan

Satriana Didiek Isnanta, M.Sn.

NIP. 197212212005011002
Eko Sulistyo, S.Sn

NIP 197211182006041001 


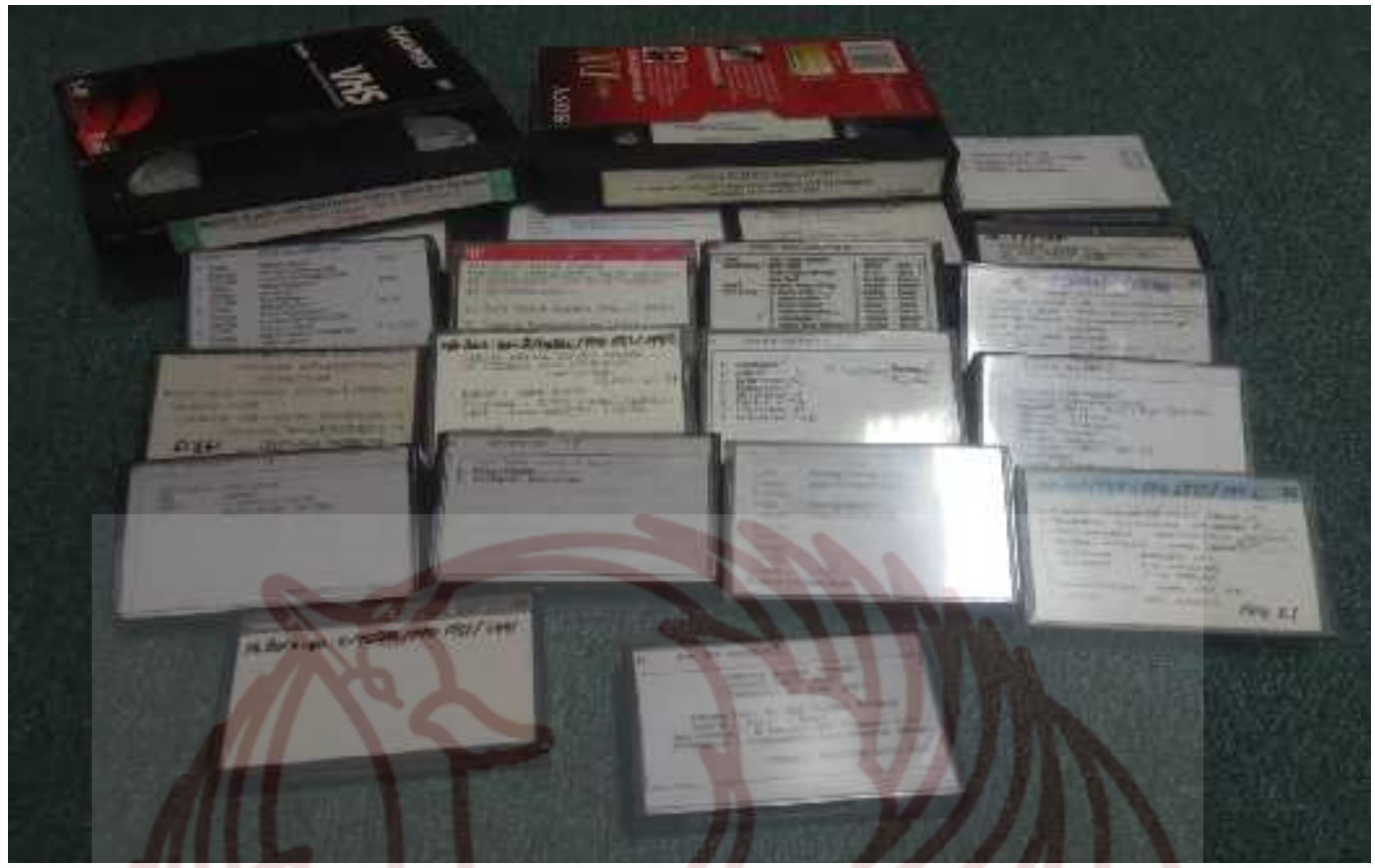

Gb 1. Kaset Video yang di Preservasi

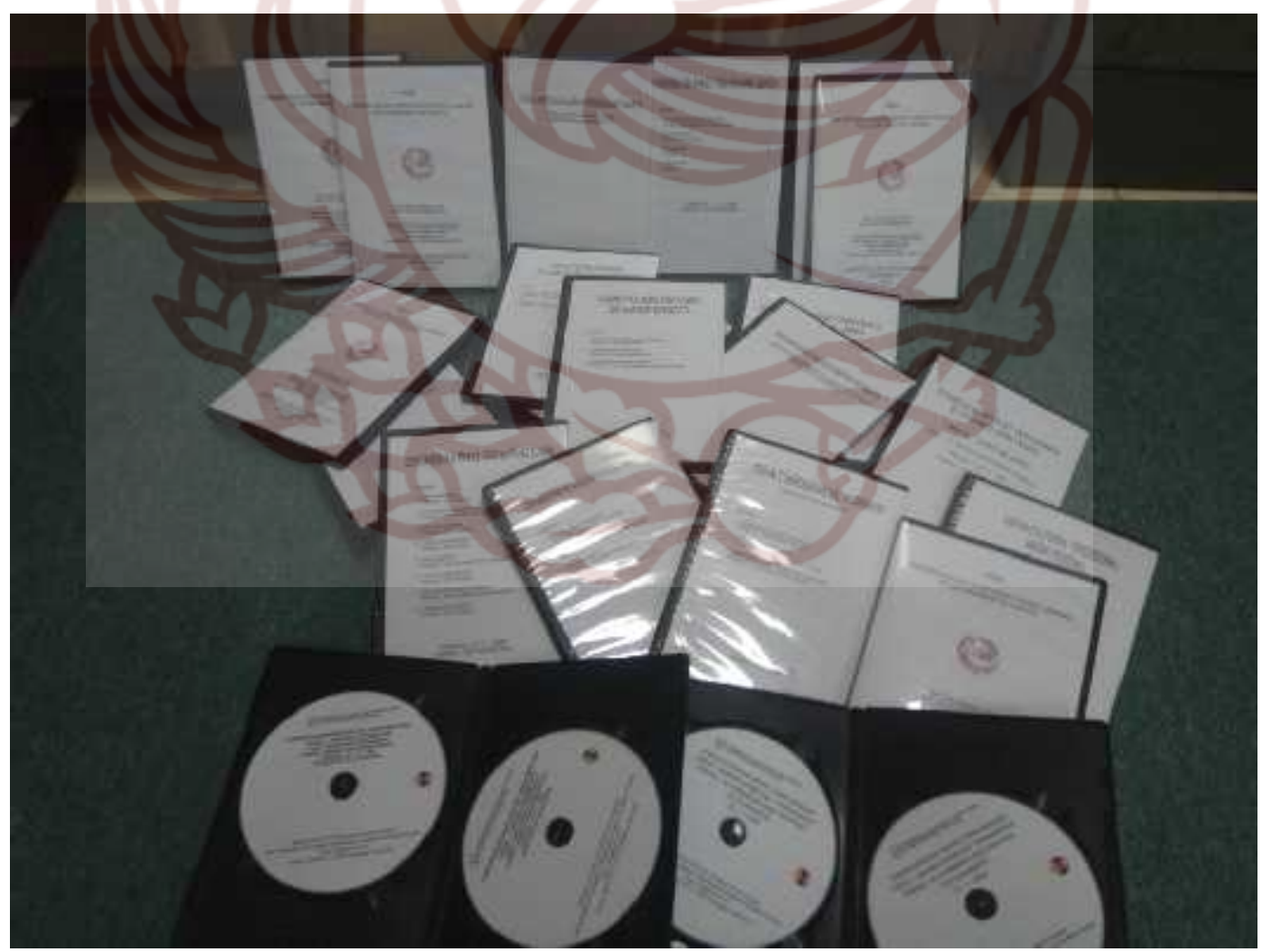

Gb 2. Hasil Video Yang di Preservasi 


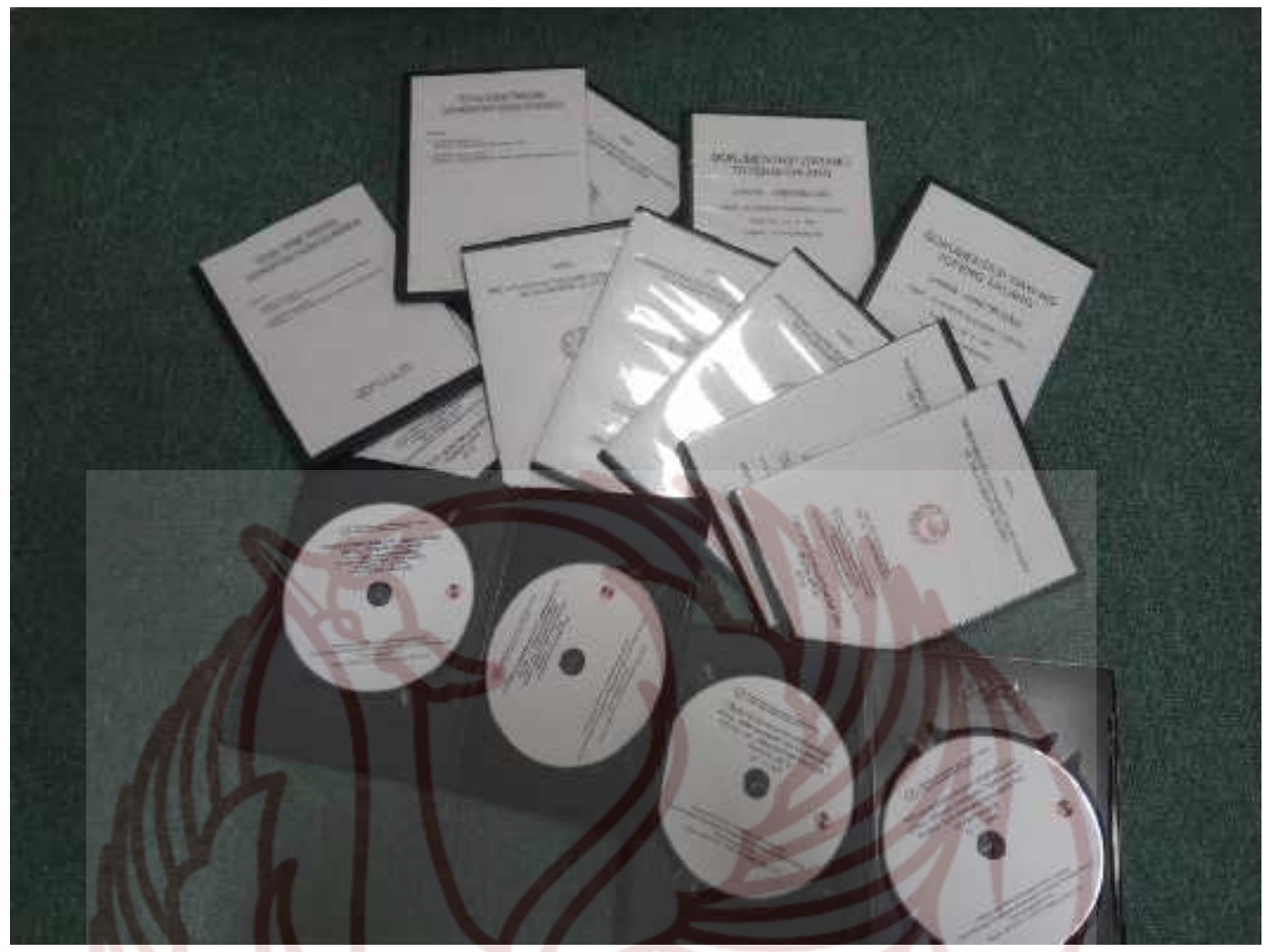

Gb 3. Hasil Video yang di Preservasi

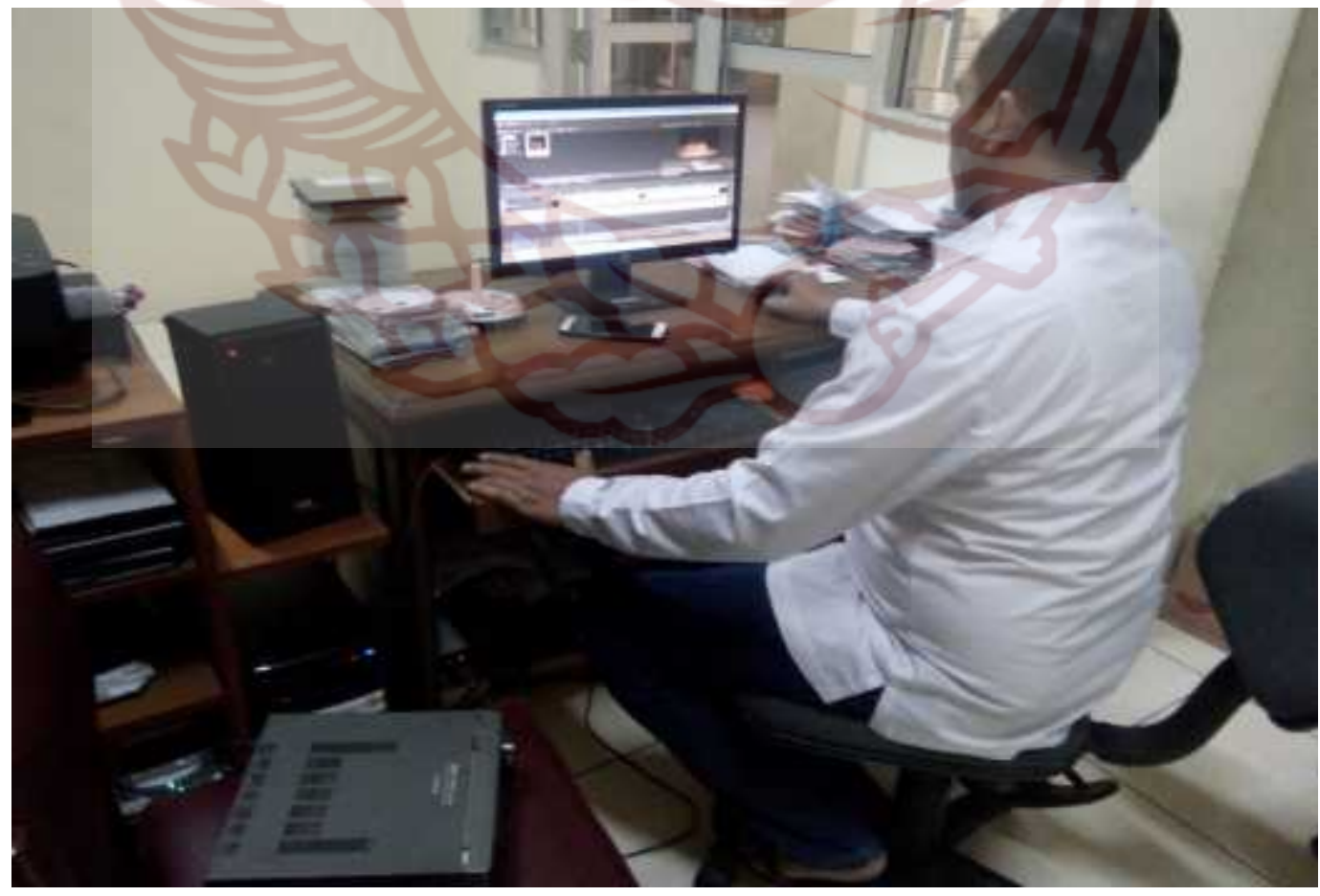

Gb 4. Petugas Sedang Mengolah Video 


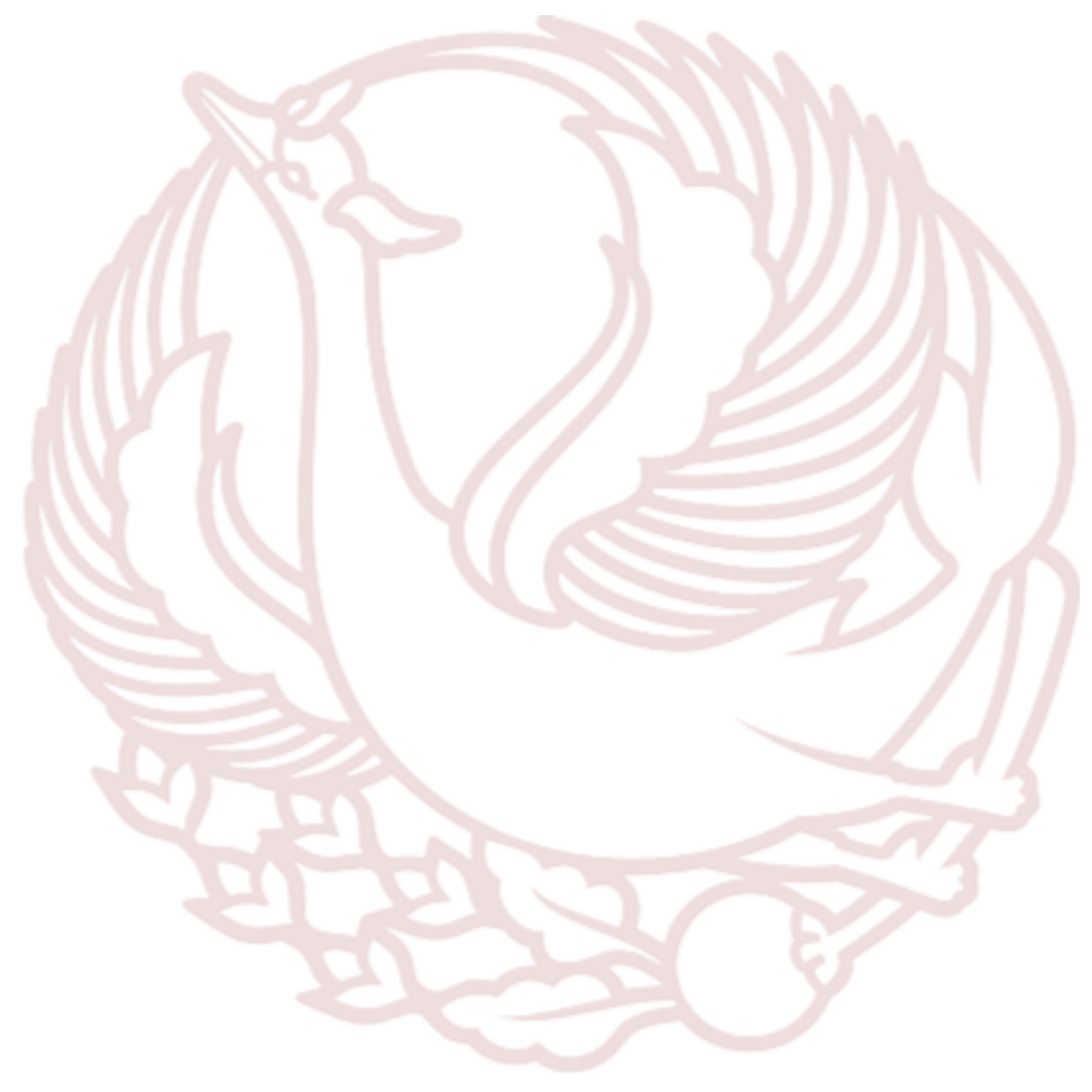

